Portland State University

PDXScholar

1984

\title{
Quaternary volcanology of the West Crater-Soda Peaks area, southern Washington Cascade Range
}

David R. Polivka

Portland State University

Follow this and additional works at: https://pdxscholar.library.pdx.edu/open_access_etds

Part of the Geology Commons, Stratigraphy Commons, and the Volcanology Commons Let us know how access to this document benefits you.

\section{Recommended Citation}

Polivka, David R., "Quaternary volcanology of the West Crater-Soda Peaks area, southern Washington Cascade Range" (1984). Dissertations and Theses. Paper 3396.

https://doi.org/10.15760/etd.5279

This Thesis is brought to you for free and open access. It has been accepted for inclusion in Dissertations and Theses by an authorized administrator of PDXScholar. Please contact us if we can make this document more accessible: pdxscholar@pdx.edu. 
AN ABSTRACT OF THE THESIS OF DAVID R. POLIVKA FOR the Master of Science in Geology presented June 4, 1984.

Title: Quaternary Volcanology of the West Crater-Soda Peaks Area, Southern Washington Cascade Range

APPROVED BY MEMBERS OF THE THESIS COMMITTEE:

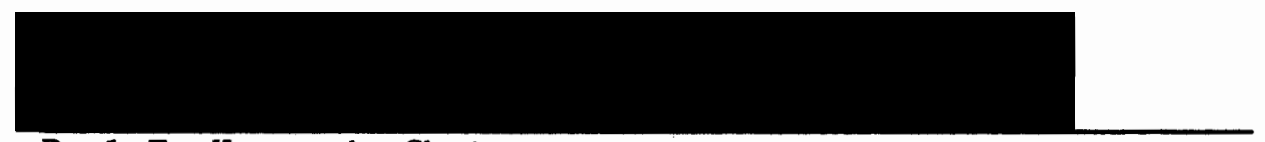

Paul E. Hammond, Chairman
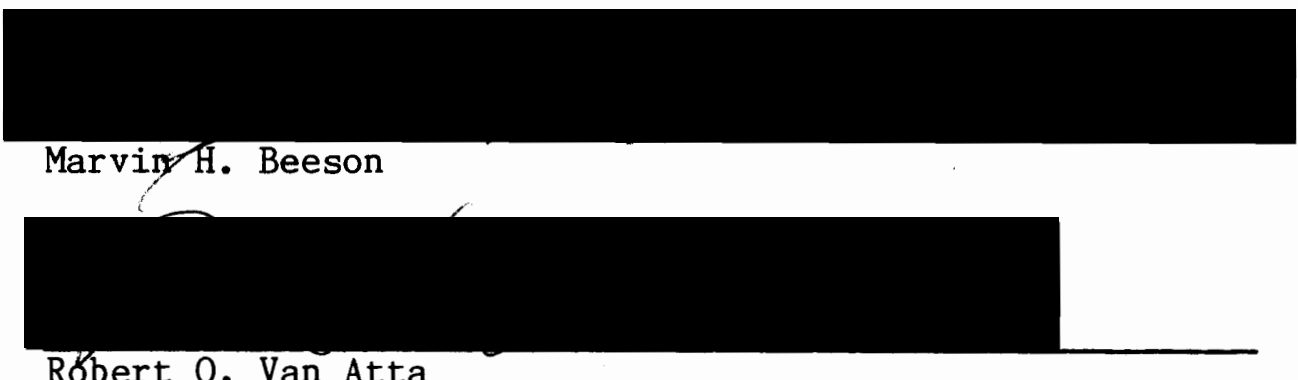

2

The West Crater-Soda Peaks area covering about $100 \mathrm{~km}$ is located $35 \mathrm{~km}$ southeast of Mount St. Helens in southern Washington State. It is one of several Quaternary monogenetic High Cascade volcanic centers overlying the Ohanapecosh Formation of the Western Cascade Group and interstratified glacial till. 
These volcanic centers are the most westerly of the range. Fifteen rock units are differentiated ranging from surficial deposits to basaltic and andesitic lava flows to volcaniclastic sedimentary rocks and diorite intrusions. The 36 m. y. to $28 \mathrm{~m}$. y. old Ohanapecosh Formation underlies the entire map area and is composed of interstratified basaltic lava flows and volcaniclastic sedimentary rocks. Numerous Tertiary basaltic and andesitic dikes, plugs, and sills intrude the Ohanapecosh Formation. Thirteen High Cascade basaltic to andesitic volcanic units are defined in the area, ranging in age from 360,000 years for the Basalt of Soda Peaks to no younger than 2,000 years for the fresh blocky andesites of West Crater. Except for the andesites of South Soda Peaks, Bare Mountain and West Crater, the units occur as scattered lava flows in single flow units. The volcanic features are highlighted by the occurrence of a $60 \mathrm{~m}-$ deep, 300 m-wide explosion crater at Bare Mountain and a $54 \mathrm{~m}-$ high andesite dome followed by two andesite lava flows at West Crater.

The Ohanapecosh strata are deformed into a series of broad shallow folds of Tertiary age plunging to the northwest. Although the area lies along the southward projection of the Mount St. Helens seismic zone, no large scale faulting was observed. The density of the volcanic centers, 13 centers within 2 less than $100 \mathrm{~km}$, may indicate underlying zones of weakness. The intrusions are aligned chiefly northwest and northeast, 
parallel to the two regional structural trends in the Cascade Range of southern Washington.

The High Cascade rocks are high-alumina calc-alkaline basalts and andesites. On the basis of major and trace element chemistry, the rock units are divided into four chemical groups, the Soda Peaks chemical group, the Sister Rocks chemical group, the Bare Mountain chemical group, and the West Crater chemical group. The volcanic rocks of the map area are probably the products of several magmatic processes, differentiation of unrelated sources, or the partial melting of a heterogeneous source. 
QUATERNARY VOLCANOLOGY OF THE WEST

CRATER-SODA PEAKS AREA, SOUTHERN

WASHINGTON CASCADE RANGE

by

David R. Polivka

A thesis submitted in partial fulfillment

of the requirements for the degree of

\section{MASTER OF SCIENCE \\ in \\ GEOLOGY}

Portland State University 
To the Office of Graduate Studies and Research:

The members of the committee approve the thesis of David R. Polivka presented June 4, 1984.

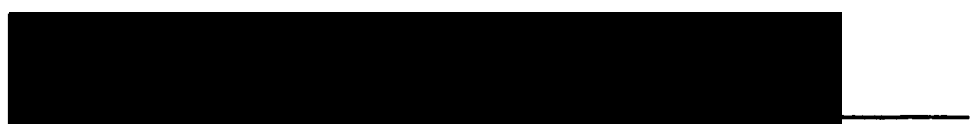

Paul E. Hammond, Chairman

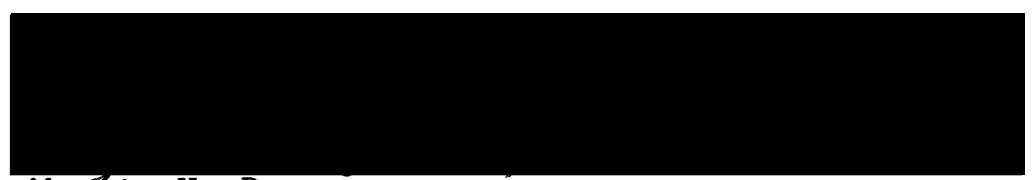

Maprin $\mathrm{H}$. Beeson

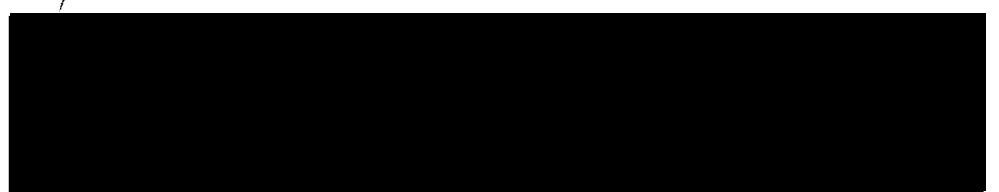

R6bert 0. Van Atta

APPROVED
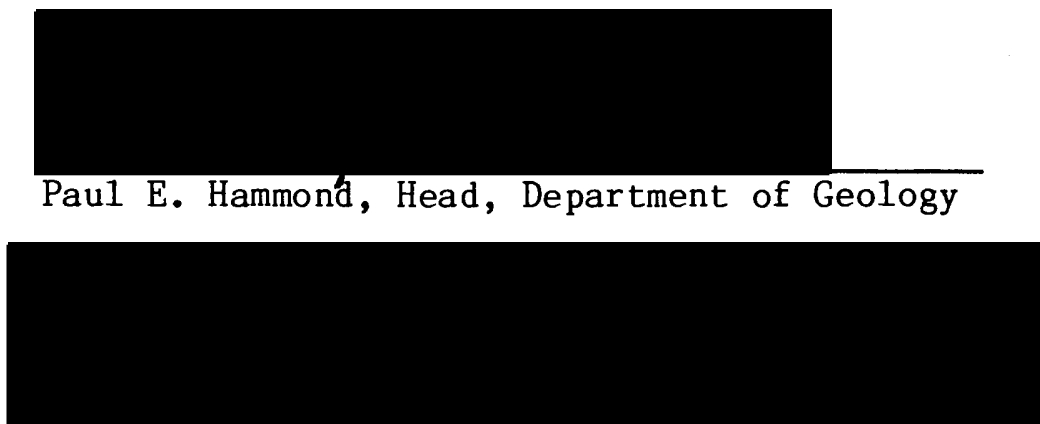

Jim . Heath, Dean of Graduate Studies and Research 


\section{ACKNOWLEDGMENTS}

I wish to thank Dr. Paul E. Hammond, Associate Professor of Geology at Portland State University under whose guidance and encouragement the study was undertaken.

I also wish to acknowledge the contributions of the following people and organizations without whose help this study could never been undertaken and completed.

A base map, aerial photographs and thin-sections were provided by the State of Washington Department of Natural Resources. Partial support of field and laboratory expenses was provided by the Mazamas and the Northwest Scientific Association. The United Telephone Company graciously permitted the use of their IBM 5100 computer in the initial plotting of the chemical analyses. I also wish to acknowledge the help of the faculty, staff, and fellow students in the Department of Geology at Portland State University, and my parents and in-laws for the encouragement and financial support during the project.

Last but not least I wish to acknowledge my wife Dianne who had to live with me during my joys and frustrations. 
LIST OF TABLES $\ldots \ldots \ldots \ldots \ldots \ldots \ldots \ldots \ldots \ldots \ldots \ldots \ldots \ldots \ldots \ldots$

LIST OF FIGURES $\ldots \ldots \ldots \ldots \ldots \ldots \ldots \ldots \ldots \ldots \ldots \ldots$ vii

CHAPTER

I INTRODUCTION $\ldots \ldots \ldots \ldots \ldots \ldots \ldots \ldots \ldots \ldots \ldots \ldots \ldots$

Significance $. \ldots \ldots \ldots \ldots \ldots \ldots \ldots \ldots \ldots, 1$

Purpose $\ldots \ldots \ldots \ldots \ldots \ldots \ldots \ldots \ldots \ldots \ldots \ldots \ldots \ldots$

Location $\ldots \ldots \ldots \ldots \ldots \ldots \ldots \ldots \ldots \ldots \ldots \ldots$

Method of investigation $. . \ldots \ldots \ldots \ldots \ldots, 2$

II REGIONAL GEOLOGY $\ldots \ldots \ldots \ldots \ldots \ldots \ldots \ldots \ldots \ldots, 5$

Western Cascade group

High Cascade group

Structure

III $\quad$ ROCK UNITS $\ldots \ldots \ldots \ldots \ldots \ldots \ldots \ldots \ldots \ldots \ldots \ldots, 11$

Ohanapecosh Formation .............. 13

Tertiary intrusions ............... 14

High Cascade volcanic rocks .......... 15

Basalt of Soda Peaks ........... 16

Basalt of Sister Rocks .......... 20

Andesite of Calamity Creek ........ 22

Andesite of Siouxon Creek ........ 22

Andesite of Timbered Peak ........ 23 
CHAPTER

PAGE

Andesites of South Soda Peaks ...... 24

Andesites of Bare Mountain ....... 26

Andesite of Chinook Creek ........ 27

Andesite of Puny Creek .......... 28

Andesite scorica cone of Hackamore Creek .................... 29

Bare Mountain tephra deposits ..... 30

Andesites of West Crater ......... 31

Surficial deposits ............. 34

IV $\quad$ STRUCTURE ....................... 36

V GEOCHEMISTRY ........................ 38

VI SUMMARY ............................. 54

REFERENCES CITED ......................... 58

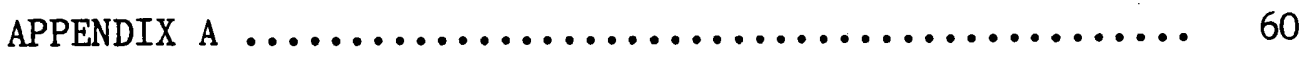

APPENDIX $\mathrm{B} \ldots \ldots \ldots \ldots \ldots \ldots \ldots \ldots \ldots \ldots \ldots \ldots \ldots \ldots \ldots \ldots \ldots \ldots \ldots$

APPENDIX $\mathrm{C} \ldots \ldots \ldots \ldots \ldots \ldots \ldots \ldots \ldots \ldots \ldots \ldots \ldots \ldots \ldots \ldots \ldots \ldots$

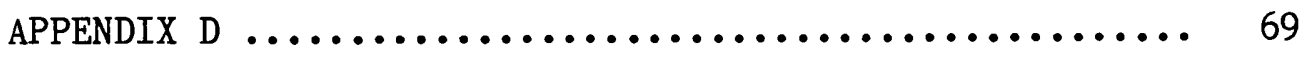

APPENDIX E $\ldots \ldots \ldots \ldots \ldots \ldots \ldots \ldots \ldots \ldots \ldots \ldots \ldots \ldots \ldots \ldots \ldots \ldots \ldots$

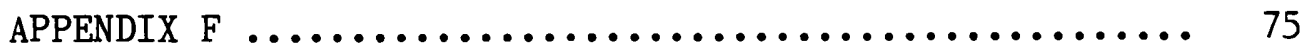




\section{LIST OF TABLES}

\section{TABLE}

PAGE

I Age dates $\ldots \ldots \ldots \ldots \ldots \ldots \ldots \ldots \ldots \ldots \ldots \ldots \ldots \ldots$

II Criteria for stratigraphic determination ..... 18

III Volume of High Cascade lava flows ........... 19

IV Summary of geochemical groups ............ 52

$\mathrm{V}$ Precision of $\mathrm{XRF}$ analysis .............. 77 
LIST OF FIGURES

FIGURE

PAGE

1. Location map $\ldots \ldots \ldots \ldots \ldots \ldots \ldots \ldots \ldots \ldots \ldots, 3$

2. Generalized regional map $\ldots \ldots \ldots \ldots \ldots \ldots \ldots \ldots \ldots 6$

3. Regional stratigraphy $\ldots \ldots \ldots \ldots \ldots \ldots \ldots \ldots \ldots, 8$

4. Composite stratigraphic column of map units ..... 12

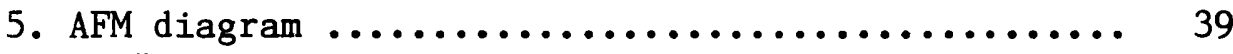

6. $\mathrm{FeO} / \mathrm{MgO}$ vs $\mathrm{SiO}$ variation diagram ........... 40

7. Th-Ta-Hf diagram $. . \ldots \ldots \ldots \ldots \ldots \ldots \ldots \ldots \ldots . . \ldots 4$

8. Si0 variation diagrams $\ldots \ldots \ldots \ldots \ldots \ldots \ldots \ldots, 42$

9. $\mathrm{MgO}$ variation diagrams $\ldots \ldots \ldots \ldots \ldots \ldots \ldots \ldots . \ldots, 43$

10. Trace element variation diagrams $\ldots \ldots \ldots \ldots \ldots \ldots, 44$

11. Hf and La vs $\mathrm{MgO}$ variation diagrams $\ldots \ldots \ldots \ldots \ldots .45$

12. Rock/chondrite normalized rare earth elements .... 47

13. Age vs $\mathrm{SiO}, \mathrm{FeO}, \mathrm{Na}, \mathrm{K}, \mathrm{P}_{2} \mathrm{O}_{2}$ and $\mathrm{La} / \mathrm{Sm} . . . . . .449$ 
CHAPTER I

INTRODUCTION

\section{SIGNIFICANCE}

Reconnaissance mapping of the $100 \mathrm{~km}^{2}$ study area, $35 \mathrm{~km}$ southeast of Mount St. Helens (Figure 1; Wise, 1970; Hammond, 1980) had earlier indicated a cluster of four High Cascade volcanoes overlying the Ohanapecosh and Stevens Ridge Formations of Tertiary age. Further mapping revealed that the area contained many monogenetic volcanic centers interstratified with glacial till and overlying the Ohanapecosh Formation. The centers are considered monogenetic in that the scoria cones and lava flows were produced in a single eruptive cycle. The volcanic centers range in age from 360,000 years to no younger than 2,000 years. Except for Mount St. Helens these centers form the most westerly group of High Cascade volcanic rocks, approximately $25 \mathrm{~km}$ west of the crest of the range. The study obtains basic data which will serve to better define the younger volcanism of the Cascade Range and the Pacific Northwest.

PURPOSE

The specific objectives of the study were: 1) to prepare a detailed reconnaissance geologic map on the scale of $1: 24,000$, of a relatively unknown area from which the sequence of volcanism 
and volumes were to be interpreted; and 2) to describe the volcanic features in the area.

\section{LOCATION}

The study area is located in Skamania County of southwestern Washington, $35 \mathrm{~km}$ southeast of Mount St. Helens (Figure 1). It lies in the Gifford Pinchot National Forest and is accessible from the southeast by Forest Service Roads: 30 (Wind River Highway), 43 and 54. The area is accessible from the west by either Forest Service Roads 54 or 42 . The eastern portion of the map area is wilderness and is traversed by several hiking trails.

Topographic relief in the area is approximately 1,900 feet; elevations range from 2,400 feet to nearly 4,300 feet above mean sea level. Widespread glaciation has created a rugged topography consisting of many steep-sided glacial valleys and cirques. Approximately 50 percent of the area has been extensively clearcut.

\section{METHOD OF INVESTIGATION}

Approximately fifteen weeks, during the summer of 1982 were spent in the field mapping and collecting samples. About $56 \mathrm{~km}$ were mapped in detail on a base map of scale 1:24,000. The 2

remainder of the $100 \mathrm{~km}$ area was mapped in reconnaissance. Outcrops were followed along all roads and some creek beds. Where outcrops existed, contacts of the individual units on the 


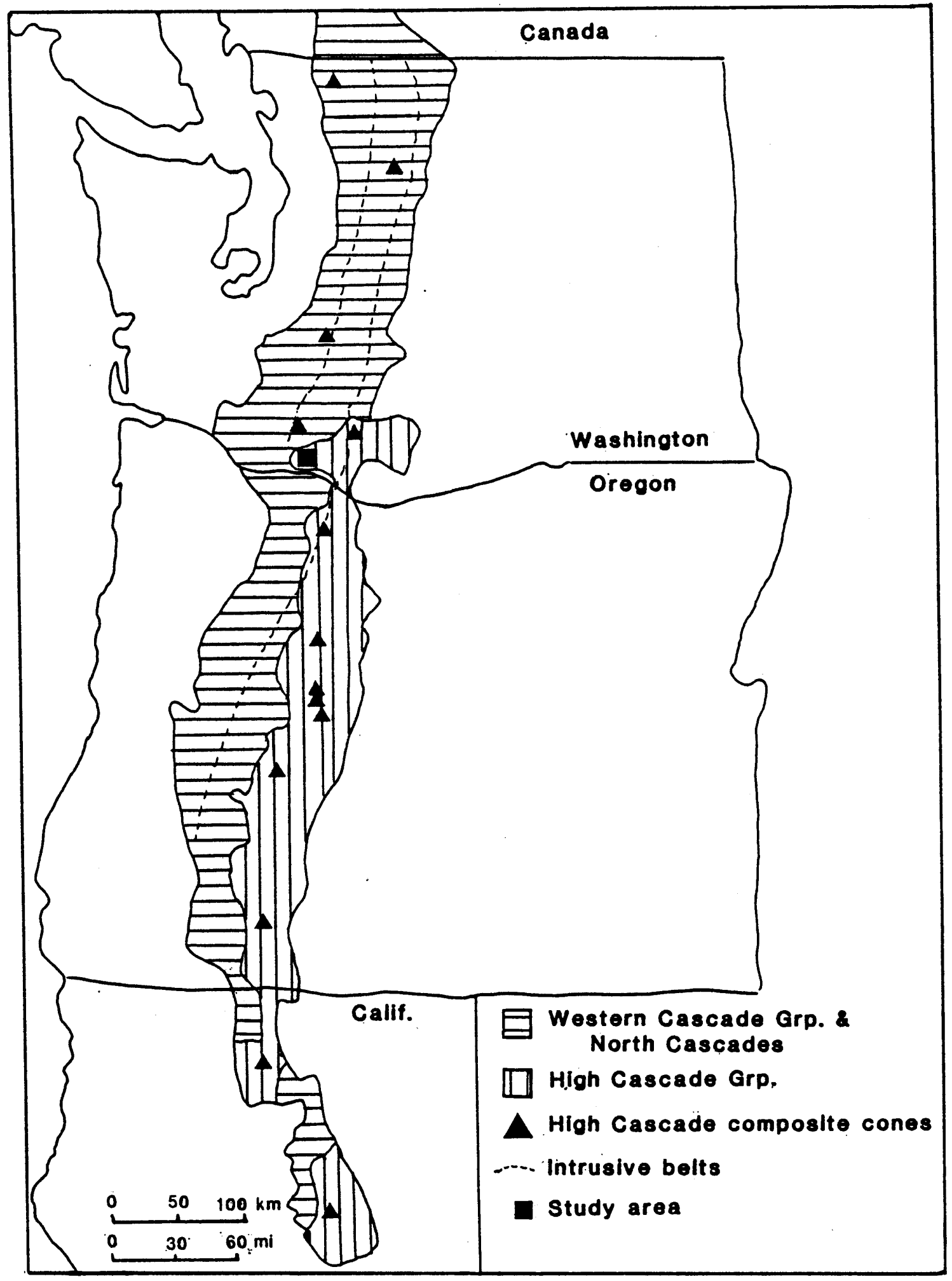

Figure 1. Index map showing the location of the study area. 
surface were traced. Reconnaissance mapping was conducted in the eastern portion of the map area along trails. In inaccessible areas, mapping was conducted on aerial photographs at the scale of 1:24,000. The thickness of scoria was determined by digging pits to the base of the scoria.

Representative samples of each rock unit were taken for petrographic and chemical analyses. The $\mathrm{K}-\mathrm{Ar}$ age dating was completed by R. A. Duncan of the Oregon State University School 14

of Oceanography; $C$ dates were determined by F. N. Fairhall of the Department of Chemistry at the University of Washington and by Rubin Meyers of the United States Geological Survey, Reston Virginia. Twenty-three whole rock samples were submitted to Peter Hooper of the Department of Geology at Washington State University for major element analysis by $x$-ray fluorescence. Four whole rock major element analyses were run by A. N. Baxter of the city of London Polytechnic. Nineteen of the whole rock samples analyzed for major elements were analyzed for trace elements by the author using the INAA method. Irradiation was done using a TRIGA Mark I research reactor at Reed College. The samples were counted at Portland State University using a Ge-Li detector and a Tracor Northern analyzer.

Petrographic analysis of the rock units was undertaken using the facilities of Portland State University. Thin-sections were prepared by the Division of Geology and Earth Resources of the Department of Natural Resources of the State of Washington. 


\section{REGIONAL GEOLOGY}

The Cascade Range of southern Washington, lies just north of the middle of the 600 mile-long north-south trending Eocene (50 m. y.) to Holocene basaltic to dacitic volcanic belt extending from Mount Garibaldi in British Columbia to Mount Lassen in northern California (Figure 2). The range has been studied by many people over many years; a bibliography is given in Hammond $(1979,1980)$.

This arc-type volcanic belt is considered to be associated with subduction along the contact of the Juan de Fuca Plate with the North American Plate. The northern Cascade Range, bounded on the south by the 01ympic-Wallowa Lineament (OWL), consists primarily of pre-Cenozoic sedimentary, metamorphic, and plutonic rocks with some Tertiary volcanic rocks and subvolcanic plutons. The southern Cascade Range of Washington is composed entirely of Cenozoic volcanic and intrusive rocks.

Based on age and rock type, the Cascade Range has been divided into two groups, the Western Cascade Group (50 to $5 \mathrm{~m}$. y. ago) and the High Cascade Group ( $5 \mathrm{~m}$. y. ago to Present). The Western Cascade Group consists chiefly of volcaniclastic sedimentary rocks, calc-alkaline basalts to rhyodacites in the form of lava flows, and pyroclastic falls and flows, 5 to $8.5 \mathrm{~km}$ thick. The entire group has been extensively intruded and 


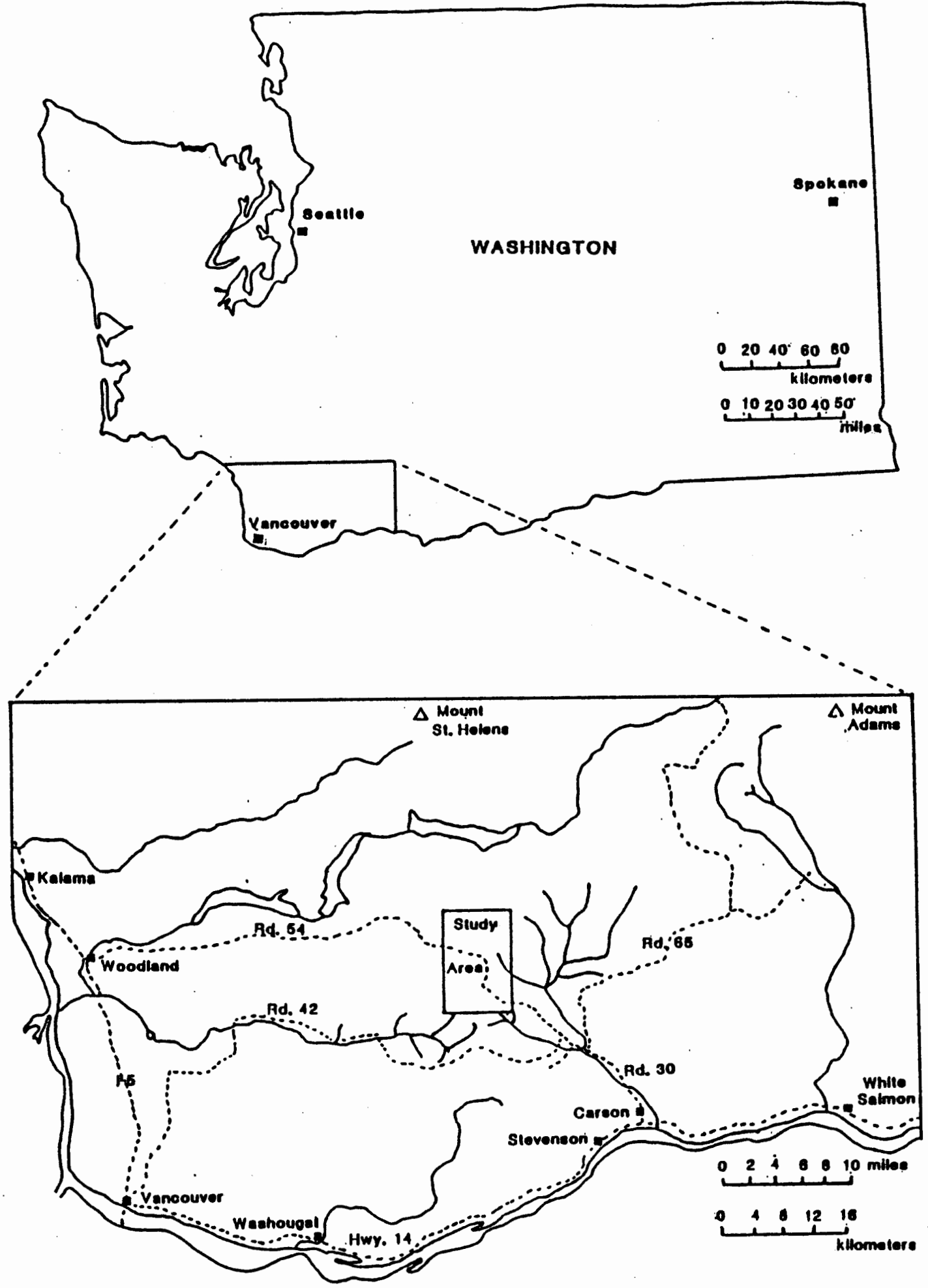

Figure 2. Generalized regional map showing the Cascade Range (Modified after Hammond, 1979). 
slightly but pervasively metamorphosed to zeolite facies (Wise, 1970). The rocks of the High Cascade Group range from olivine basalt to dacite. Except for local area of normal faulting and hydrothermal alteration, the unconformably superposed High Cascade Group is unaltered and generally structurally undeformed. In southern Washington, the Western Cascade Group is stratigraphically divided into three subgroups (Figure 3) with the middle subgroup being the most distinctive. The upper and lower subgroups are therefore assigned to their position relative to the middle subgroup. The lower subgroup, the Ohanapecosh Formation ( 1.5 to $5 \mathrm{~km}$ thick), consists of volcaniclastic and laharic breccias with interstratified andesitic, basaltic, and some silicic lava flows. This 50 to $30 \mathrm{~m}$. y. old unit, exposed chiefly on the west side of the range becomes richer in volcaniclastic beds eastward toward the crest.

The 0.5 to $3 \mathrm{~km}$ thick middle subgroup, the Stevens Ridge Formation, consists chiefly of interstratified pyroclastic flows and volcaniclastic sedimentary rocks and does not occur in the map area. It is interstratified with lava flows of andesite and basalt assigned to the Fifes Peak Formation (Figure 3). The age of the middle subgroup ranges from 30 to $15 \mathrm{~m}$. y. ago. Interbedding of the Eagle Creek Formation with the Columbia River basalts indicates that the middle subgroup was contemporaneous with early outpourings of Columbia River Basalt Group lavas.

Dacite and andesitic pyroclastic flows, mudflows, volcaniclastic sedimentary rocks and andesite lava flows comprise 


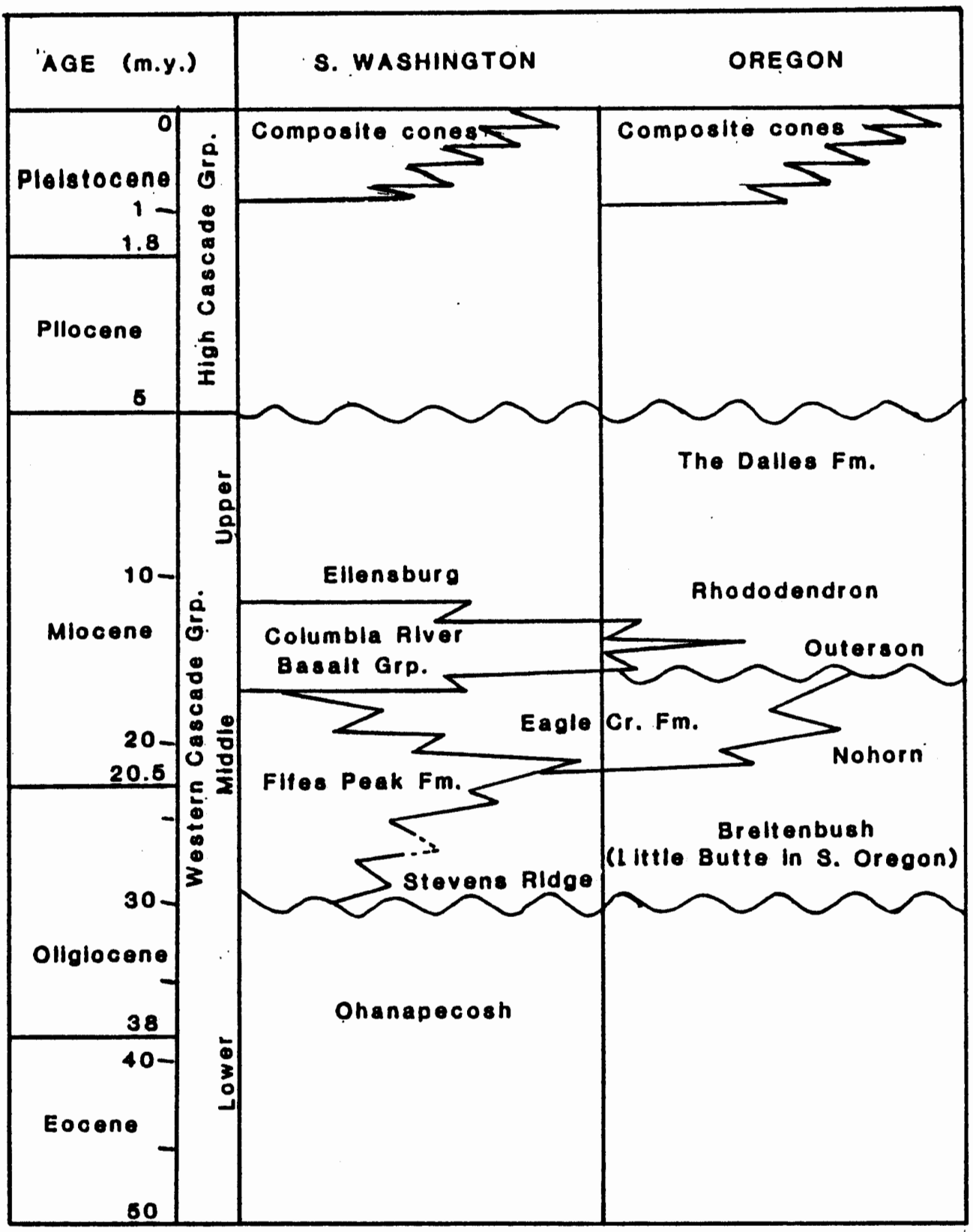

Figure 3. Regional Stratigraphy (Modified after Hammond, 1979). 
the 0.25 to $0.75 \mathrm{~km}$ thick upper subgroup of the Western Cascade Group. These rocks have been assigned to the Ellensburg and Rhododendron Formations. The upper subgroup is the most silicic of the three Western Cascade subgroups.

Comagmatic quartz diorite, granodiorite and less quartz monzonites and granites form many dikes, sills, plugs, and plutons intruding the Western Cascade Group. These intrusions are dated at 50 to $10 \mathrm{~m}$. y. and form two north-south belts (Figure 2).

The High Cascade Group consists mostly of high-alumina calc-alkaline basalts to dacites with minor olivine tholeiite basalts and basaltic andesites. The basalt is mainly the eruptive product of monogenetic cinder cones and shield volcanoes, while the andesite and dacite form the large polygenetic composite cones of the High Cascades. The High Cascade volcanic rocks range in age from $4.5 \mathrm{~m}$. y. to the Present usually forming a north-south belt with the greatest concentration south of the OWL. The high peaks are all less than 700,000 years old.

The Cascade Range has been glaciated several time during the Pleistocene. Till, numerous cirques and glacial valleys are common along the crest of the range and in the valleys. The most recent glaciation, called the Evans Creek Stade of the Fraser Glaciation, occurred 20,000 to 10,000 years ago (Crandell and Miller, 1974). 
The Western Cascade Group is folded and faulted while the High Cascade Group is generally undeformed. In the Western Cascade Group of Washington two general fold trends are recognized, one a north to northwest trend and the other an east to northeast trend. Bedding in the northwest trending folds dip $10^{\circ}$ to $45^{\circ}$ and the fold axes parallel the pre-existing Cenozoic trends. The east-west trending Yakima folds are the youngest (12 m. y.) and deform the Columbia River basalts. A broad northsouth trending synclinal trough underlies the range (Peck et al., 1964; Hammond, 1979).

Three general directions of faulting occur in the Cascade Range: northwest, east-west, and north-south. The nor thwest trending faults parallel the northwest-trending folds and are thought to have occurred with these folds. The east-west faults form a belt parallel to the Yakima folds but extend farther to the south into Oregon than do the folds. The north-southtrending faults are the youngest and appear to be normal faults developed under extensional stress producing a High Cascade graben in central Oregon (A1len, 1965; Taylor, 1981) and northsouth fissure zones along the length of the range. Taylor (1981) estimates that the faulting began $4.5 \mathrm{~m}$. y. ago. 


\section{CHAPTER III}

\section{ROCK UNITS}

Fifteen rock units were differentiated in the map area by the author (Figure 4). They range from surficial deposits to basaltic and andesitic lava flows to volcaniclastic sedimentary rocks and diorite intrusions. The units are described from oldest to youngest. The descriptions of each unit based on field and laboratory observation follows this order: 1) rock type, 2) location of the unit, 3) outcrop characteristics, 4) dimensions and volume, 5) petrographic composition and alteration, and 6) the relative age of the unit. Colors of the rocks are assigned by comparing hand samples with the Rock Color Chart (Goddard, et al., 1980). Present volumes of the volcanic units were estimated by reconstructing the paleotopography to determine thickness of the units and measuring the present area of the mapped unit with a digitizing planimeter. The stratigraphic ages were determined using radiometric dating and topographic expression. Mount St. Helens tephra was looked for but not found in the map area. In this report, the term mafic andesite denotes andesites containing 53 to 57 weight percent Si0 . Basalts contain less than 52 2 weight percent SiO and andesites contain 57 to 63 weight percent 2

Si0 . The appendices summarize the sample locations, and the petrographic and chemical data. 
AGE (Y.)

UNIT

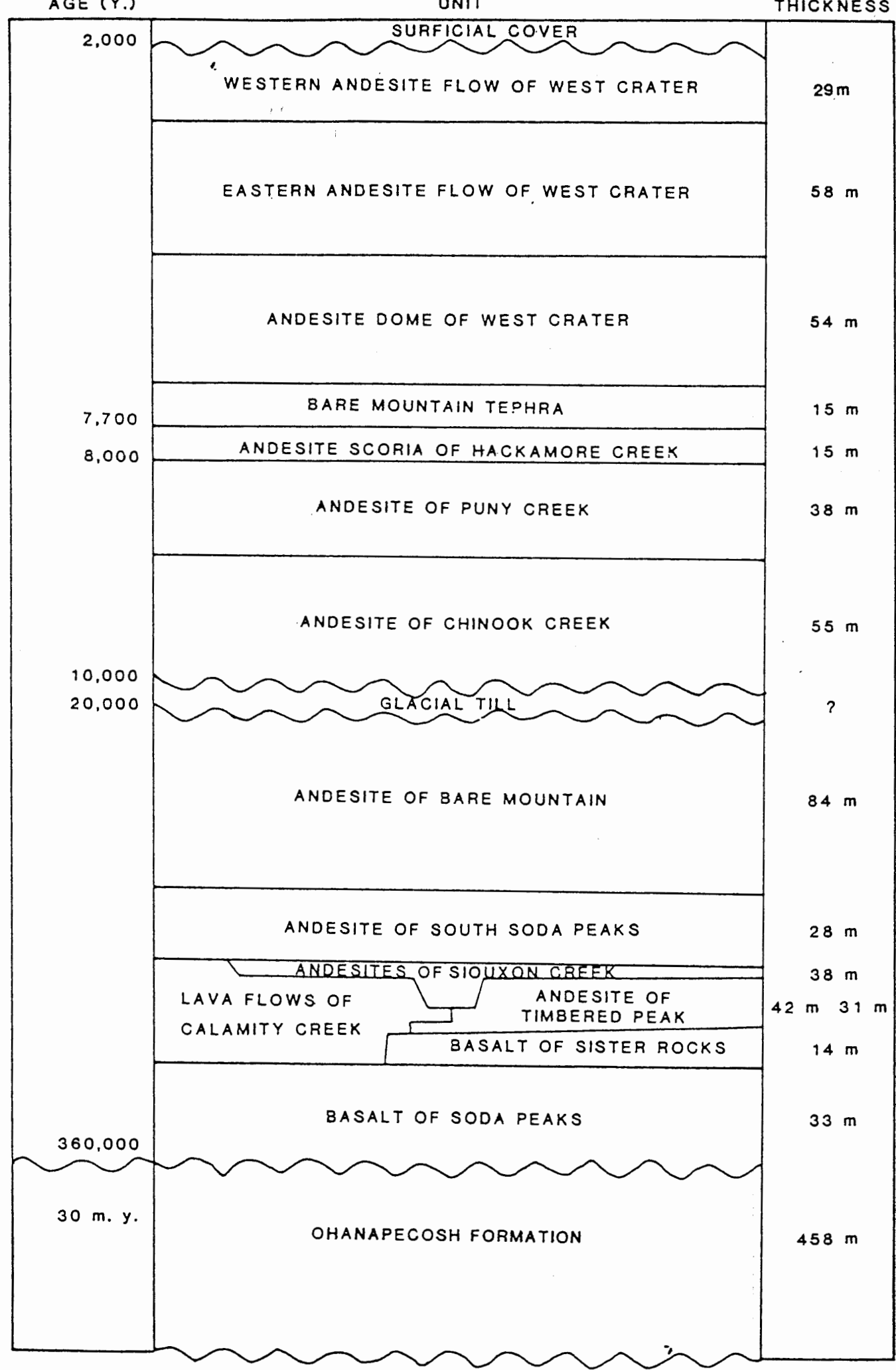

Figure 4. Composite stratigraphic column of map units in the West Crater-Soda Peaks Area. 
OHANAPECOSH FORMATION (To)

The Ohanapecosh Formation is the oldest map unit and underlies the entire study area (Figure 4). It is composed of interstratified laharic breccias, tuffs, volcaniclastic sedimentary rocks, and basaltic to andesitic lava flows. The most extensive exposures of the formation occur in the northeastern corners (Sec. 36, T.6 N., R.6 E.) and in the central portion of the map area Secs. 17, 20, 21, T.5 N., R.6 E.; Plate 1). Where not glaciated, outcrops are generally deeply weathered with a surface coating of clay. The lava flows are resistant to erosion and form ridges, terraces, and rims, while the generally underlying volcaniclastic sedimentary rocks form slopes. The formation has a maximum exposed thickness of $458 \mathrm{~m}$ and may be much thicker since the base of the formation is not exposed in the map area. In outcrop the breccias and volcaniclastic rocks range in color from light blue gree (5 BG $6 / 6$ ) to light olive gray ( 5 Y $5 / 2$ ); the interstratified lava flows are medium to dark gray ( 5 to $N 3$ ) to olive black ( $5 \mathrm{Y}$ $2 / 1)$. The clasts in the breccias vary in color from reddish brown (10 R) to blue green (5 BG) to black (N 1).

Petrographically, the laharic breccias and volcaniclastic sedimentary rocks contain 20 to 50 percent subangular to rounded clasts from several millimeters to a maximum of $25 \mathrm{~cm}$ in diameter. The clasts include basalt, andesite, pumice, and glass in a fine-grained matrix containing plagioclase, magnetite and 
pyroxene. The lava flows are phyric basalts to mafic andesites with 5 to 10 percent subhedral phenocrysts of plagioclase, 0.2 to $4.0 \mathrm{~mm}$, in a fine-grained felty to pilotaxitic groundmass (Appendix B). All rocks of the formation are pervasively altered to various stages of zeolite and pumpellyite facies of regional metamorphism. Alteration minerals include one or more of the following: clays, thought to be smectite, calcite, quartz actinolite, epidote, chlorite, crystobalite and several zeolites (Appendix B). Chemically, the flows range in composition from alkaline basalts to mafic andesites with silica contents of 52 to 55 weight percent (Appendix C). The age of the Ohanapecosh Formation in the Cascade Range of central Washington is about 36 to $28 \mathrm{~m}$. y. (Frizzell and Vance, 1983). The, Ohanapecosh strata in the map area are probably of about the same age range, although the strata have not been correlated with the type section to the north (Hammond, 1980).

\section{TERTIARY INTRUSIONS ( Ti )}

Many intrusions of probable Tertiary age cut the Ohanapecosh Formation. These intrusions are fine-grained basaltic to andesitic dikes, plugs, and sills. They are scattered throughout the map area. Some intrusions, such as Calamity Peak and Observation Peak, may represent subvolcanic magma chambers and feeder systems of eroded Tertiary volcanic centers. These two centers have numerous conjugate dike sets and 
small plugs. The largest dike complex occurs at Observation Peak where it forms three conjugate dikes. Elsewhere the dikes range from 1 to $10 \mathrm{~m}$ and average $3 \mathrm{~m}$ in thickness. Most dikes cannot be traced beyond the outcrop due to cover of forest and surficial deposits. The longest exposure of a dike is $0.75 \mathrm{~km}$. Most dikes trend northwest or northeast; a few strike north-south and eastwest.

A $120 \mathrm{~m}$-thick, $2.4 \mathrm{~km}$-1ong hornblende diorite sill occurs in the southwestern portion of the area (Sec. 29, T.5 N., R.6 E.). This sill is the largest single intrusion in the area; it 2 covers a total outcrop area of $1.35 \mathrm{~km}$. Intrusive plugs in the area are small and difficult to distinguish from the larger dikes. One plug in the southern portion of the map area (Sec. 32, T.5 N., R.6 E.) has warped the overlying Ohanapecosh beds into a small domelike structure.

Most intrusions are composed of gray, grayish green to brown fine-grained basalt and andesite. They contain anhedral to euhedral phenocrysts of plagioclase, augite or hypersthene, in a fine-grained diabasic to felty groundmass (Appendix B). Chemically the four intrusions analyzed range from 56 to 64 weight percent SiO (Appendix D).

HIGH CASCADE VOLCANIC ROCKS

The areas underlain by High Cascade volcanic rocks in the area are numerous and, except for the Bare Mountain, West Crater, 
and South Soda Peaks lava flows, occur chiefly as scattered andesitic to basaltic lava flows in single nonoverlapping flow units. Vents are recognized in many units by a thick deposit of scoria beneath the head of the flow. Where the vent has been eroded, as is common in the older flows, the vent area was interpreted from the distribution of the lava flow. The ages of the volcanic rocks range from 360,000 years, which is the $\mathrm{K}-\mathrm{Ar}$ age of the basalt of Soda Peaks, to probably no younger than about 2,000 years the estimated age of the West Crater flows (Figure 4). The stratigraphic order of the volcanic units was 14

estimated from $\mathrm{K}-\mathrm{Ar}$ and $\mathrm{C}$ radiometric dates (Table I), relative topographic expression, and the extent of glaciation (Table II). The volcanic rock units are informally named. Names applied to the units are derived from nearby topographic features or streams.

BASALT OF SODA PEAKS (Qsp)

Thick ( $>5 \mathrm{~km}$ ) lava flows of pyroxene basalts compose the Soda Peaks unit in the south-central part of the study area (Secs. $21,28,33,34$, T. 5 N., R.6 E.). In outcrop the basalts vary from platy to blocky jointed; locally they are vesicular. The color of the flows in outcrop is light gray (N 7) to medium light gray (N 6). The source or sources of the Soda Peaks flows has been removed by glaciation. The lava flows are covered by well-developed till, soil and forestion. Two flow units have 


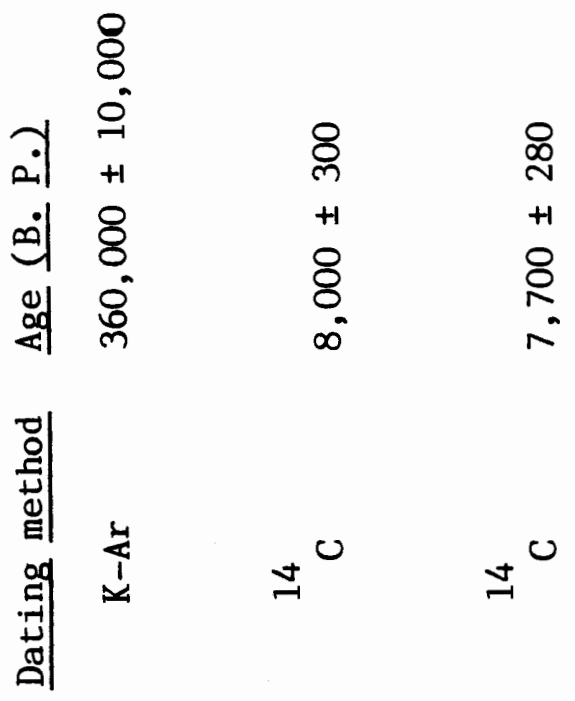

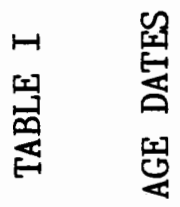
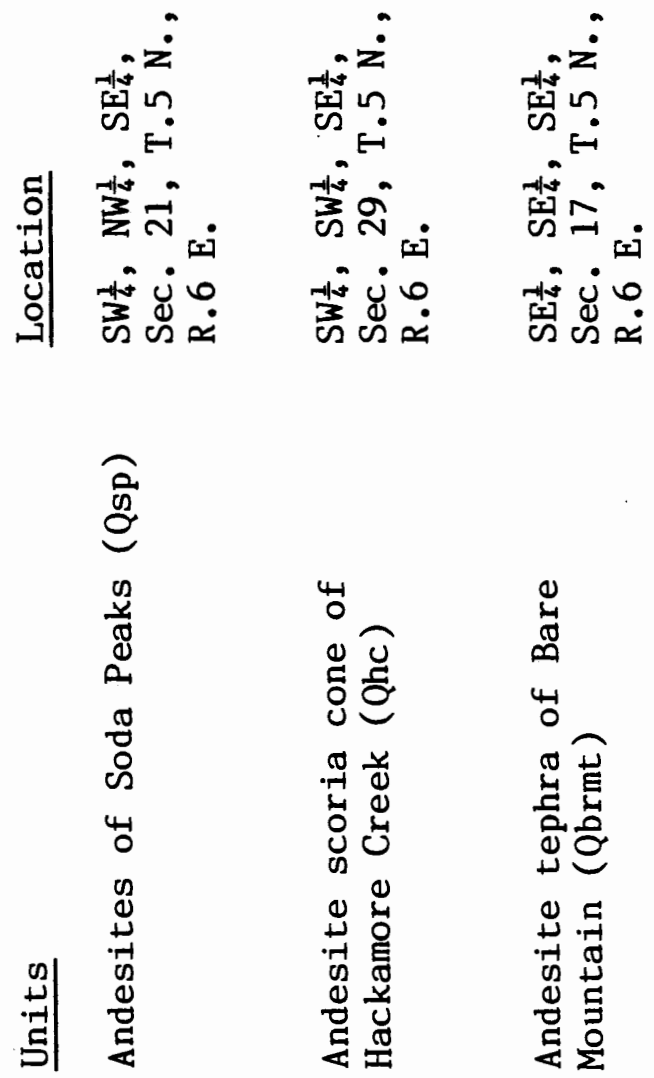
TABLE II

CRITERIA FOR STRATIGRAPHIC AGE DETERMINATION (YOUNGEST TO OLDEST)

Andesite of West Crater: based on freshness of the rubbly surface, and lack of dissection, mature forestation, soil cover; displacement of streams; overlies andesite of Hackamore Creek.

Andesitic tephra of Bare Mountain: overlies glacial till, ${ }^{14} \mathrm{C}$ age of $7,700 \pm 280$ years.

Andesitic scoria cone of Hackamore Creek: based on fresh rubbly lava flow and chute breaching the cone, the amount of loose scoria present, underlies West Crater andesite flow, overlies glacial till, $14 \mathrm{C}$ age of $8,000 \pm 300$ years.

Andesites of Puny Creek: lack of stream or glacial erosion, fresh look to the block lava flow and flow margins.

Andesite of Chinook Creek: lack of stream or glacial erosion, and lack of well-defined soil cover.

Glacial till of probable Fraser Glaciation

Andesites of Bare Mountain: moderately dissected, has smooth flow surfaces lacking primary features.

Andesite of South Soda Peaks: has an observable source with a scoria cone, flow is glacially dissected, underlies glacial till and colluvium.

Andesite of Timbered Peak: no recognizable source, flow truncated by glaciated valley.

Andesite of Siouxon Creek: flow is glaciated and extensively reforested.

Andesites of Calamity Creek: same as Siouxon Creek, may be of same age.

Basalt of Sister Rocks: a glaciated cirque cuts it on the north, heavily forested.

Basalt of Soda Peaks: lack of a recognizable source, heavily forested, appears to be glacially eroded, $\mathrm{K}-\mathrm{Ar}$ date of $360,000 \pm 10,000$ years. 
TABLE III

VOLUME OF HIGH CASCADE LAVA FLOWS (YOUNGEST TO OLDEST)

\begin{tabular}{|c|c|c|c|}
\hline FLOW NAME & THICKNESS (m) & $\begin{array}{l}\text { PRESENT } \\
\text { AREA } \\
(\mathrm{km}) \\
\end{array}$ & $\begin{array}{c}\text { PRESENT } \\
\text { VOLUME } \\
(\mathrm{km} 3) \\
\end{array}$ \\
\hline West Crater west flow end & 12.2 & 0.335 & 0.004 \\
\hline West Crater west flow & 29.2 & 1.352 & 0.039 \\
\hline West Crater east flow & 57.8 & 4.236 & 0.245 \\
\hline $\begin{array}{l}\text { West Crater dome } \\
*\end{array}$ & 54.2 & 0.471 & 0.025 \\
\hline * Bare Mountain tephra & 4.8 & 8.040 & 0.039 \\
\hline Hackamore Creek scoria & 15.3 & 0.196 & 0.003 \\
\hline Puny Creek andesite & 37.7 & 0.641 & 0.024 \\
\hline Chinook Creek andesite & 55.3 & 0.959 & 0.053 \\
\hline Bare Mountain andesites & 83.8 & 6.977 & 0.585 \\
\hline South Soda Peaks andesites & 28.0 & 1.380 & 0.039 \\
\hline Timbered Peaks andesite & 31.3 & 0.283 & 0.009 \\
\hline Siouxon Creek andesite east & 15.2 & 0.525 & 0.008 \\
\hline Siouxon Creek andesite west & 23.1 & 0.265 & 0.006 \\
\hline Calamity Creek andesite north & 20.3 & 0.552 & 0.011 \\
\hline Calamity Creek andesite south & 21.7 & 0.179 & 0.004 \\
\hline Sister Rocks basalt & 14.0 & 0.477 & 0.007 \\
\hline Soda Peaks basalt & 32.9 & 0.484 & 0.016 \\
\hline Soda Peaks basalt & 9.2 & 0.830 & 0.008 \\
\hline
\end{tabular}


estimated average thicknesses of 9.2 and $33 \mathrm{~m}$. Present volumes 3

are 0.008 and $0.016 \mathrm{~km}$ respectively (Table III). The lengths for the the lava flows is 0.9 to $1.25 \mathrm{~km}$.

Petrographically, the Soda Peaks lava flows are phyric olivine-pyroxene basalt. Subhedral, 0.1 to $0.7 \mathrm{~mm}$, phenocrysts of olivine and clinopyroxene occur in a fine-grained felty to diabasic groundmass of plagioclase, clinopyroxene and magnetite (Appendix B). A brown mica tentatively identified as a phlogopitic biotite occurs in the groundmass of the lava flows (Appendix B). This mica may be a secondary mineral as it fills the interstices in the groundmass. The basalt of Soda Peaks contains 50 to 52 weight percent SiO (Appendix C). These basaltic lava flows are the oldest unit of the High Cascade volcanic rocks in the map area. They are dated at $360,000 \pm 10,000$ years by the $\mathrm{K}-\mathrm{Ar}$ method (Figure 4, Table I).

\section{BASALT OF SISTER ROCKS (Qsr)}

A thick ( $>5 \mathrm{~m}$ ) flow of pyroxene basalt occurs in the east-central portion of the map area (Secs. 10, 11, T.5 N., R.6 E.) on the east side of Sister Rocks. The major outcrop of this flow is the steep slope $1 \mathrm{~km}$ southeast of the summit of Sister Rocks. The source of the flow is near a scoria deposit on the northeastern slope of Sister Rocks. The surface of the flow is thickly forested except for the steep talus slope along its eastern margin. The minimum estimated length of the flow is 1 
$\mathrm{km}$; the average thickness is $14 \mathrm{~m}$. With a lateral extent of 0.5 $\mathrm{km}$, the present volume of the unit is $0.007 \mathrm{~km}^{3}$ (Table III). The rock is medium dark gray (N 4) with a light gray (N 7) weathered surface, and consists of phyric olivine-pyroxene basalt. Subhedral plagioclase and olivine phenocrysts, up to 1 $\mathrm{mm}$ in size, occur in a fine-grained diabasic groundmass of plagioclase, augitic pyroxene and magnetite. This basalt flow contains tentatively identified secondary phlogopitic biotite (Appendix B). It contains 51 weight percent silica (Appendix C). Age relationships of this unit are uncertain. The basalt borders a glacial cirque, indicating that the flow is older than 10,000 years. The unit may of the same age as the andesite flows of Timbered Peak, Siouxon Creek, and Calamity Creek (>10,000 y., Figure 4).

A basaltic dike lies in contact with the north side of the basalt of Sister Rocks. The dike crops out as a 2 m-high ridge cutting the scoria deposit of the basalt flow. It is approximately 2 m-wide and is traceable for only $6 \mathrm{~m}$. Its outcrop color is medium dark gray ( $\mathrm{N}$ 4). The dike consists of microphyric augitic-olivine basalt with phenocryst up to $0.9 \mathrm{~mm}$ in length (Appendix B). The groundmass is fine-grained with a diabasic texture. It contains 52 weight percent silica (Appendix C). Because of chemical and petrographic similarity to the lava flow, this dike is considered part of the Sister Rocks units and is of the same age. 
ANDESITES OF CALAMITY CREEK (Qcal)

Thick lava flows occur west of Calamity Creek in two separate areas (Secs. 6, 7, T.5 N., R.6 E.). Because of its remoteness and inaccessability, the unit was not sampled and was mapped from visual observations at the creek bed and from aerial photographs.

The unit is truncated by a glaciated valley and is largely covered by forest except for a steep talus slope at the edge of the valley. The thickness of the lava flows was estimated to be $20 \mathrm{~m}$ for the northern flow and $22 \mathrm{~m}$ for the southern flow. The northern flow has a length of $0.9 \mathrm{~km}$ while the southern flow has a length of $0.5 \mathrm{~km}$. Calculated volumes of 3 the two parts are 0.011 and $0.004 \mathrm{~km}$ respectively (Table III). The color of the rocks in outcrop appears to be light gray (N 7) to medium gray ( $\mathrm{N}$ 6). The stratigraphic position of the unit is unknown. Its age is preglacial ( $>10,000$ years) as evidenced by the glaciated valley truncating the flows. This unit is probably of the same age as the basalt of Sister Rocks, and the andesites of Siouxon Creek and Timbered Peak (Figure 4).

\section{ANDESITES OF SIOUXON CREEK (QSC)}

The andesites of Siouxon Creek occur as two separate thick flows approximately $1.6 \mathrm{~km}$ apart, in the west-central portion of the map area, on the north side of Siouxon Creek (Secs. 4, 5, 9, T.5 N., R.6 E.). The flow rocks are glaciated and heavily 
forested. A steep talus slope extends from the lava flow rims to the creek bed, a vertical distance of about $240 \mathrm{~m}$. The source of the eastern flow was identified from the 3 to $5 \mathrm{~m}$ accumulation of scoria beneath the northern edge of the flow. Because of the distance separating the two flows, it is believed that the western flow came from a separate yet unidentified source. The flows are light gray (N 7), consist of porphyritic olivine andesite, and have an estimated thickness of $15 \mathrm{~m}$ for the eastern flow and $23 \mathrm{~m}$ for the western. The present volumes are 0.008 and $0.006 \mathrm{~km}$ respectively (Table III).

In thin-section, the rock is a porphyritic olivine mafic anesite. The phenocrysts, 0.3 to $2.0 \mathrm{~mm}$ in size, are euhedral to subhedral crystals of olivine in a fine-grained pilotaxitic and diktytaxitic groundmass of plagioclase, augite and magnetite. A secondary brown mica thought to be a phlogopitic biotite is found in the interstices (Appendix B). The andesites of Siouxon Creek are mafic andesites with a silica content of 55 weight percent (Appendix C). These flows are estimated to be preglacial in age and are probably correlative with the basalts of Sister Rocks and the andesites of Calamity Creek and Timbered Peak (Figure 4).

ANDESITE OF TIMBERED PEAK (QtP)

A thick andesite lava flow crops out in a quarry in the northeastern part of the map area, $1.7 \mathrm{~km}$ east of the summit of 
Timbered Peak (Sec. 35, T.6 N., R.6 E.). It is an intracanyon flow which has been breached by glaciation and now lines opposite sides of a valley. The same flow extends northward beyond the map area. No source vent was found. In outcrop the flow is massive with a smooth glaciated surface. The estimated thickness inside the map area is $31 \mathrm{~m}$ and the calculated present volume is 3

$0.009 \mathrm{~km}$ (Table III). The rock has a uniform medium gray (N 5) color.

The petrographic classification of one sample is a porphyritic augite-olivine mafic andesite. Subhedral to euhedral phenocrysts, 0.2 to $0.9 \mathrm{~mm}$ in diameter, of olivine with some plagioclase and augite occur in a fine-grained pilotaxitic groundmass of plagioclase and pyroxene (Appendix B). The silica content is 55 weight percent (Appendix $\mathrm{C}$ ). The exact age of the unit is not known but is considered to be preglacial $(>10,000$ years) because the flow is breached by a glaciated valley to the north (Table II). The andesite of Timbered Peak may be of the same age as the basalt of Sister Rocks and the andesites of Calamity Creek and Siouxon Creek (Figure 4).

\section{ANDESITES OF SOUTH SODA PEAKS (QsSP)}

Four moderately thick ( 1 to $5 \mathrm{~m}$ ) overlapping andesite flow units up to $2.4 \mathrm{~km}$ in length, are located in the south-central portion of the map area, $0.4 \mathrm{~km}$ south of the western summit of Soda Peaks (Sec. 34, T.5 N., R.6 E.). The flow surfaces are 
covered by 0.2 to $2.0 \mathrm{~m}$ of glacial till and colluvium. The unit has a well-preserved topographic expression and is only slightly dissected by drainage patterns. A source vent for these flows was determined from the exposure of a scoria cone beneath the flows on the southern slope of Soda Peaks. Outcrops show a pattern of platy jointing. The total average thickness of these overlapping flow units is $28 \mathrm{~m}$ with and estimated present 3 combined volume of $0.039 \mathrm{~km}$ (Table III).

This unit is a medium light gray (N 6) in color except for the basal portion of the youngest flow unit, which has a reddish brown color. This flow unit contains basaltic xenoliths, from underlying flow units, up to $6 \mathrm{~m}$ in length, and elongate bombs up to $46 \mathrm{~cm}$ in length. Petrographically these flows are a phyric olivine mafic andesite. The phenocrysts are subhedral to euhedral crystals of olivine up to $3.5 \mathrm{~mm}$ in size, altered to iddingsite along the fractures. They occur in a fine-grained pilotaxitic groundmass of plagioclase, augite, olivine and magnetite (Appendix B). The rocks have a silica content of 53 weight percent and are chemically mafic andesites (Appendix C).

The age of the andesites of South Soda Peaks is preglacial, because of the overlying till and colluvium. Lack of a paleosoil, which was stripped by glaciation, between the flow units and a cover of till and colluvium suggests that the age of the lava flows is close to the end of the glacial period $(10,000$ years). 
ANDESITES OF BARE MOUNTAIN (Qbrm)

Multiple thick flows of olivine basalt to mafic andesite are located in the central portion of the area (Secs. 5, 8, 9, $15,16,21$, T. 5 N., R.6 E.). In outcrop the flows generally have blocky jointing, locally some platy jointing, and vesicular basal portions. Soil covers the lava flows. Some of the flows are separated by layers of reddish brown scoria up to $45 \mathrm{~cm}$ thick. The estimated maximum thickness for the unit is $83 \mathrm{~m}$ (Table III) with the longest flow extending $5 \mathrm{~km}$ in length. The lava flows of Bare Mountain have the largest present volume in in the map 3 area $(0.585 \mathrm{~km} ;$ Table III). The source vent for the andesites of Bare Mountain has been identified to the south in the northern half of Sec. 21, T.5 N., R.6 E. This vent was possibly a cinder cone which was destroyed in later explosive eruptions.

Fresh flows range in color from a light gray (N 7) to a medium gray (N 5) and weather to a light brownish gray (5 YR 6/1). Petrographically, this unit ranges from phyric olivine basalts to mafic andesites with 0.1 to $2.0 \mathrm{~mm}$ phenocrysts of subhedral to euhedral olivine and pyroxene in a fine-grained pilotaxitic diabasic to felty groundmass of plagioclase, clinopyroxene and magnetite. Groundmass olivine is found in some of the flows (Appendix B). Chemically, the lavas of Bare Mountain contain 52.5 weight percent SiO (Appendix C). The age of the flows has been estimated to be interglacial, between 20,000 and 10,000 years ago, since the flows fill a valley, which 
was subsequently glaciated, and rim the edge of a youthful glacial cirque of the northeast slope of Bare Mountain. The flow surfaces are smooth and lack primary flow structures.

\section{ANDESITE OF CHINOOK CREEK (QCC)}

A thick intracanyon lava flow of olivine andesite lies in the northern part of the map area south of Chinook Creek (Secs. 20, 28, 29, T.6 N., R.6 E.). It has a smooth top with little soil development and a lack of glacial features. The flow is a block lava flow with fresh outcrops that have a blocky jointing pattern. The source vent has not been located. Chinook Creek, which flows to the north and west of the andesite, appears to have been displaced around the flow. The flow has a thickness of $55 \mathrm{~m}$ and is $2.5 \mathrm{~km}$ long. The present volume of this andesite is 3

estimated to be $0.053 \mathrm{~km}$ (Table III). Outcrops of this unit show a medium light gray ( $N$ 6) color.

The lava flow of Chinook Creek is fine-grained with microphenocrysts 0.3 to $0.6 \mathrm{~mm}$ in size. The phenocrysts are subhedral to euhedral crystals of olivine and plagioclase in a fine-grained slightly diktytaxitic felty groundmass of plagioclase and augitic pyroxene. The groundmass also contains a secondary brown mica thought to be a phlogopitic biotite (Appendix B). The flow has a composition of a mafic andesite; it consists of 54 weight percent SiO (Appendix C). The age is 2 postglacial ( $<10,000$ years) as determined from the lack of 
glacial features and the well- defined topographic expression (Table II).

ANDESITES OF PUNY CREEK (QPC, QuPC)

A short thick intracanyon flow is located in the westcentral portion of the map area north of Puny Creek (Sec. 17, T.5 N., R. 6 E.). To the north of the intracanyon flow lies another medium light gray (N 6) outcrop of similar rock. This flow has been called the upper Puny Creek flow (Qupc) and may be related to the Puny Creek andesite to the south although the source vent for the upper flow was not located.

The lava has a smooth flow-top and steep talus covered side and is undissected. It flowed south for $1.4 \mathrm{~km}$ into the glaciated valley of Puny Creek and covers an area of $0.64 \mathrm{~km}$ (Table III). The lava flow has a platy jointing pattern parallel to the slope of the valley wall. Near the source vent this parallel jointing becomes random and disoriented. The source for the flow is presumed to be atop the ridge where the jointing is disheveled. The average thickness of the Puny Creek andesite is 3 $38 \mathrm{~m}$ and the present volume of the flow is $0.024 \mathrm{~km}$ (Table III). the thickness of the upper Puny Creek subunit is undeterminable therefore no volume was calculated for the flow.

In outcrop the lava has a light brownish gray (5 YR 6/1) base grading up to a medium light gray (N 6) to light gray (N 7) interior and top. The lava flows of Puny Creek and upper Puny 
Creek are classified as phyric pyroxene-olivine mafic andesites. Phenocrysts of euhedral to anhedral olivine and pyroxene, up to $2.0 \mathrm{~mm}$ in size, make up 5 percent of the rock. They occur in a fine-grained pilotaxitic groundmass of plagioclase with intergranular pyroxene and magnetite (Appendix B). Both subunits of the Puny Creek andesite contain 54 weight percent SiO (Appendix C). Lack of evidence of glaciation indicates an age of less than 10,000 years although the exact age is unknown (Table II).

ANDESITIC SCORIA CONE OF HACKAMORE CREER (Qhc)

The andesitic scoria cone of Hackamore Creek is located on the north side of the glaciated valley of Hackamore Creek in the southwest part of the map area (Sec. 29, T.5 N., R.6 E.). The cone has steeply dipping flanks and has a rubbly chute extending down the south flank of the cone to the base of the valley where it is overlapped by the western andesite flow lobe of West Crater. A small amount of scoriaceous andesite lava occurs in this chute. Fresh and unweathered coarse pebble-sized and loosely consolidated scoria blankets an area within $200 \mathrm{~m}$ of the cone. The height of the cone estimated to be at least $15 \mathrm{~m}$. Because of the steep terrain and erosion, accurate thickness measurements of the scoria were difficult to obtain. The scoria blanket appears to thin rapidly to a thickness of $0.5 \mathrm{~m}$ at $200 \mathrm{~m}$ away from the cone. The original volume is estimated to be 0.003 
3

$\mathrm{km}$ (Table III). The color of the ejecta ranges from moderate reddish brown $(10 \mathrm{R} 4 / 6)$ in the highly oxidized core of the cone to brownish black (5 YR 2/1) near the margins of the deposit.

The andesitic scoria contains 0.1 to $1.2 \mathrm{~mm}$ anhedral to euhedral phenocrysts of plagioclase, pyroxene, and some olivine in a glassy groundmass with a few plagioclase and pyroxene microlites (Appendix B). Chemically, the scoria of Hackamore Creek is an andesite containing 58 weight percent SiO (Appendix C). The cone is the third youngest volcanic feature in the area with a ${ }^{14} \mathrm{C}$ age of $8,000 \pm 300$ years (Figure 4; Table I). The carbon for the age date came from carbonized twigs beneath the scoria (Table I).

\section{BARE MOUNTAIN TEPHRA DEPOSITS (Qbrmt)}

Sometime after the eruption of the andesitic lava flows of Bare Mountain, andesitic tephra was explosively erupted at Bare Mountain forming a maar-1ike crater $60 \mathrm{~m}$ deep and $300 \mathrm{~m}$ wide at the rim. Andesite tephra from the eruption or series of eruptions blanketed the area to a minimum depth of $10 \mathrm{~m}$. Major exposures of the tephra occur chiefly to the south within 0.6 to $1.8 \mathrm{~km}$ of the crater although they may be found farther to the north on top of the Bare Mountain lava flows. The tephra is generally unconsolidated and varies from boulder to gravel sized. A few consolidated outcrops of the tephra can be found near the base of the deposit. Thickness measurements of the tephra at 
four outcrops showed a general dispersal pattern to the north. Although much of the tephra has been eroded, its original volume is estimated at $0.039 \mathrm{~km}^{3}$ (Table III).

The tephra is colored light olive gray ( 5 Y 6/1) to brownish gray (5 YR 4/1). It contains both juvenile and accidental material. Juvenile clasts of the tephra are a gray scoriaceous hornblende mafic andesite, containing subhedral to euhedral phenocrysts of plagioclase, clinopyroxene and magnetite (Appendix B). The accidental material is composed of older Bare Mountain lavas, which may have been torn from the conduit of the vent, and of broken pieces of the Ohanapecosh Formation in which the crater was formed.

The formation of the crater and resulting tephra is dated 14 at or younger than $7,700 \pm 280$ years by the $C$ method (Table I). The carbon sample for the age date was taken from woody fragments beneath $2.0 \mathrm{~m}$ of coarse tephra, overlying weathered glacial till, $0.8 \mathrm{~km}$ west of the crater (Sec. 17, T.5 N., R.6 E.; P1ate 1; Table I). The eruption of the Bare Mountain tephra may have occurred close to the time that the scoria cone of Hackamore Creek was forming as part of an overall activity period in the map area.

ANDESITES OF WEST CRATER (QWC)

The andesites of West Crater occur in the southernmost portion of the map area (Secs. 20, 32, 33, 34, T.5 N., R.6 E.). 
The unit consists of three subunits, two tongues of thick lava flows and a dome. The flows moved out along glaciated valleys in opposite directions after the emplacement of the dome. Masses of vesicular domal rock occur atop the north levee of the west lava lobe. This evidence together with the abrupt steepness of the west side of the dome supports the hypothesis that the dome was emplaced before the outpouring of the lava tongues. With the exception of some pinacles, which may have been spines, the surface of the dome is uniformly rounded, split locally by cooling cracks. No evidence was found of separate or stacked lobes in the dome; so the dome is interpreted to be endogenous. A smal1 6 m-deep depression occurs in the top of the dome. It may have originated by collapse of the dome surface following removal of lava during formation of the flow lobes.

The western flow lobe has a low relief surface with $3 \mathrm{~m}-$ high pressure ridges perpendicular to the direction of flow. Two 15 m-high levees occur at the margins of the flow and extend 0.5 km downstream. These features are characteristic of a "fluid" block lava flow. The eastern flow lobe contains a minimum of ten flow subunits and is characterized by a rough blocky surface, indicative of a "viscous" block lava flow. Both flow lobes have steep undissected margins and pond streams at their snouts. Soil development atop the flows is slight especially on the blocky eastern 1obe. 
The $4.7 \mathrm{~km}-1$ ong western flow lobe has an average thickness 3

of $26 \mathrm{~m}$ and a volume of $0.043 \mathrm{~km}$ (Table III). The $3.0 \mathrm{~km}-1$ ong 3 eastern lobe has a volume of $0.245 \mathrm{~km}$ and a thickness of $58 \mathrm{~m}$ (Table III). The dome which appears to have been emplaced on a ridge that separates two glaciated valleys has an estimated height of $54 \mathrm{~m}$ and a volume of $0.025 \mathrm{~km}$ (Table III).

Except for numerous oxidized and leached zones, the domal rock is light gray (N 7 ) with a weathered color of dark yellowish brown (10 YR 4/2). The oxidized zones are mainly composed of clays and represent alteration by fumaroles during cooling and degassing of the dome. The lava flows are medium light gray (N 6) to a medium gray ( $\mathrm{N} 5$ ). The, southern levee of the western flow lobe has a grayish red $(10 \mathrm{R} 4 / 2)$ oxidized basal zone grading to a medium gray ( $\mathrm{N}$ ) interior.

Rocks of the two flow lobes are similar. They consist of phyric pyroxene andesites and contain anhedral to euhedral phenocrysts, up to $1 \mathrm{~mm}$ in size, of plagioclase, orthopyroxene, and clinopyroxene in a fine-grained felty to cryptocrystalline groundmass. The dome consists of pyroxene hornblende andesite with phenocrysts, 0.4 to $0.7 \mathrm{~mm}$ in size, of subhedral plagioclase, hornblende, and augite in a fine-grained pilotaxitic groundmass of plagioclase, hornblende, pyroxene and magnetite (Appendix B).

The andesites of West Crater are the youngest of the High Cascade volcanic units. An age of less than 7,700 years to 
possibly as young as 2,000 years is estimated for the unit because of the fresh rubbly surface on the eastern flow lobe and the lack of a well-defined soil cover on both flow lobes and the dome. The well-preserved topographic expression is also indicative of a young age (Table II).

$$
\text { SURFICIAL DEPOSITS (Qgt, QCol, Qal) }
$$

Surficial deposits in the map area consist of glacial till, colluvium and scoriaceous tephra. The till and colluvium occur on the surface primarily in the southeastern portion of the map area, although the entire area has been glaciated, while the tephra is concentrated around Bare Mountain and the Hackamore Creek scoria cone.

The till is compacted and poorly sorted. It has an exposed thickness to $20 \mathrm{~m}$ near Soda Peaks and may be thicker in the less rugged area to the south. The color of the till is dark brown, and is weathered at the surface to a yellowish brown. It is composed of unsorted rounded clasts up to boulder size in a silt matrix. The clasts consist of rocks of the Ohanapecosh Formation and some of the older High Cascade lava flows. The age of the till is estimated to be of Fraser age between 20,000 and 10,000 years (Crandell and Miller, 1974).

The entire map area appears to have been glaciated at least once as evidenced from the extent of the till. One or possibly several minor glaciations not covering the entire area appears to 
have occurred. The evidence for the minor glaciations is the presence of cirrques cutting into lava flows that fill glaciated valleys. The minor glaciation or glaciations were generally centered at or above an elevation of 3,000 feet on the north sides of ridges were the glaciers created numerous cirques. The cirques appear to have been created only where the center of glaciation was in contact with an intrusion or lava flow.

The colluvium occurs chiefly on the south slope of Soda Peaks. It is poorly sorted and unconsolidated. Its thickness is estimated at 1 to $2 \mathrm{~m}$. The colluvium is deeply weathered with a moderate yellowish brown color. Most material comprising the colluvium is a weathered phyric plagioclase basalt possibly from Soda Peaks. The clasts are cobble to boulder sized and are subangular to angular. The age of the colluvium is estimated to be younger than 10,000 years because it overlies the glacial till.

The creek beds are generally covered with unconsolidated silt to boulder size alluvium composed of the various rock types in the creek drainage systems. 


\section{STRUCTURE}

Broad shallow folds and northwest to northeast trending intrusions characterize the structure of the map area. The strata are deformed into a series of anticlines and synclines plunging to the northwest (Plate 1). The folding has a regional dip to the southwest of no more than $35^{\circ}$. The steepest dips of 0 35 occur in the northeastern portion of the map area. The central part of the area appears to be the broad crest of an anticline whose flanks dip generally less than $15^{\circ}$.

No large scale faulting was observed in the area. Many shear planes were observed in the bedding of the Ohanapecosh Formation. These shear planes show little or no displacements and random orientations. The shear planes are characterized by 15 to $30 \mathrm{~cm}$-wide zone of weathered gouge.

Dikes and intrusions in the map area strike chiefly in northwest and northeast directions. The dikes commonly occur in conjugate sets. Some of the dikes and intrusions locally warp the bedding in the Ohanapecosh Formation.

The age or ages of the folding and faulting is difficult to determine because of the lack of Upper Tertiary units in the area. The age is known to be Tertiary as the younger Quaternary units are undeformed. 
The general northwestward and northeastward structural trends of the folding and intrusions parallel the regional trends of the Cascade Range. The trends may have formed in a system where there was a north-south compressional stress and an eastwest extensional stress (Hammond, 1980).

The map area lies along the southward projection of a possible northwest-trending tectonic zone delineated by seismic activity associated with the eruptions of Mount St. Helens (Weaver, 1981). Although no faulting was observed in the area, the proximity of the numerous eruptive centers to the tectonic zone and their density, 13 centers within $100 \mathrm{~km}$, define a zone of undetermined significance and may indicate some type of subjacent crustal weakness. 


\section{CHAPTER V}

\section{GEOCHEMISTRY}

High Cascade volcanic rocks in the map area have silica contents of 50 to 58 weight percent, and are high-alumina ( $>16$ weight percent $A 10)$, and are classified as calc-alkaline 23 basalt and andesite (Figures 5 and 6; Appendix B). According to the classification of basalts, the High Cascade rocks are magmas of destructive plate margins (Wood et al., 1979; Figure 7). Most of the volcanic units are medium-K mafic andesites, while two units, West Crater and Hackamore Creek, are classified as medium to low-K andesites (Gill,1980; Figure $8 \mathrm{~A}$ ). Basalts ( $<53$ weight percent Si0) characterize the two oldest volcanic rock units, Soda Peaks and Sister Rocks.

On the basis of major, minor and trace-element chemistry, the rock units are divided into four chemical groups (Figures 8 to 11). They are: 1) the Sister Rocks chemical group, 2) the Soda Peaks chemical group, 3) the Bare Mountain chemical group, and 4) the West Crater chemical group.

The Sister Rocks group is the most primitive on the basis of $\mathrm{FeO}$ and $\mathrm{MgO}$, containing basalts of high $\mathrm{MgO}$ contents and low iron enrichment (Figures $8 \mathrm{C}$ and 9). The group has intermediate contents of $\mathrm{K} \mathrm{O}$ and $\mathrm{PO}$ compared to the other three groups. $2 \quad 25$

Trace-element content, especially the light rare earth elements (LREE), is moderately enriched (Figures 10 and 12). 


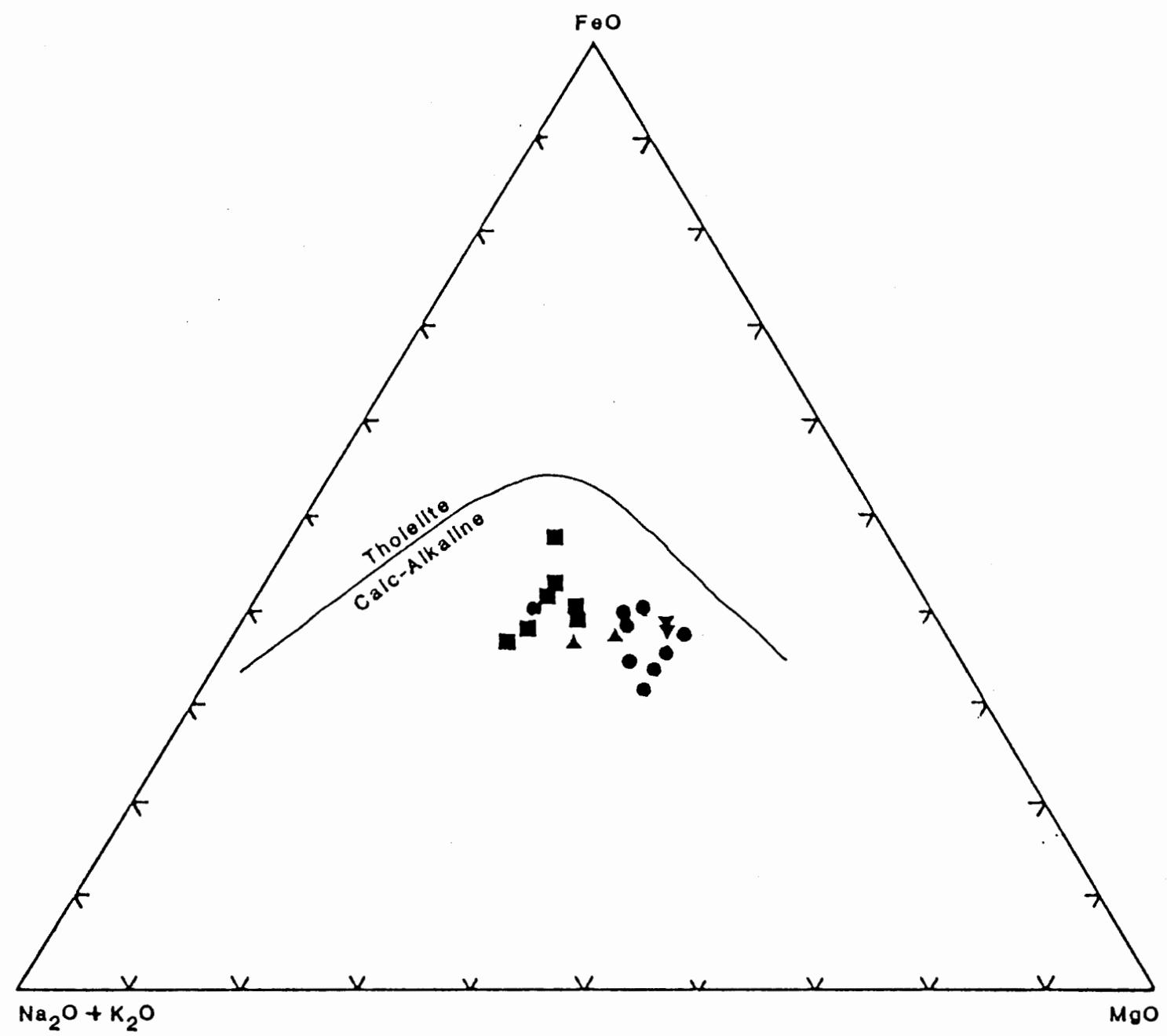

Figure 5. AFM diagram showing the calc-alkaline nature of the rock units (after Irvine and Baragar, 1971). Key to symbols: $\Delta$ Soda Peaks chemical group, $\boldsymbol{\nabla}$ Sister Rocks chemical group, Bare Mountain chemical group, West Crater chemical group. 


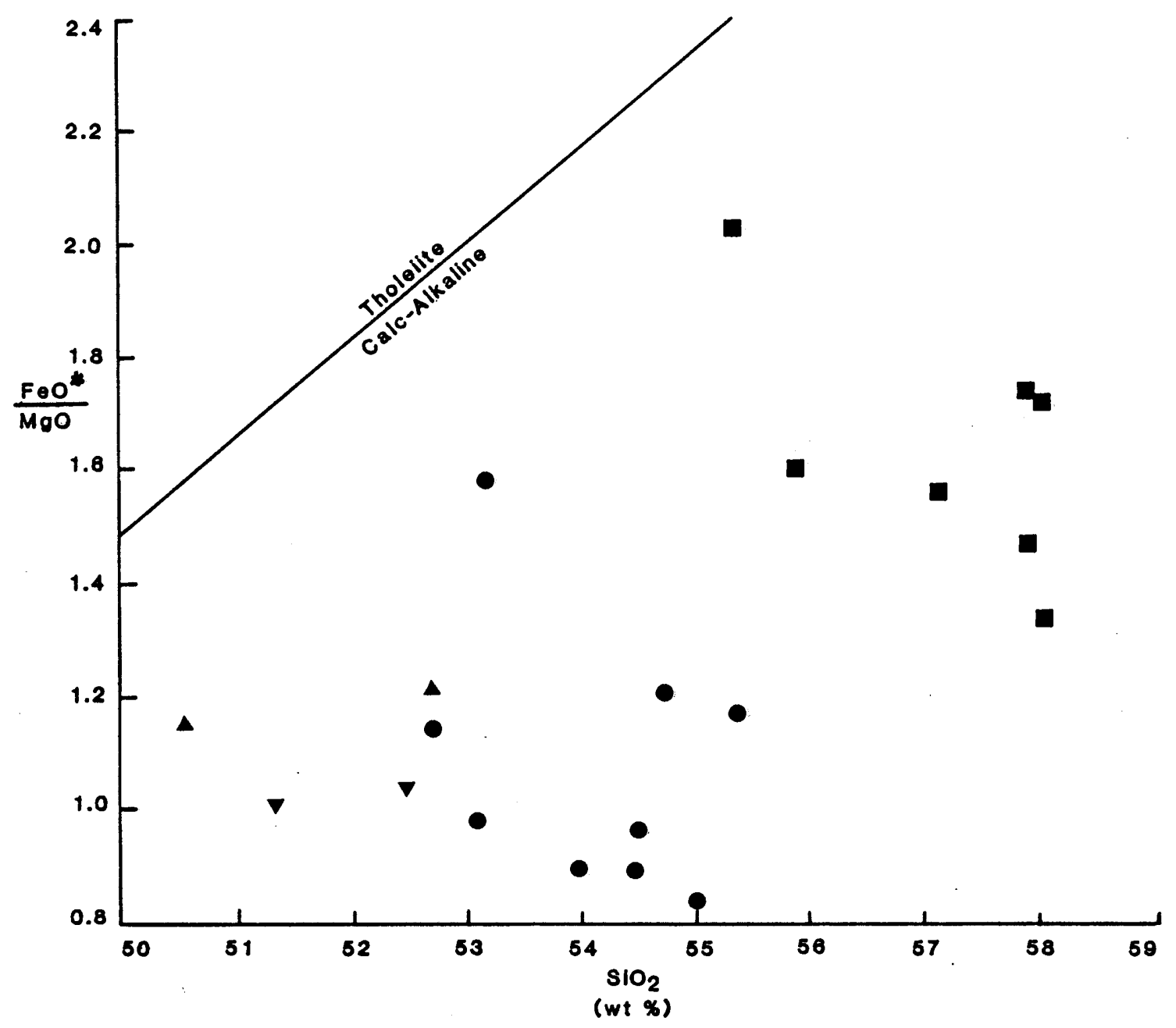

Figure 6. $\mathrm{FeO} / \mathrm{MgO}$ vs Si02 variation diagram showing tholeiitic and calc-alkaline fields. Symbols as in Figure 5. 


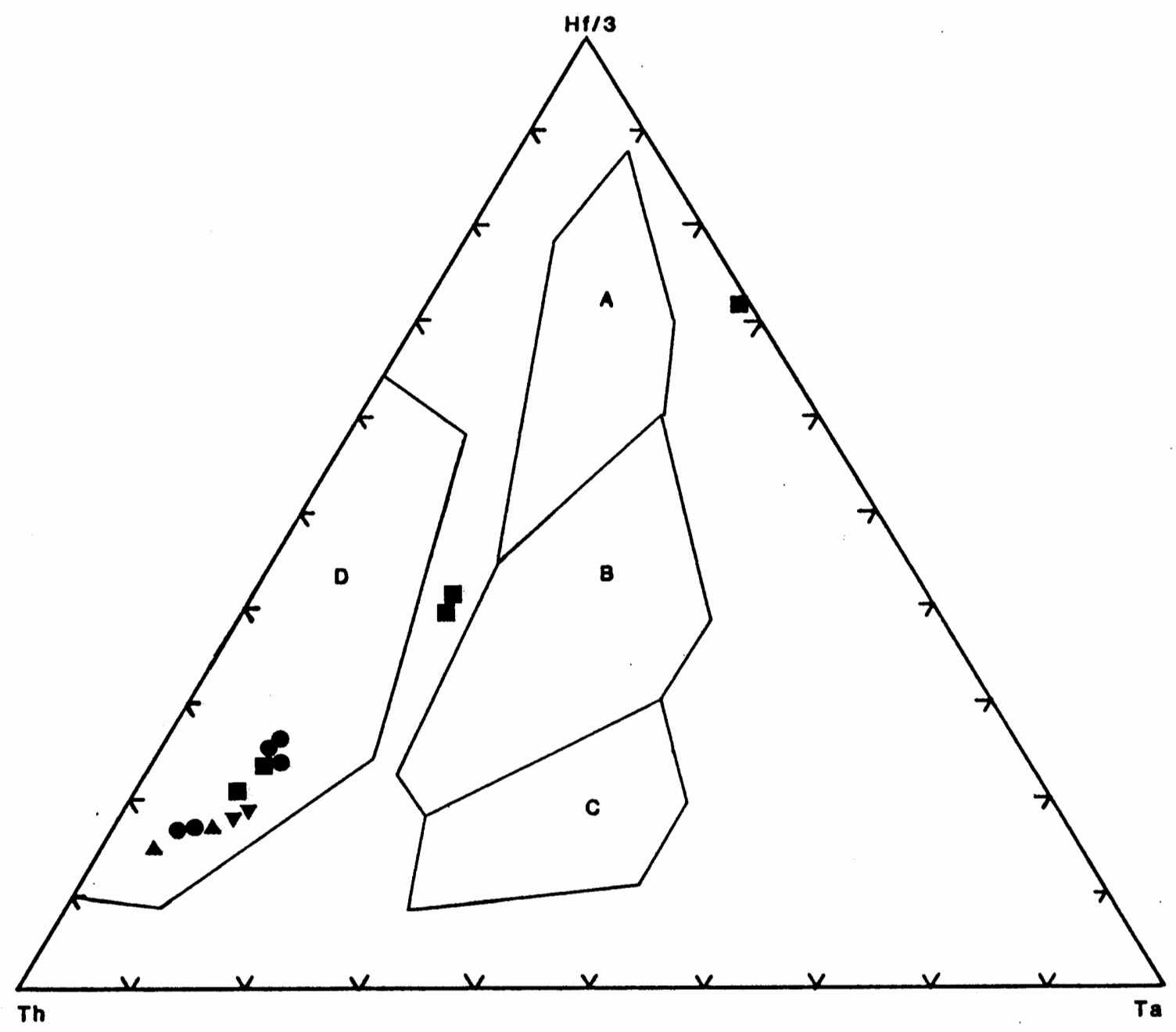

Figure 7. Th-Ta-Hf diagram tectonically classifying basalts (after Wood et al., 1979). Symbols represent samples from the study area as in Figure 5. Key to fields: A, normal MORB; B, anomalous MORB, ie., Iceland; C, plate basalts; $D$, destructive plate basalts; The samples between fields $B$ and $D$ are andesites and do not fall into the classification scheme. 
A

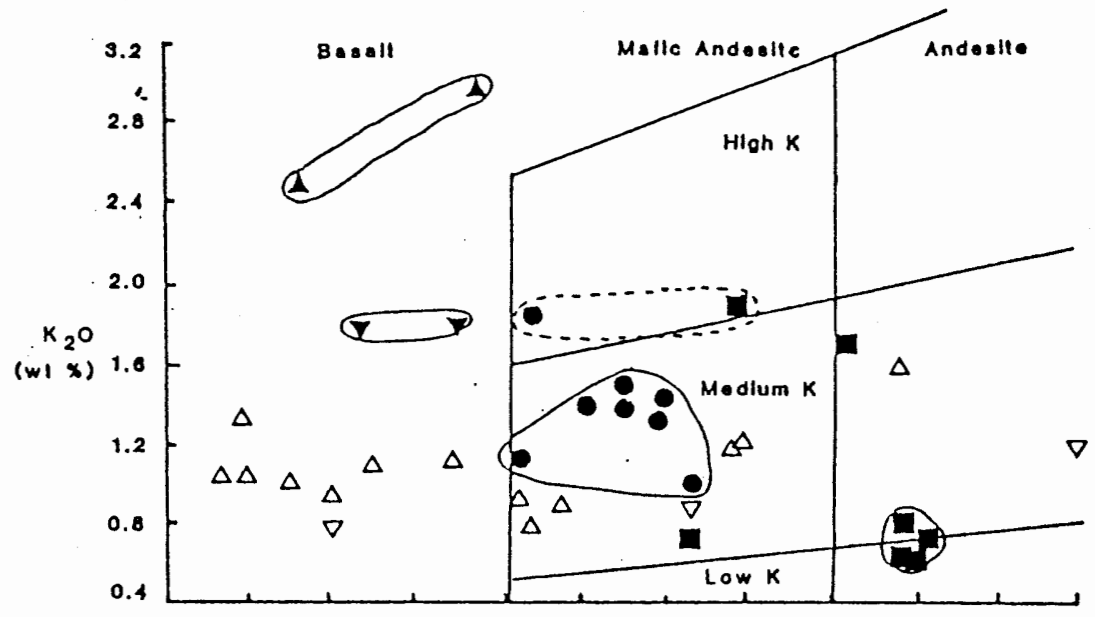

$\mathbf{B}$

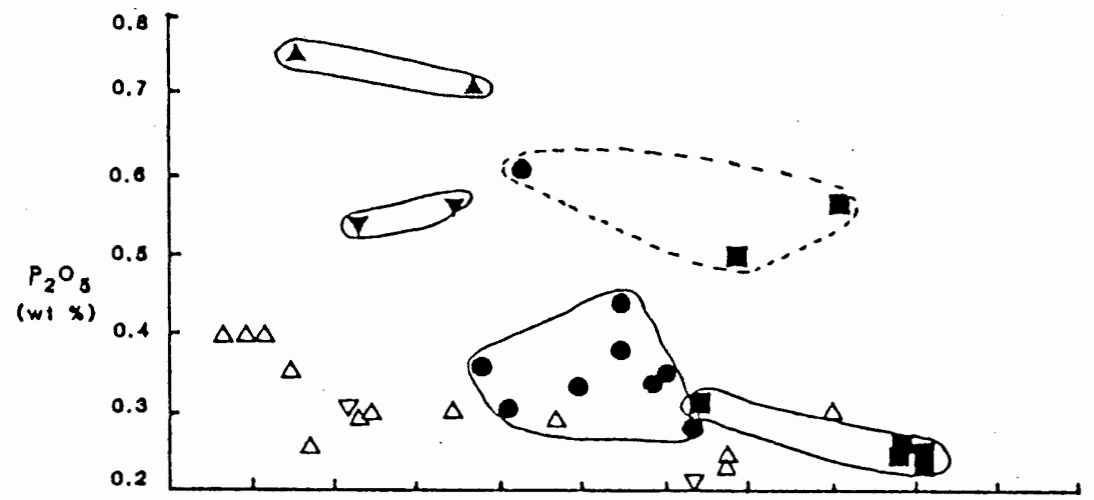

C

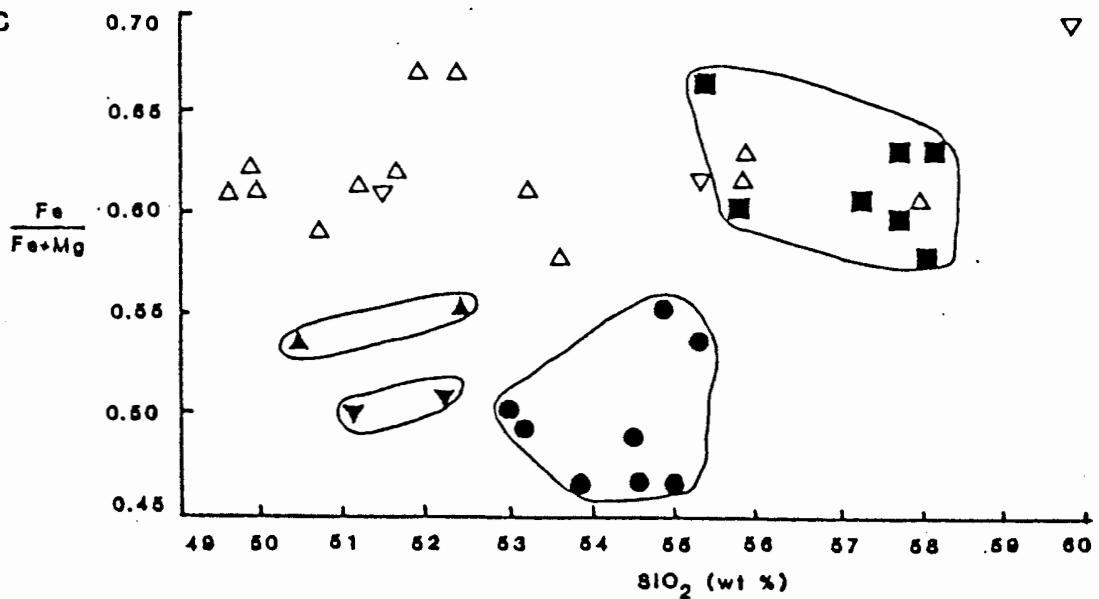

Figure 8. Si02 variation diagrams showing the four chemical groups in the major elements (solid lines). The dashed lines enclose the subgroup of the most differentiated rocks of West Crater and Bare Mountain. Key to symbols as in Figure 5 and: $\Delta$ basalts of Mount Hood (Wise, 1969); and $\square$ Average Oregon andesite (White and McBirney, 1979). 

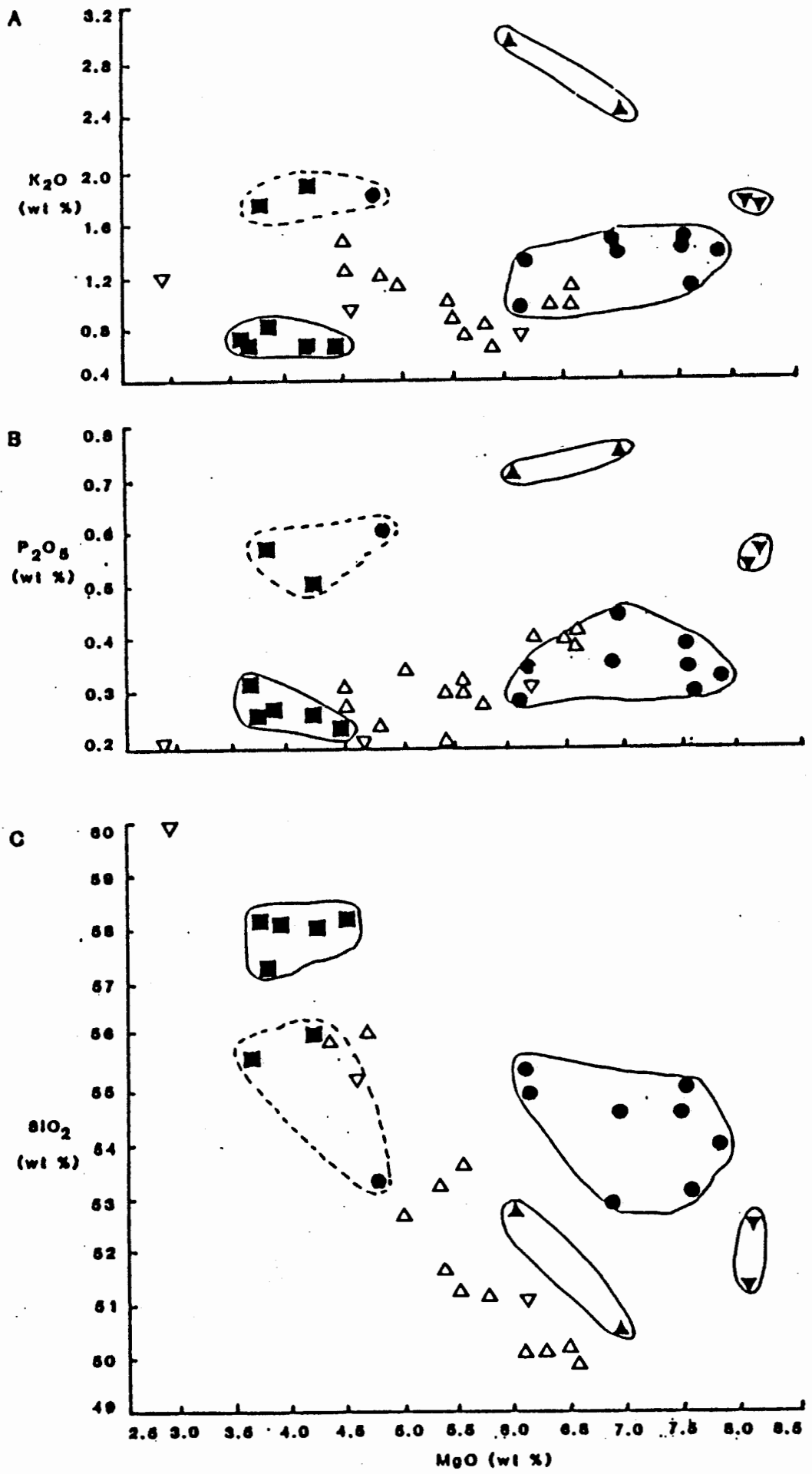

Figure 9. Mg0 variation diagrams showing the four chemical groups in major elements and comparing the samples to Oregon Hig Cascade rocks. Symbols as in Figures 5 and 8 . 

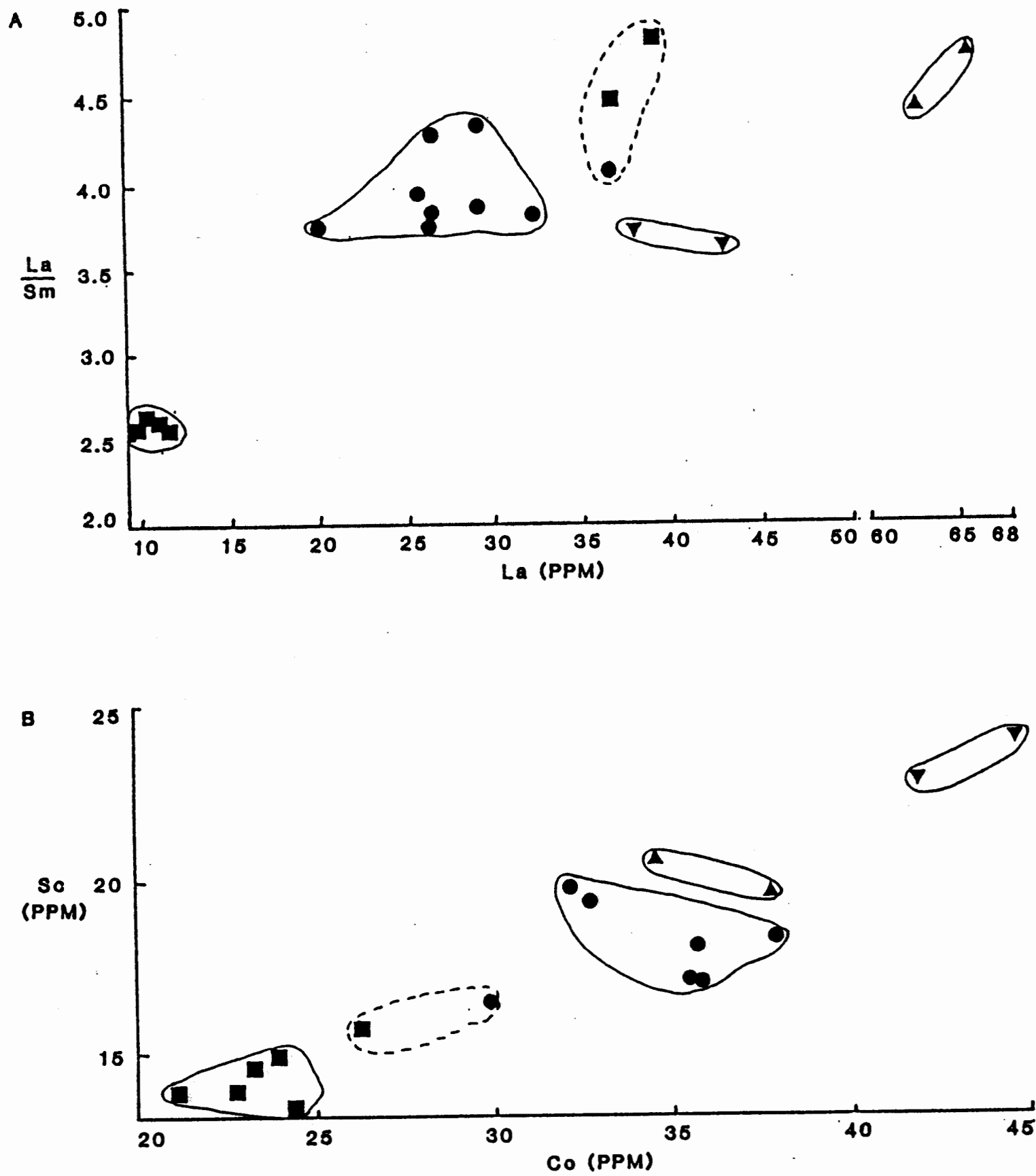

Figure 10. Trace element variation diagrams showing: A) LREE enrichment and B) the four chemical groups in the minor elements. The dashed lines enclose the subgroup of the most differentiated rocks of the West Crater and Bare Mountain units. Symbols as in Figure 5. 

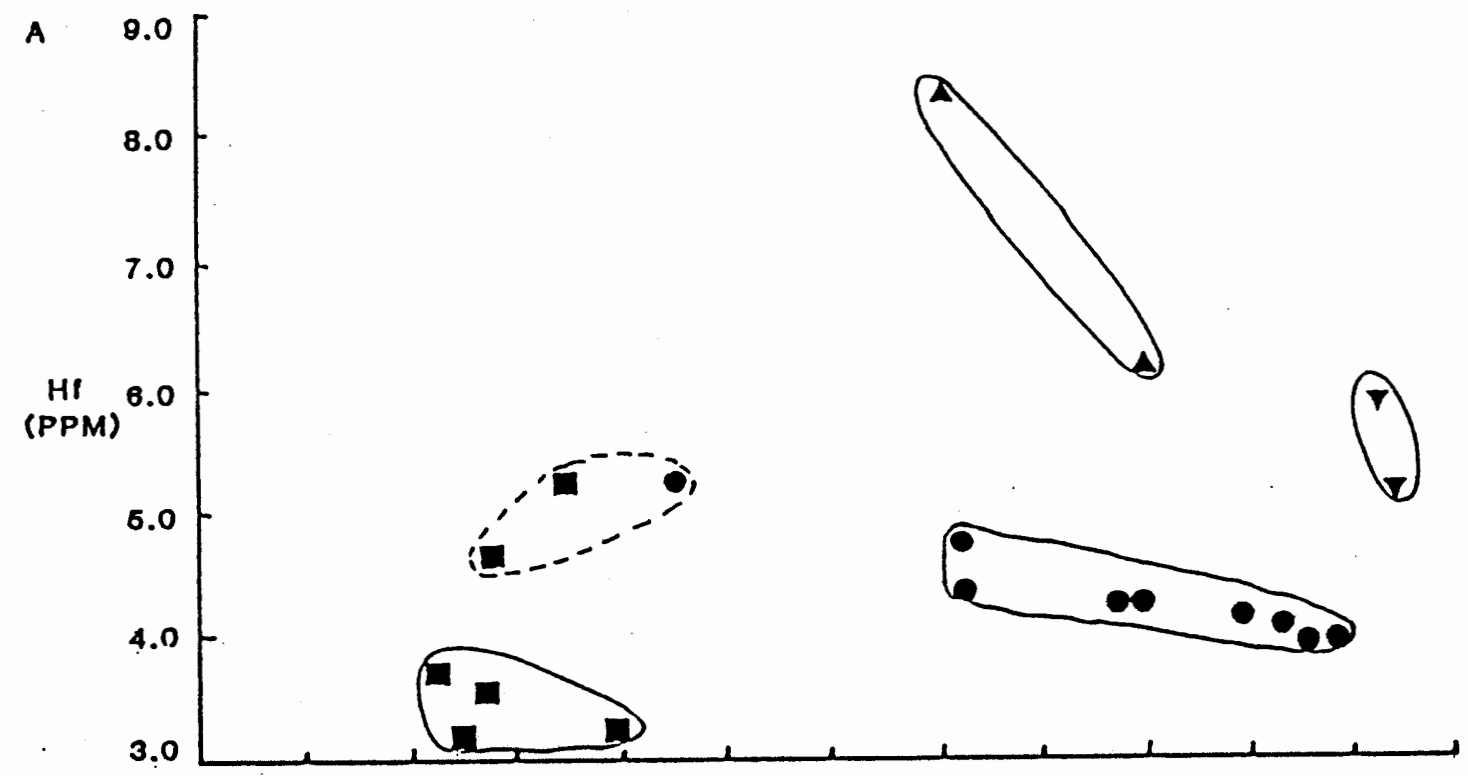

B

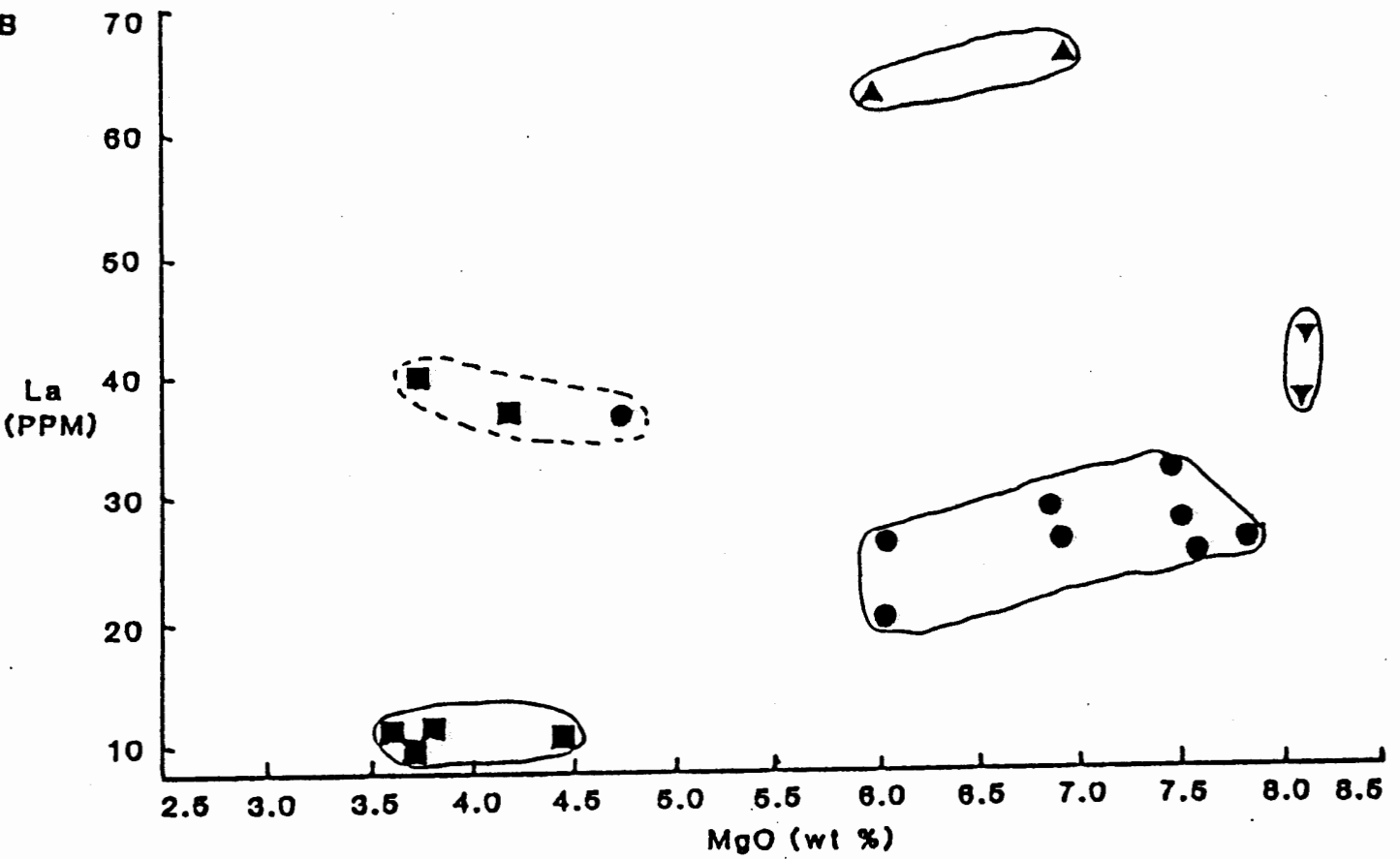

Figure 11 Hf and La vs MgO variation diagrams showing the four chemical groups in the trace elements. A) in a HREE, B) in a LREE. Symbols as in Figure 5. 
The Soda Peaks chemical group has silica values that overlap those of the Sister Rocks group and is considered to be the second most mafic chemical group (Figure $8 \mathrm{C}$ ). This group contains the oldest rock unit in the map area, the basalt of Soda Peaks. Characteristic of the group are high $\mathrm{K} O$ and $\mathrm{P} O$ Soda Peaks. 2025 contents and a high enrichment in LREE (Figures 8,9,10,12).

The third chemical group is the Bare Mountain group. It contains the majority of the rock units in the map area and has the largest chemical variation. The rocks of this group are more differentiated than the preceeding two groups (Figure $8 \mathrm{C}$ ) and can be classified as medium-K mafic andesites (Gil1, 1980; Figure $8 \mathrm{~A}$ ). The $\mathrm{P} O$ and $\mathrm{REE}$ abundances are moderately low (Figures 8 to 11$)$. 25

The final and most differentiated chemical group with respect to $\mathrm{FeO}$ and $\mathrm{MgO}$ is the West Crater chemical group (Figure $8 \mathrm{C})$. It contains the youngest volcanic rock units in the map area as well as those units with the highest silica values. The rocks are classified as medium to low-K andesites (Gill, 1980; Figure $8 \mathrm{~A}$ ). The group has the lowest $\mathrm{MgO}$ content and the highest iron enrichment of the four groups. $P O$ and REE abundances are generally low. 25

The most highly differentiated products of the West Crater and Bare Mountain volcanic units comprise a possible chemical subgroup outside the four major groups. The subgroup is characterized by medium to high silica and $\mathrm{K} 0$, intermediate $\mathrm{P} \mathrm{O}$, and low $\mathrm{MgO}$ and enrichments of REE. 


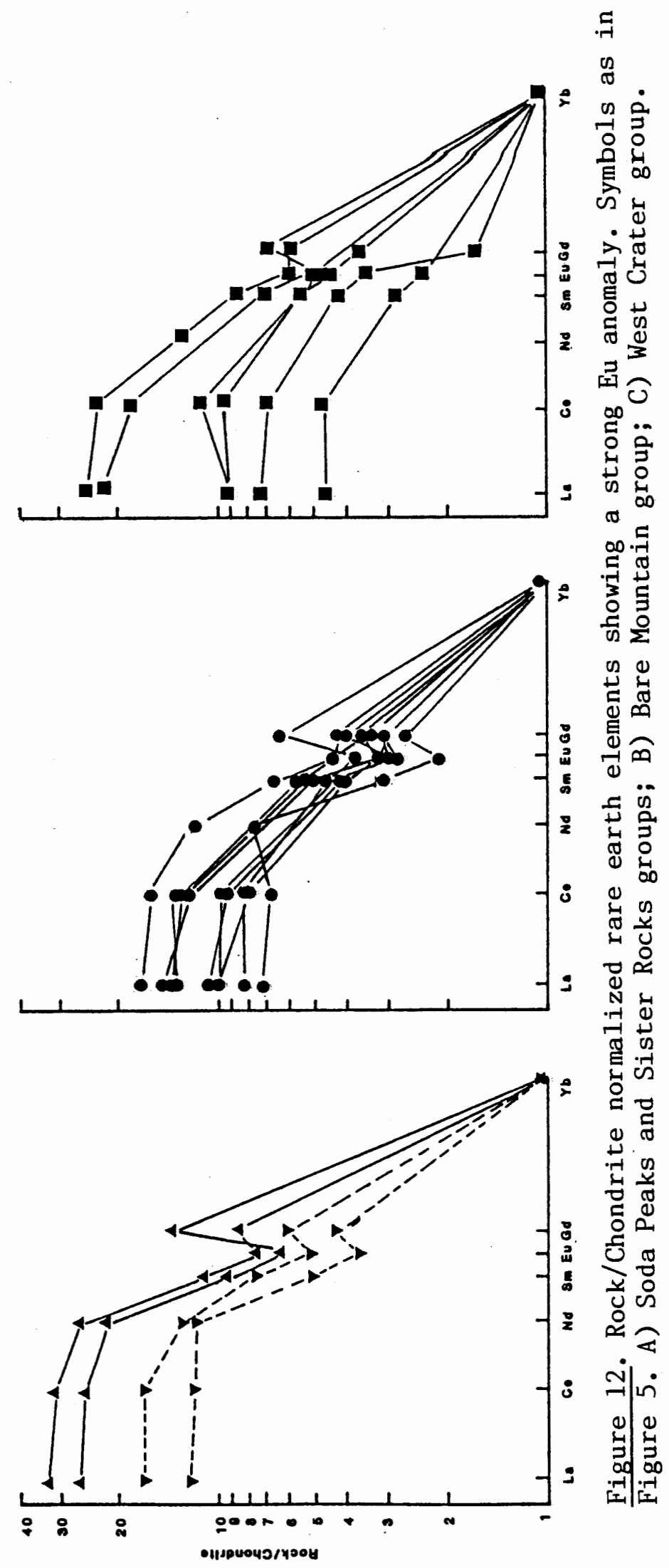


The Sister Rocks, Soda Peaks, and Bare Mountain chemical groups are compared to basalts and mafic andesites of the Oregon High Cascade Range (Wise, 1969; White and McBirney, 1979; Figures 8 and 9). In comparison, the Sister Rocks and Soda Peaks chemical groups contained higher values of $\mathrm{K} 0, \mathrm{MgO}$, and $\mathrm{P} 0$ than the Oregon rocks (Figures 8 and 9). The Bare Mountain chemical group has a slightly higher MgO content than the Oregon rocks while K 0 and $P 0$ contents are similar (Figures 8 and 9). * * 225

$\mathrm{FeO} / \mathrm{FeO}+\mathrm{MgO}$ values are lower for the basalts and mafic andesites of the map area (Figure $8 \mathrm{C}$ ). The West Crater chemical group contains lower values of $\mathrm{K} O$ and SiO than the average 22 andesite of the Oregon Cascade Range while $\mathrm{MgO}$ and $\mathrm{P} 0$ are higher (White and McBirney, 1979; Figures 8 and 9). $\mathrm{FeO} / \mathrm{FeO}+\mathrm{MgO}$ values are similar (Figure $8 \mathrm{C}$ ). White and McBirney (1979) showed that over time, the Cascade Range lavas become depleted in silica and iron oxide while $\mathrm{Na} O$ increases. In the West Crater-Soda Peaks area, 2 silica content has increased over the last 360,000 years (Figure 13). Iron oxide and soda show little variation but follow trends similar to those shown by White and McBirney, (1979; Figure 13). In the West Crater-Soda Peaks area $\mathrm{K} 0, \mathrm{P} 0$ and LREE show a strong decrease over time (Figure 13). $2 \quad 25$

White and McBirney (1979) explained the trends observed in the central Oregon Cascade Range in a three stage model of crystal-liquid equilibration, including 1) progressive depletion 


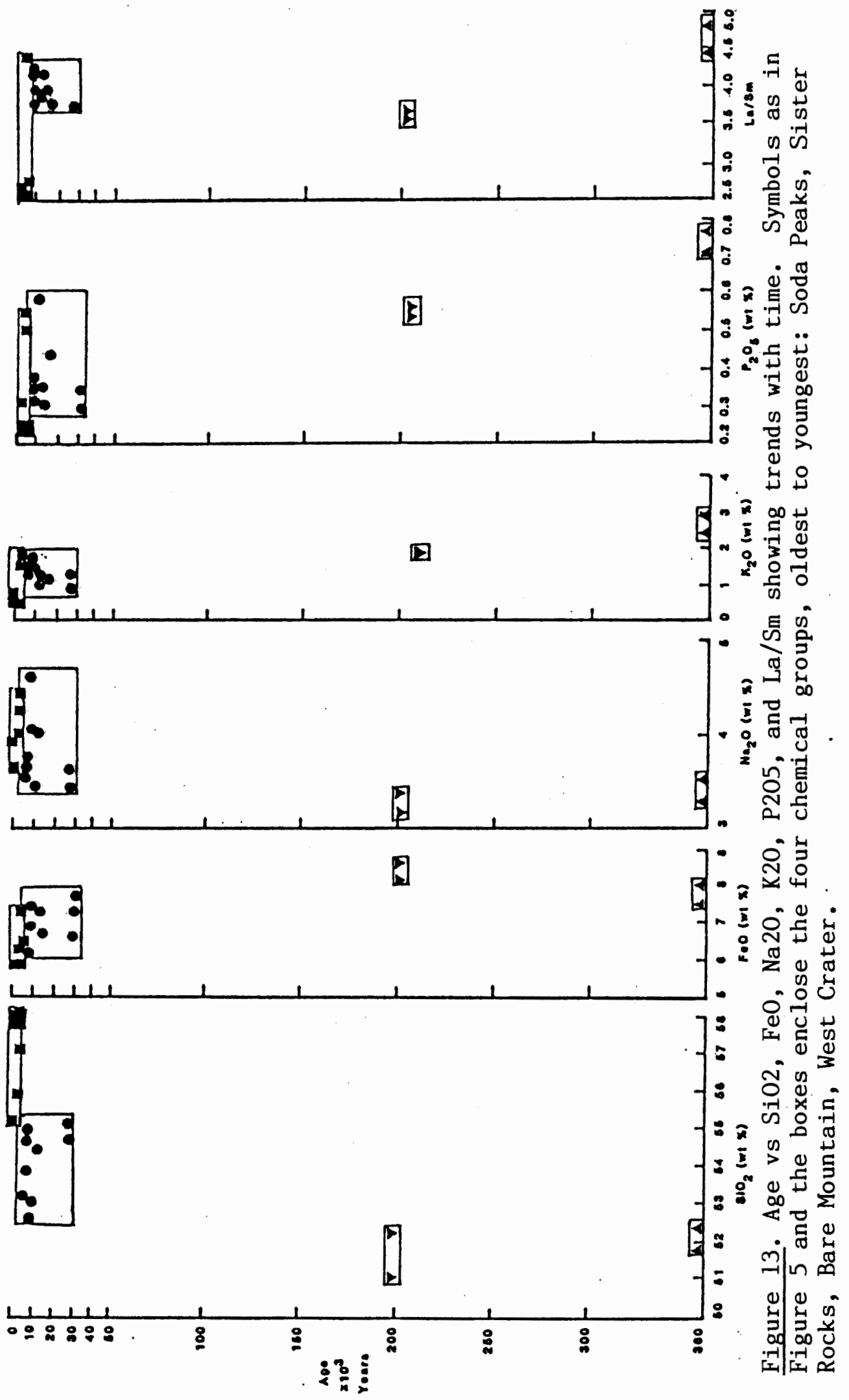


of a source region in the mantle; 2) re-equilibration of each batch of magmá possibly near the base of the lithosphere; and 3) subsequent differentiation at a high level in the crust. Variation diagram of samples from the study area show several interesting relationships. With the exception of Sc versus Co, the trends fall in broad bands lacking welldefined linear relationships. $\mathrm{K} O$ appears to vary inversely with respect to silica (Figure $8 \mathrm{~A}$ ); a trend that is not expected in andesites and basalts (Gill, 1980) since normal fractionation generally crystallizes $\mathrm{K}$ 0-poor minerals first, such as olivine, enriching the melt in $\mathrm{k} 0$. In the suite of 2

rocks of the area Sc shows a covariant relationship with Co (Figure 10B). As with $\mathrm{KO}$ versus $\mathrm{SiO}$, the trend is opposite of what is to be expected during fractionation (Bowen, 1956). Phosphorus is an incompatible element and therefore increases as silica increases (Frey, 1980). In this study $P$ O decreases with increasing silica (Figure 8B).

Several hypotheses may explain the occurence of the chemical groups and their trends in the variation diagrams. The most probable hypotheses are:

1) The rocks may be the result of separate unrelated magmatic bodies localized in the map area.

2) The rocks may have been a result of partial melting of a heterogeneous source.

Any hypothesis regarding the evolution of the magma or magmas in the West Crater-Soda Peaks area has to account for the 
variations through time, the variation diagram trends and the following general observations:

1) The scattered clusters of chemical groups which have erupted from numerous volcanic centers, suggesting several magma sources or paths of differentiation.

2) Bare Mountain and possibly the West Crater volcanic centers show a possible differentiation trend.

3) The most primative rocks, those with low SiO and high $\mathrm{MgO}$ content, appear to have the most differentiated trace elments (Figure 9,10, and 12).

4) On the basis of a sharp Eu anomaly with $\mathrm{Eu} / \mathrm{Eu}$ values between 0.56 and 1.3 (Figure 12), plagioclase fractionation at low pressure appears to be a dominant process removing plagioclase from the melt or melts (Cox et a1., 1979).

Without isotope and melting studies, the limited data available in this study makes drawing a confident conclusion on petrogenesis impossible.

In summary, the High Cascade lavas in the West Crater-Soda Peaks area consist of high-alumina calc-alkaline basalt of destructive plate margins and medium to low-K mafic andesite and andesite. The rock units can be divided into four chemical groups summarized in Table IV. Compared to other High Cascade volcanic rocks, the rocks of the area $\underset{*}{\text { are }} \underset{*}{*}$ enally higher in $\mathrm{MgO}$ and $\mathrm{PO}$, while $\mathrm{KO}$ and $\mathrm{SiO}$ vary. $\mathrm{FeO} / \mathrm{FeO}+\mathrm{MgO}$ values for the 25 2 2 


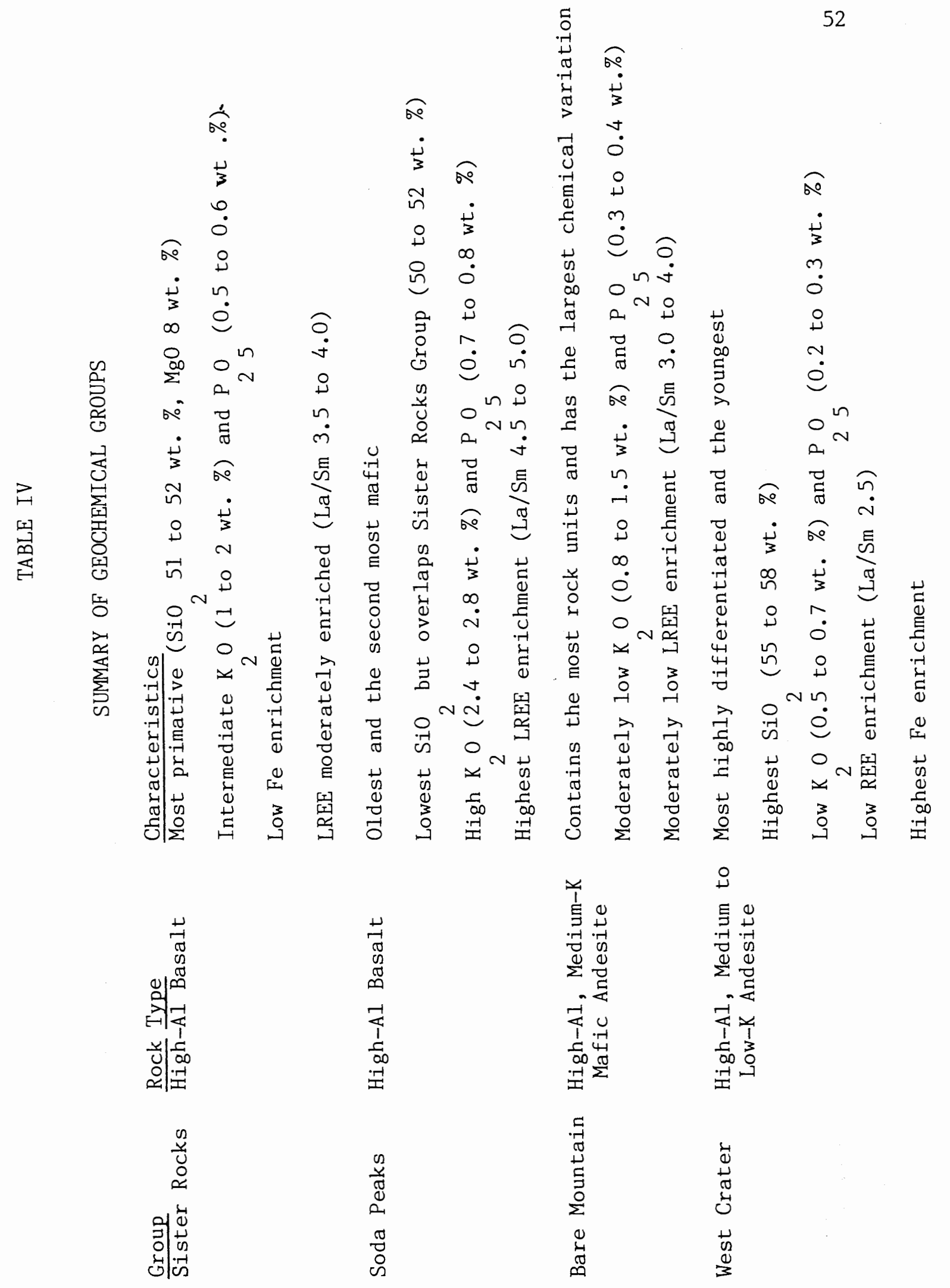


rocks of the map area are generally similar or slightly lower than the other Cascade rocks.

Over the last 360,000 years, SiO and $\mathrm{Na} O$ content have * 22

increased while $\mathrm{K} 0, \mathrm{P} 0, \mathrm{Fe} 0$ and trace element contents have $2 \quad 25$

decreased. The volcanic rocks of the map area are probably the result of several magmatic processes, differentiation of unrelated sources or partial melting of a heterogeneous source. 


\section{CHAP'TER VI}

\section{SUMMARY}

Fifteen rock units were defined in the map area, ranging from surficial deposits to basaltic and andesitic lava flows to volcaniclastic sedimentary rocks and diorite intrusions.

The oldest unit is the Ohanapecosh Formation with an age of 36 to $28 \mathrm{~m}$. y. The formation underlies the entire study area and is composed of interstratified laharic breccias, tuffs, volcaniclastic sedimentary rocks, and lava flows of basalt and andesite. The maximum exposed thickness of the formation is 458 meters.

Many intrusions of Tertiary age cut the Ohanapecosh Formation. These intrusions are fine-grained basaltic and andesitic dikes, plugs and sills. The trends of the intrusions are generally northwest or northeast with a few trending northsouth and east-west. The intrusions average 3 m-wide and are rarely traceable beyond the outcrop due to forestation.

Four groups of High Cascade volcanic rocks are recognized in the area; they are in order of decreasing age: the Soda Peaks group, the Sister Rocks group, the Bare Mountain group and the West Crater group.

The Soda Peaks group consists of one rock unit, the basalt of Soda Peaks. Dated at 360,000 years of age, the unit is composed of two pyroxene basalt lava flows from 9.2 to 33 m-thick 
containing 50 to 52 weight percent SiO .

The basalt of Sister Rocks composes the one unit Sister Rocks group. The unit is estimated to be older than 10,000 years and consists of a 14 m-thick pyroxene basalt lava flow and a $2 \mathrm{~m}$ wide basalt dike each with 52 weight percent $\mathrm{SiO}_{2}$.

The third group, the Bare Mountain group, consists of seven rock units in stratigraphic order: The andesites of Calamity creek, The andesite of Timbered Peak, the andesites of Siouxon Creek, the andesites of South Soda Peaks, the andesites of Bare Mountain, the andesite of Chinook Creek, and the andesites of Puny Creek. The andesites of Càlamity Creek are estimated to be greater than 10,000 years old and consist of two lava flows 20 ans 22 m thick. The andesite of Timbered Peak is considered preglacial ( $>10,000$ years) and consists of a $31 \mathrm{~m}-$ thick flow of olivine mafic andesite with 55 weight percent SiO. The andesites of Siouxon Creek occur as two 15 and 23 m-thick flows of olivine mafic andesite with 54 weight percent SiO. The age of the unit is estimated to be preglacial $(>10,000$ years). Four overlapping olivine mafic andesite lava flows averaging $28 \mathrm{~m}$ thick compose the andesite of South Soda Peaks. They have 53 weight percent $\mathrm{SiO}_{2}$ and are estimated to be close to 10,000 years old because of overlying glacial till. The andesites of Bare Mountain is the largest rock unit in the group consisting of multiple flows of olivine basalt to mafic andesite with a maximum combined thickness of 84 meters. The unit is estimated to be 
interglacial in age, between 20,000 and 10,000 years ago and contains 51 to 53 weight percent SiO . Sometime near 7,700 years 2 ago a hornblende andesite tephra was explosively erupted from Bare Mountain creating a $60 \mathrm{~m}$-deep, $300 \mathrm{~m}$-wide crater and blanketing the area with scoria to a minimum depth of 10 meters. The andesite of Chinook Creek is a post-glacial $(<10,000$ years) 55 m-thick lava flow of olivine andesite containing 54 weight percent silica. The last unit of the Bare Mountain group is the $38 \mathrm{~m}$-thick andesite of Puny Creek. The unit is a post-glacial olivine mafic andesite containing 54 weight percent $\mathrm{SiO}_{2}$ The final High Cascade group is the West Crater group consisting of two rock units, the andesite scoria cone of Hackamore Creek and the andesite of West Crater. The andesite scoria cone of Hackamore Creek, dated at 8,000 years is a $15 \mathrm{~m}-$ high scoria cone composed of pyroxene andesite scoria containing 58 weight percent $\mathrm{SiO}_{2}$. The andesites of West Crater are composed of two pyroxene andesite lava flows 26 and $58 \mathrm{~m}$ thick and a $54 \mathrm{~m}$-high hornblende andesite dome containing 56 to 58 weight percent $\mathrm{SiO}_{2}$. The age of the unit is less than 7,700 years.

Surficial deposits in the area consist of up to 2 meters of glacial till and colluvium, estimated to be between 20,000 and 10,000 years old, and of the scoriaceous tephra of the Bare Mountain and Hackamore Creek High Cascade volcanic units.

The High Cascade volcanic lavas in the map area are highalumina calc-alkaline basalts and andesites. On the basis of 
major and trace-element chemistry, the rock units are divided into four chemical groups, the Soda Peaks chemical group, the Sister Rocks chemical group, the Bare Mountain chemical group, and the West Crater chemical group.

Over the last 360,000 years $\mathrm{K}_{2} \mathrm{O}_{2} \mathrm{P}_{2} \mathrm{O}_{5}, \mathrm{FeO}$ and trace element contents have decreased while $\mathrm{SiO}$ and $\mathrm{Na} O \mathrm{O}$ contents have 22 increased. The volcanic rocks of the map area are probably the result of several magmatic processes, differentiation of unrelated sources or the partial melting of a heterogeneous source.

The map area is deformed into a series of broad anticlines and synclines plunging to the northwest and estimated to be of Tertiary age. Although lying along the southward projection of the St. Helens seismic zone, no large-scale faulting was observed. The density of the volcanic centers is of undeterminable significance but may indicate a crustal weakness. The intrusions strike chiefly northwest and northeast parallel to the regional structural trend of the Cascade Range. 


\section{REFERENCES CITED}

Allen, J. E., 1965, The Cascade Range volcano-tectonic depression in Oregon: Trans. of the Lunar Geol. Field Conf., Bend, Ore., p.21-23.

Baxter, A. N., 1976, Geochemistry and petrogenesis of primative alkali basalt from Mauritius, Indian Ocean: Geol. Soc. Amer. Bul1. v. 87, p. 1028-1034.

Bowen, N. L., 1956, The evolution of igneous rocks: Dover Publications Inc., New York 332 p.

Carver, R. E.,1971, Proceedures in sedimentary petrology: Wileyinterscience, New York, 635 p.

Cox, K. G.; Bel1, J. D. and Pankhurst, R. J., 1979, The interpretation of igneous rock: George Allen and Unwin, London, $450 \mathrm{p}$.

Crande11, D. R. and Miller, R. D., 1974, Quaternary stratigraphy and extent of glaciation in the Mount Rainier region, Washington: U. S. Geological Survey Prof. Paper 847, 59 p.

Frey, F. A., 1980, Application of Neutron activation analysis in mineralogy and petrology:[in] Short course in neutron activation analysis in the geosciences, [ed.] Muecke, G. K.; Mineralogical Assoc. of Canada Short Course handbook v. 5, p.167-210.

Frizzell Jr., V. A., and Vance, J. A., 1983, Cenozoic volcanism of the Cascades of Washington: EOS (Transact. of the Amer. Geophysical Union), v. 64, n. 45, p. 866.

Gast, P. W., 1968, Trace element fractionation and the origin of tholeiitic and alkaline magma types: Geochim. et Cosmochim. Acta, v. 32, p.1027-1086.

Gill, J. B., 1980, Orogenic andesites and plate tectonics: Springer-Verlag, New York, 390 p.

Goddard, E. N.; Trask, P. D.; DeFord, R. K.; Rove O.N.; Singewald Jr., J. T. and Overbeck, R. M., 1980, Rock color chart: Geol. Soc. Amer. 
Hammond, P. E., 1979, A tectonic model for evolution of the Cascade Range: [in] Cenozoic paleogeography of the western United States; Pacific section of Economic Paleontologists and Mineralogists, p. 219-238.

, 1980, Reconnaissance geologic map and cross-sections of southern Washington Cascade Range: Portland State University Department of Earth Sciences, Portland, Oregon; map, crosssections and text, $31 \mathrm{p}$.

Hooper, P. R.; Reidel, S. A.; Brown, J. G.; Holden, G. S.; Kleck, W. D.; Sunstrom, C. E.; Taylor, T. L., 1981, Major element analyses of Columbia River Basalt, Part I: Basalt Research Group Washington State University, Pullman, Washington, 59 p.

Irvine, T. N. and Baragar, R. A., 1971, A guide to the classification of common volcanic rocks: Canadian Journal of Earth Sciences, v. 8, p. 523-548.

Peck, D. L.; Griggs, A. B.; Schlicker, H. G.; Wells, F. G. and Dole, H. M., 1964, Geology of the central and northern parts of western Cascade Range in Oregon: U. S. Geol. Survey Prof. Paper 449, $56 \mathrm{p}$.

Taylor, E. M., 1981, Volcanic and volcaniclastic rocks on the east flank of the central Cascade Range to the Deschutes River, Oregon: [in] Geologic field trips in western Oregon and southwestern Washington: Oregon Department of Geol. and Min. Industries Bu11. 101, p. 1-7.

Weaver, C. S. and Smith, S. W., 1981, The St. Helens seismic zone; a major crustal fault zone in western Washington (abstr.): EOS (Transactions of the Amer. Geophysical Union), v. 62, n. 42 , p. 966 .

White, C. M. and McBirney, A. R., 1979, Some quantitative aspects of orogenic volcanism in the Oregon Cascades: Geol. Soc. of Amer. Mem. 152, p. 369-388.

Wise, W. S., 1969,Geology and petrology of the Mount Hood area; a study of High Cascade volcanism: Geol. Soc. Amer. Bull. v. 80 , p. 969-1006.

, 1970, Cenozoic volcanism in the Cascade Mountains of southern Washington: Wash. Div. of Mines and Geology Bull. $60,45 \mathrm{p}$.

Wood, D. A.; Jordon, J. L. and Treuil, M., 1979, A reappraisal of the use of trace elements to classify and discriminate between magma series in different tectonic settings: Earth and Planetary Sci. Letters, v. 45, p. 326-336. 


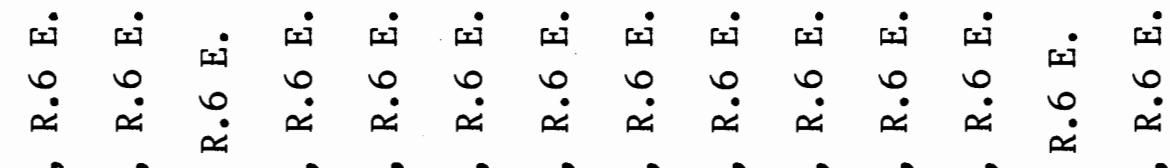

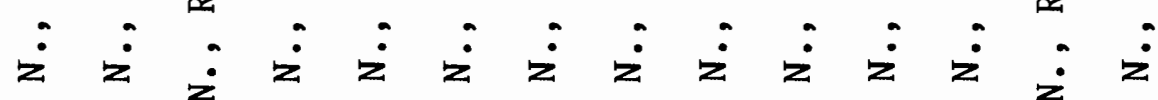

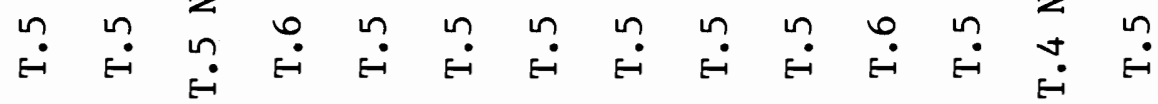

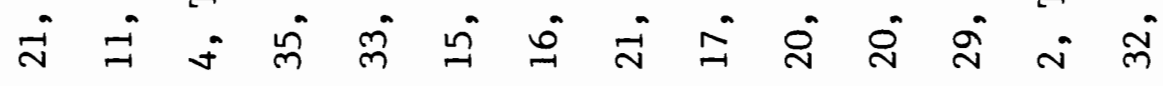

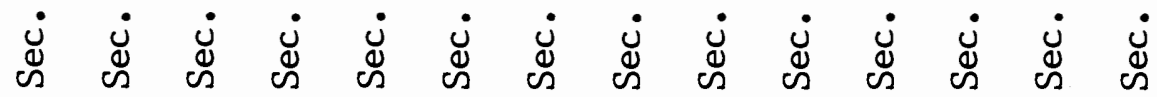

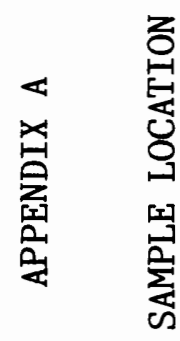

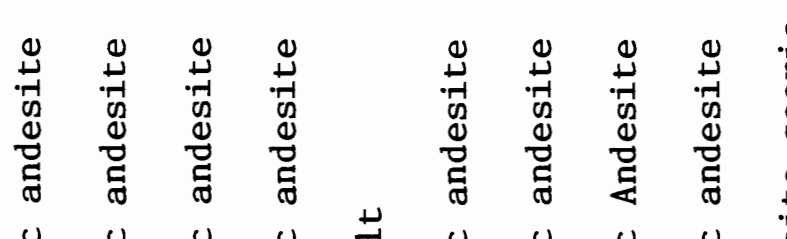

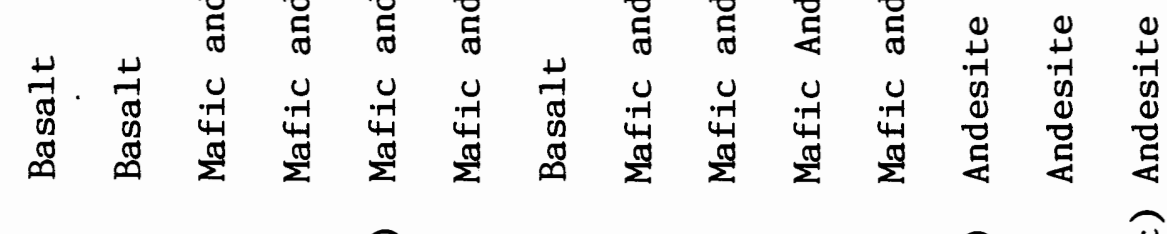

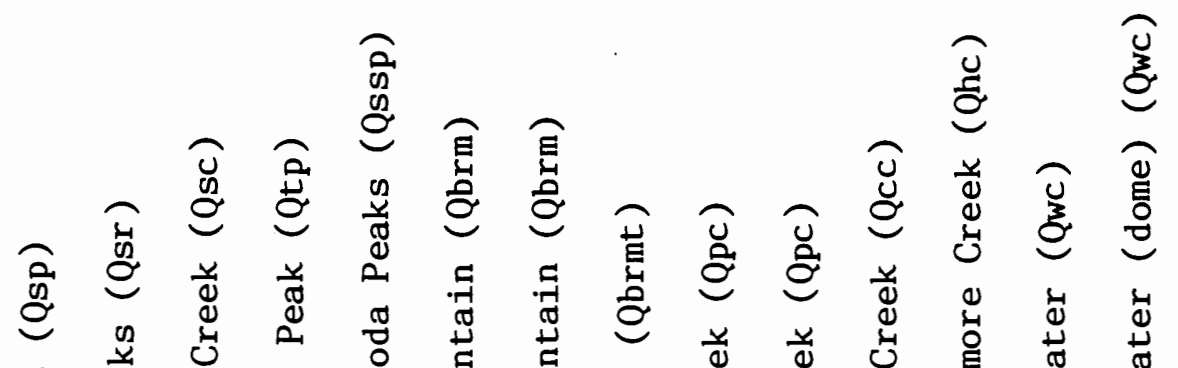

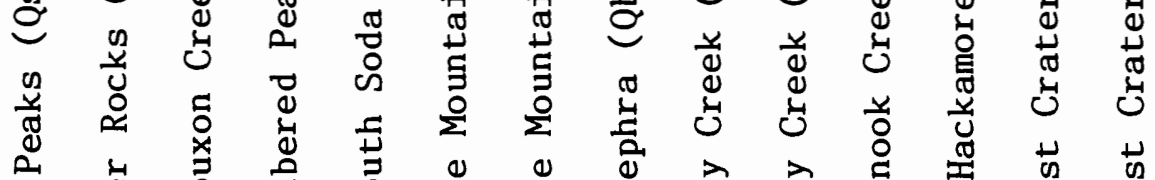
2

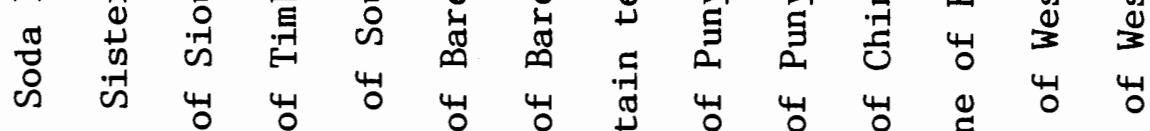
年

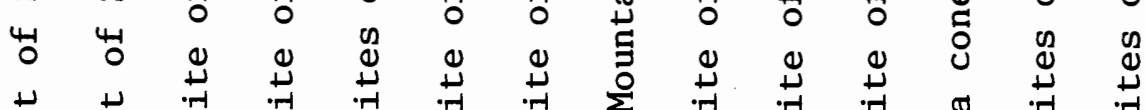

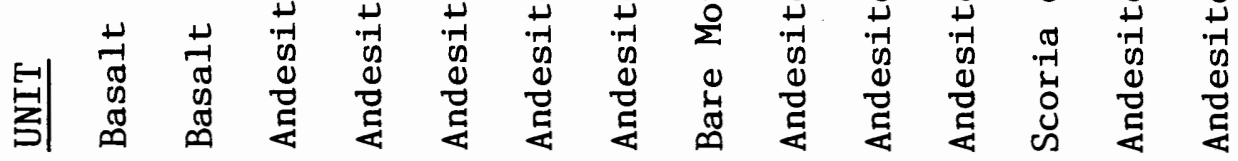
槒- 


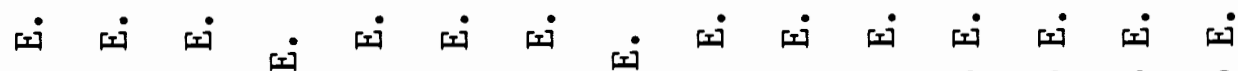

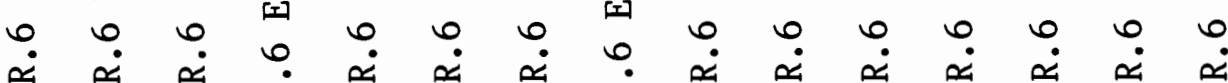

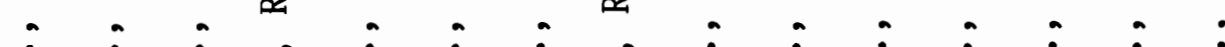
$\dot{z} \quad \dot{z} \quad \dot{z} \quad \dot{z} \quad \dot{z} \quad \dot{z} \quad \dot{z} \quad \dot{z} \quad \dot{z} \quad \dot{z} \quad \dot{z} \quad \dot{z} \quad \dot{z} \quad \dot{z} z$

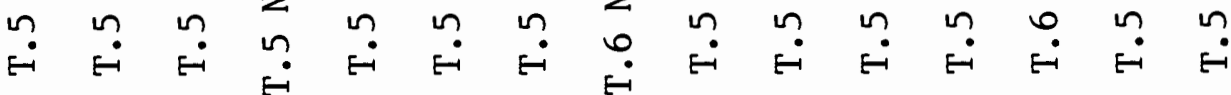
○ ป

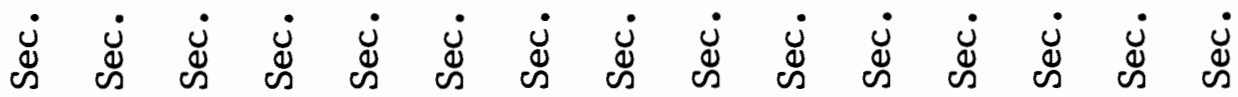

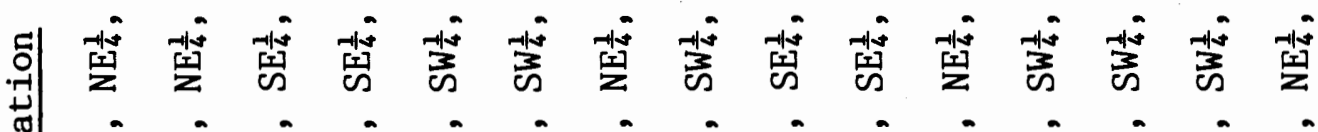

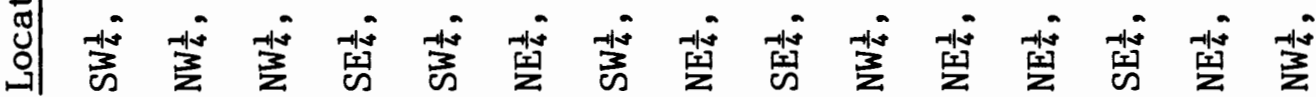

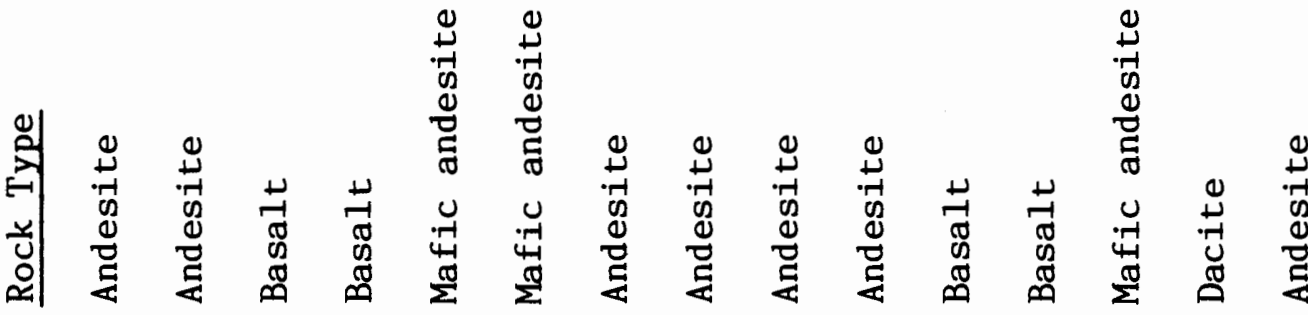

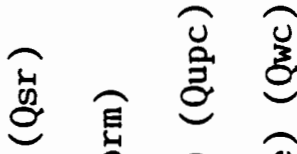

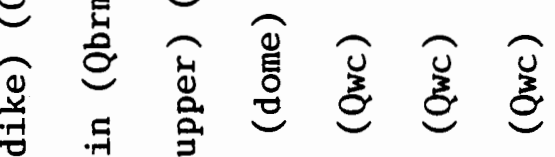

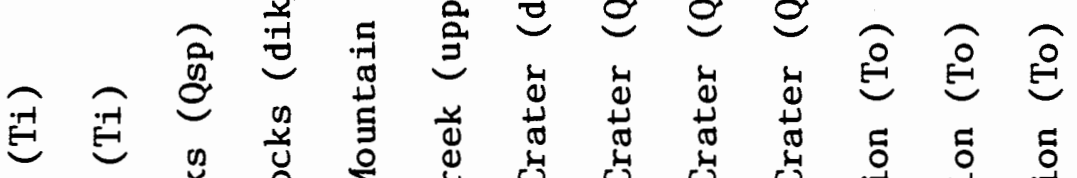

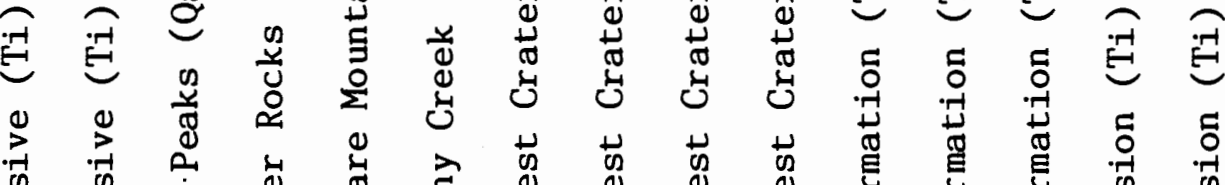

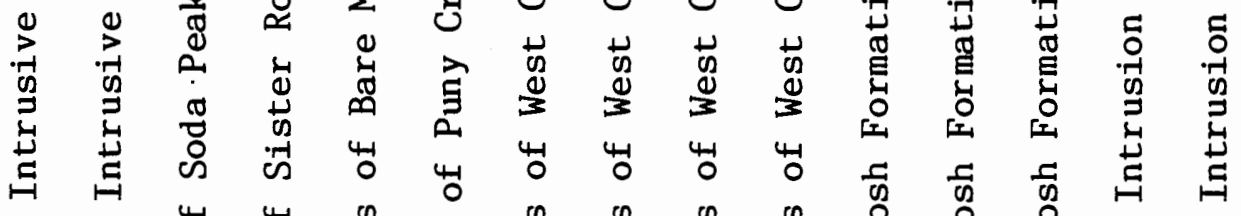

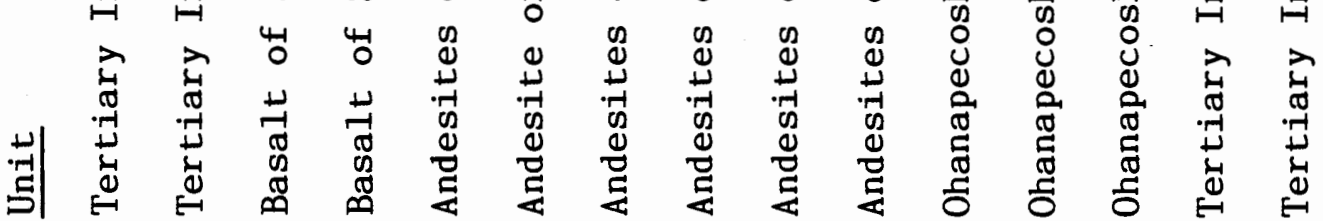
\# 


\begin{tabular}{|c|c|c|c|c|c|c|}
\hline & $\stackrel{0}{-}$ & & $\ddot{m}$ & $\hat{\sim}$ & $\begin{array}{l}0 \\
\dot{N}\end{array}$ & \\
\hline & +1 & & +1 & +1 & $+1+1$ & \\
\hline ○ & $\tilde{0}$ & $\ddot{0}$ & $\begin{array}{l}a \\
\infty \\
\infty\end{array}$ & $\begin{array}{l}\infty \\
\stackrel{\dot{N}}{N}\end{array}$ & $\ddot{n} \dot{m}$ & $\dot{m}$ \\
\hline & $\stackrel{0}{-}$ & & $\stackrel{v}{r}$ & a & $\stackrel{\infty}{-}$ & $\ddot{0}$ \\
\hline & +1 & & $+1+1$ & +1 & +1 & +1 \\
\hline n & 0 & 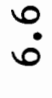 & $\begin{array}{l}\infty \\
\dot{\sigma} \\
\stackrel{\sigma}{\circ}\end{array}$ & ஜே & $\stackrel{\sim}{\infty}$ & $\ddot{0} \dot{\sigma}$ \\
\hline
\end{tabular}

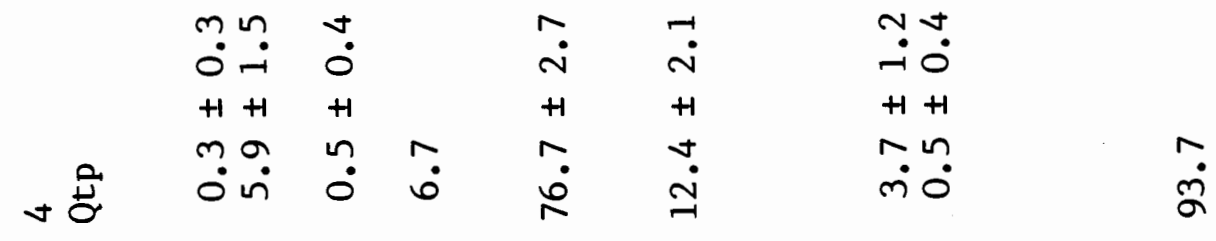

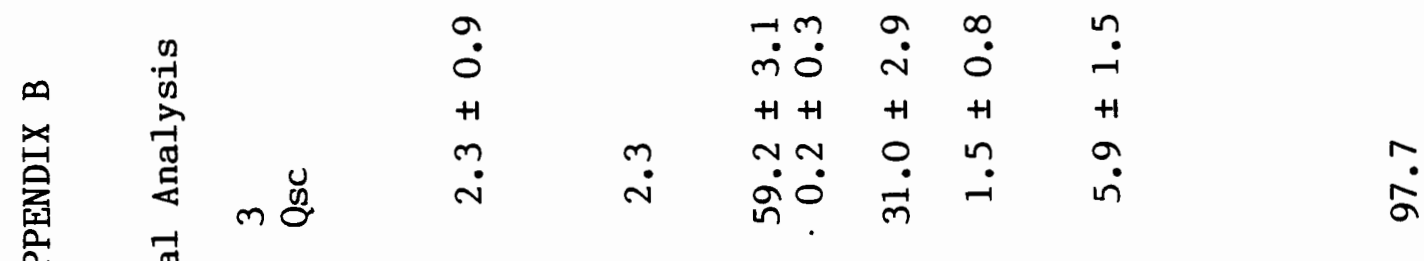

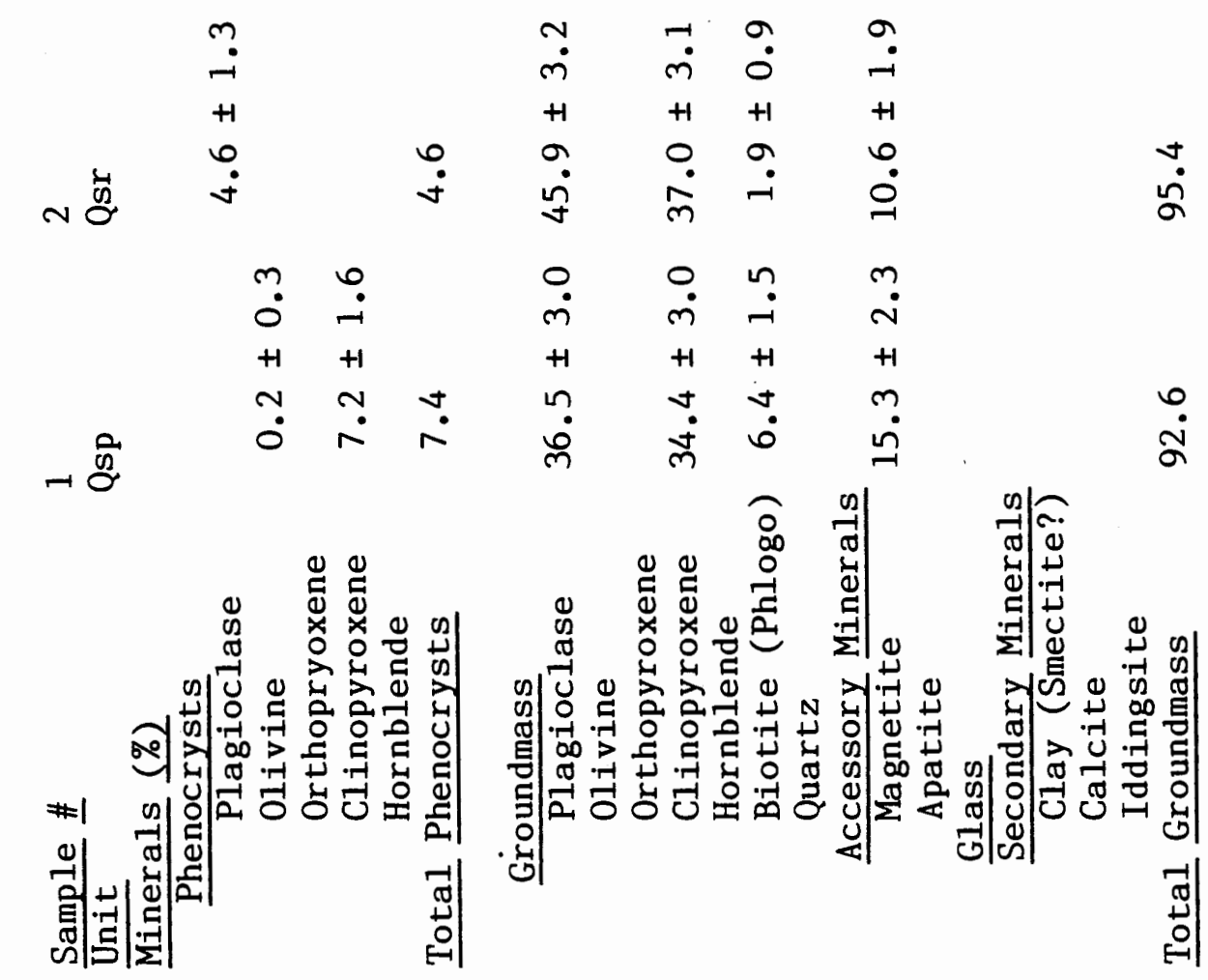




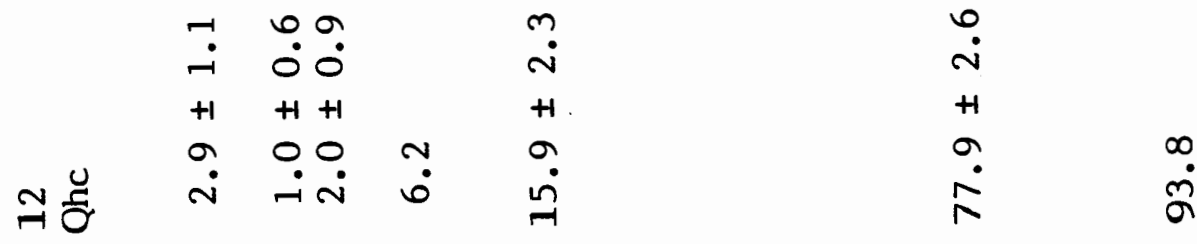

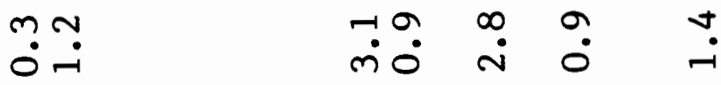

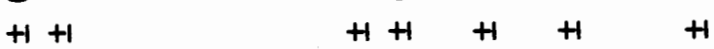

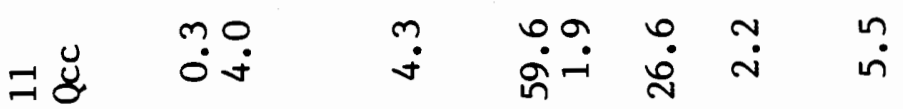

กั

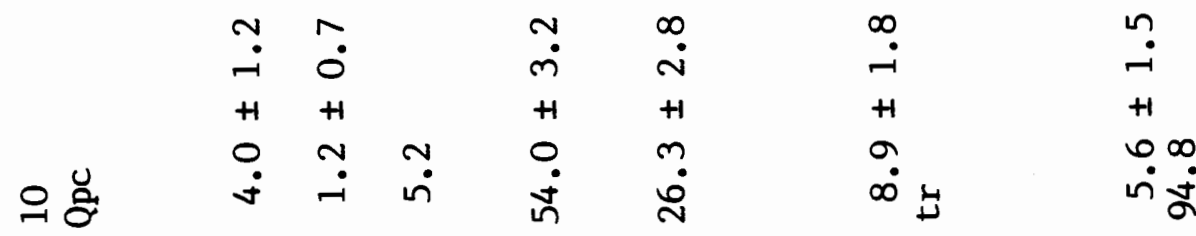

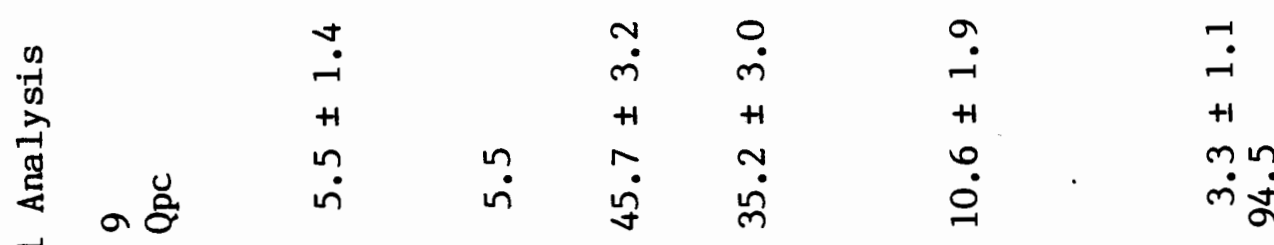

$\frac{\pi}{2}$

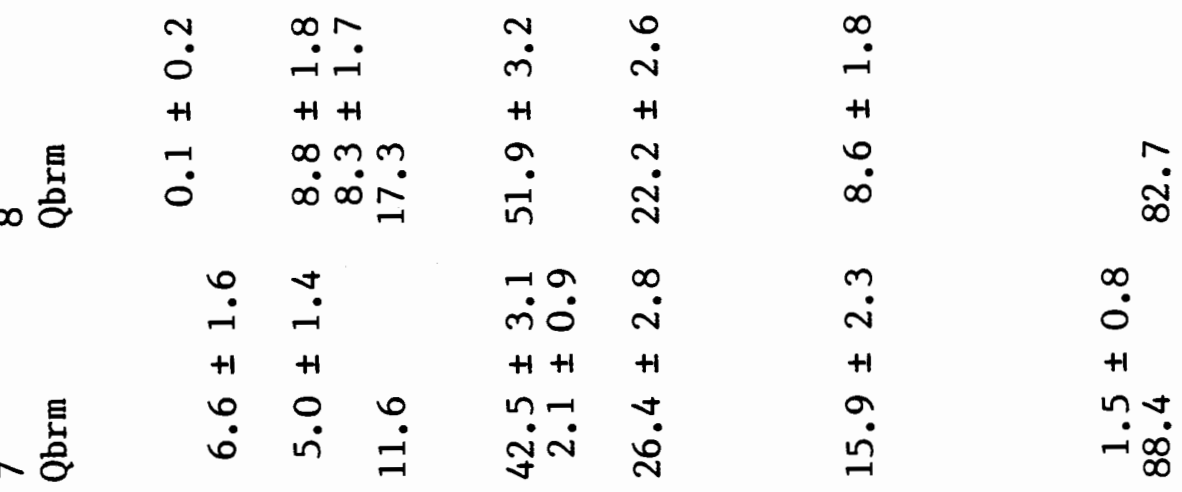

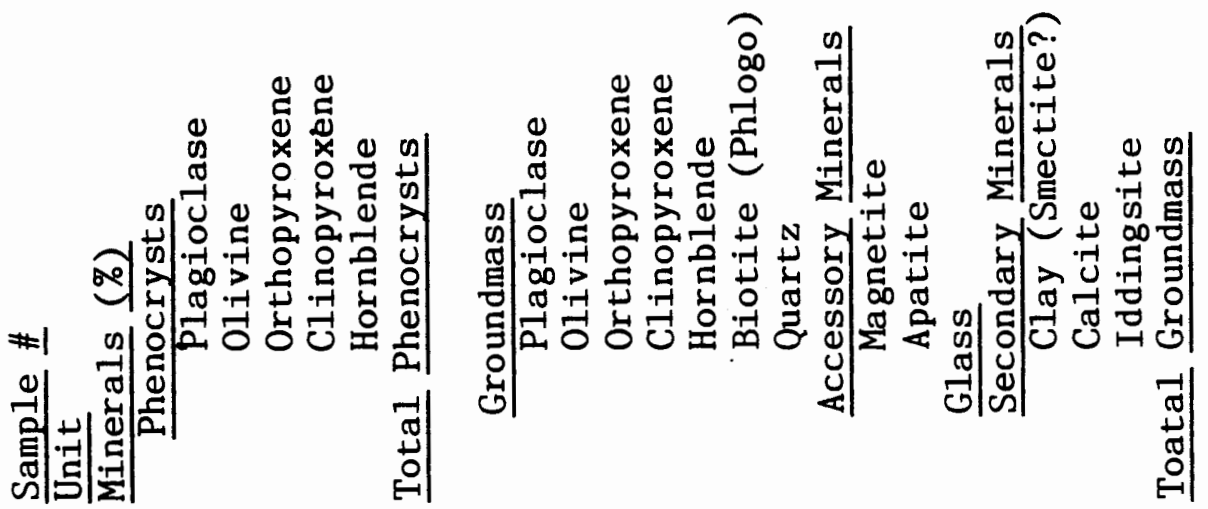




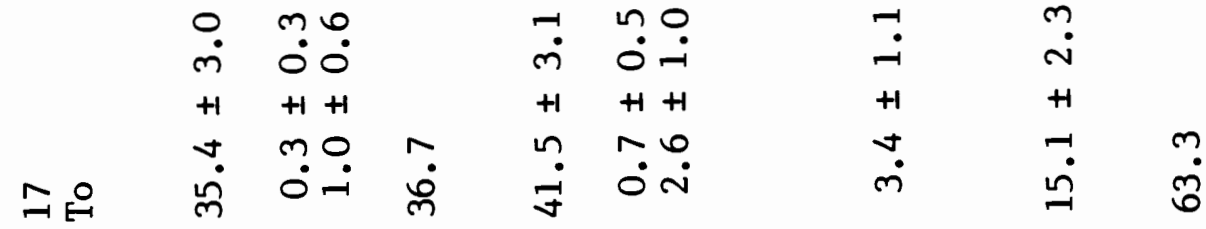

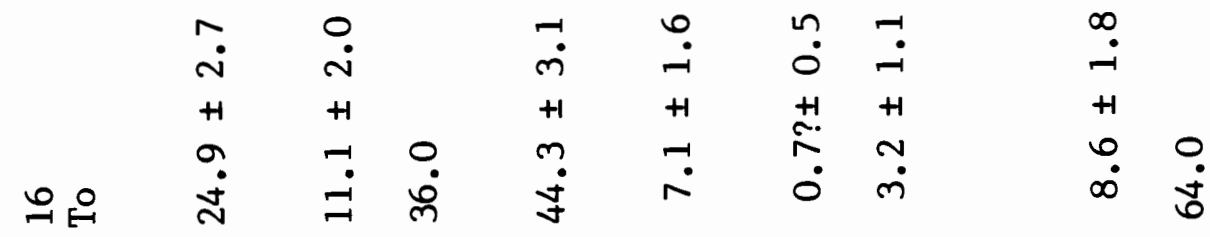

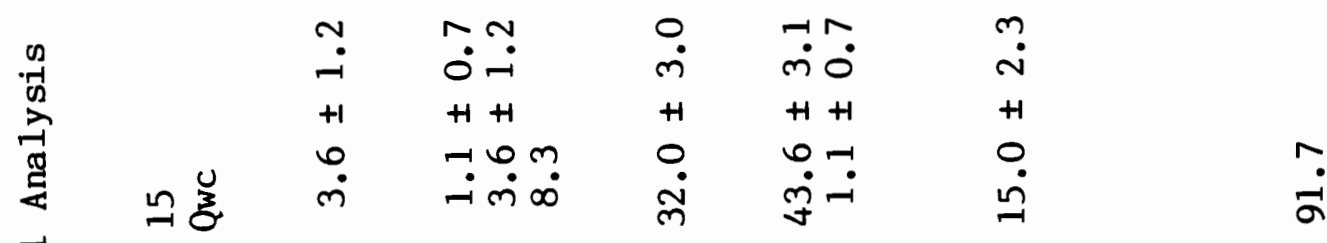

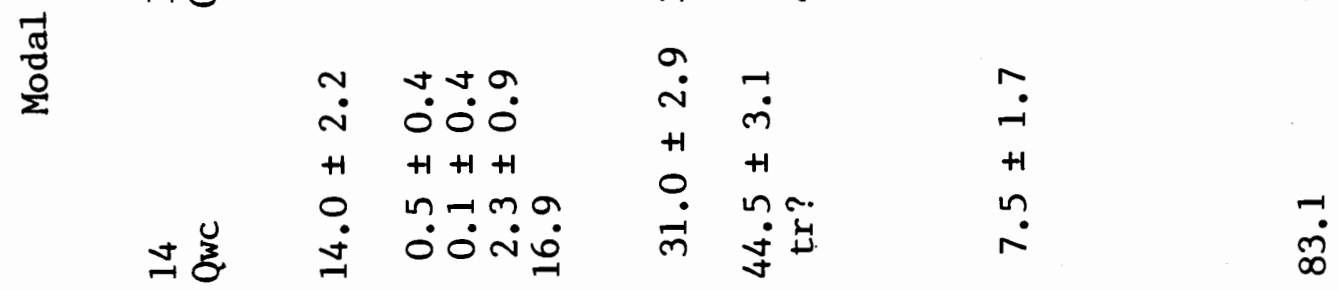

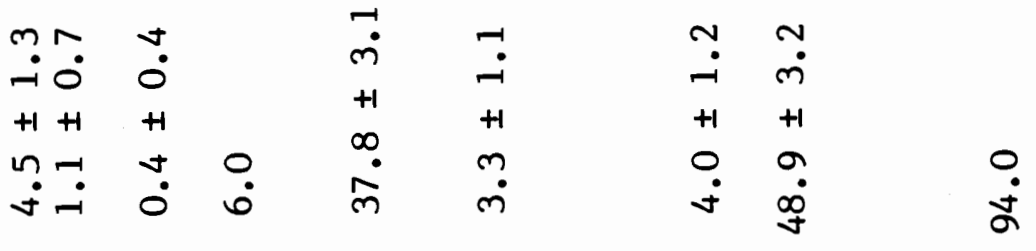

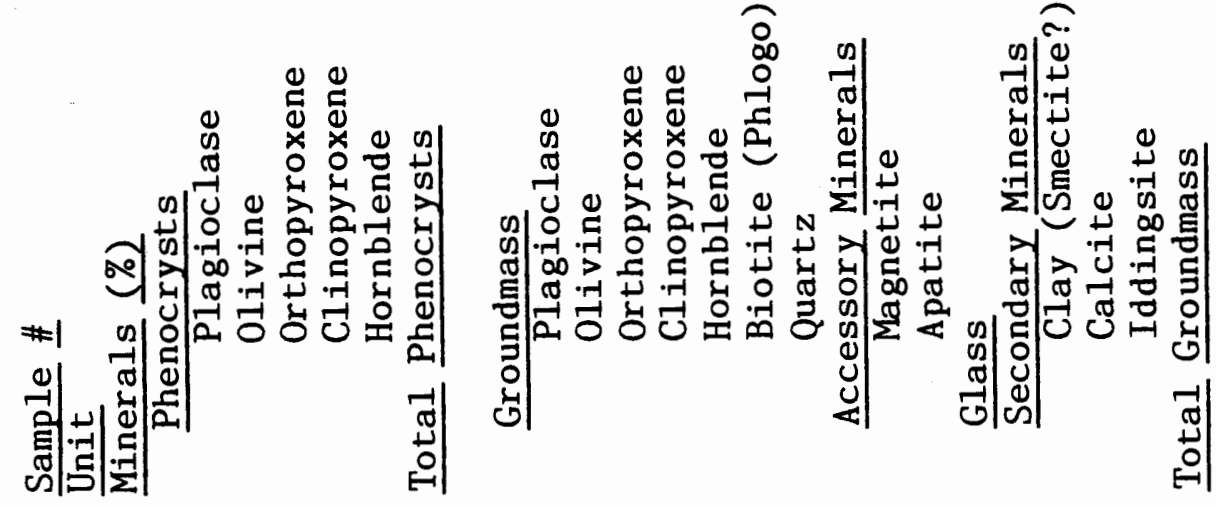




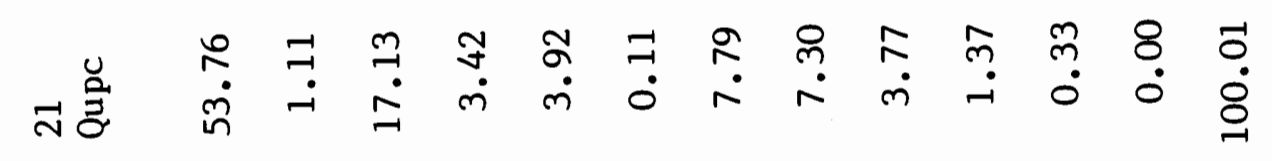

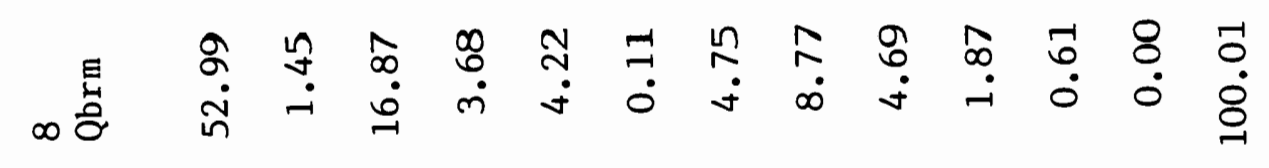
点 芫

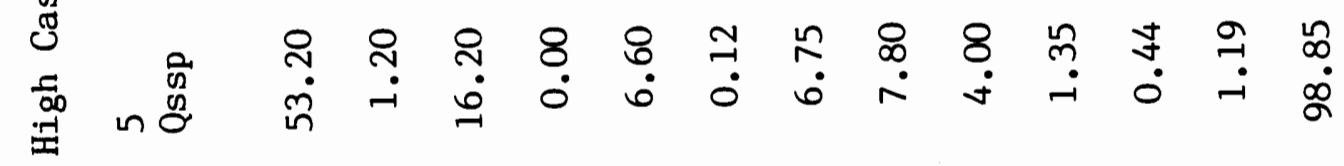

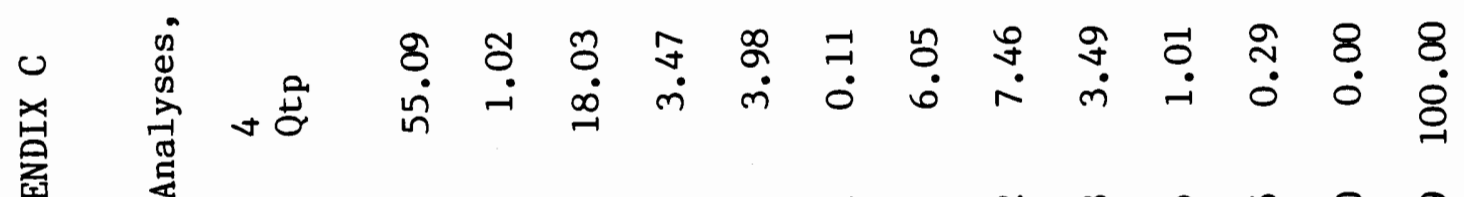

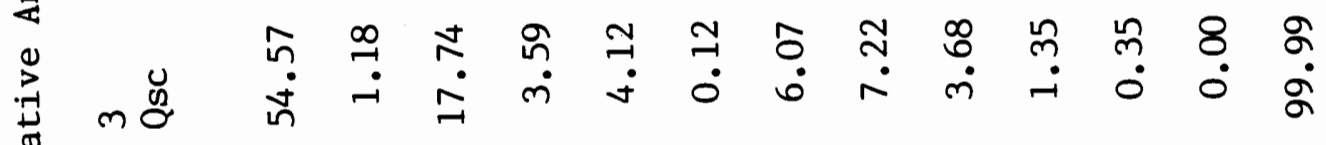
:

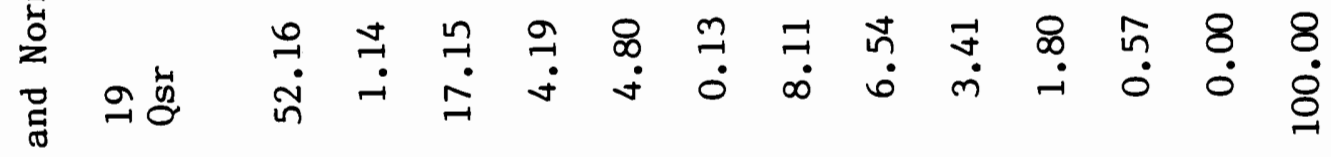

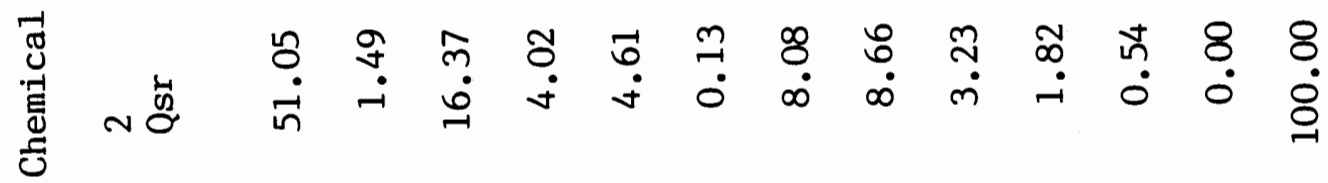

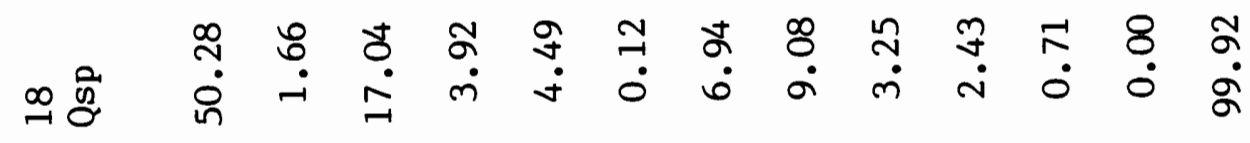

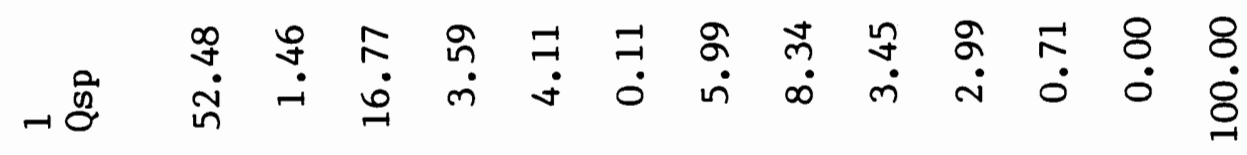

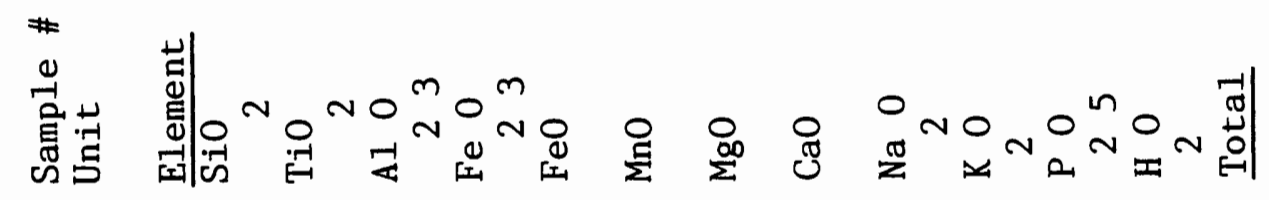




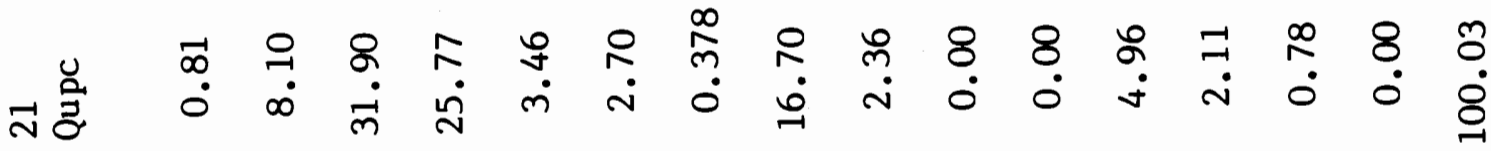

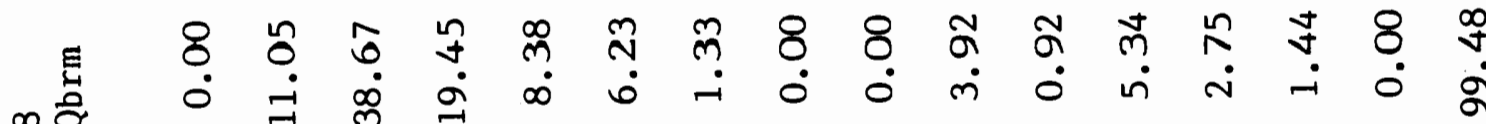

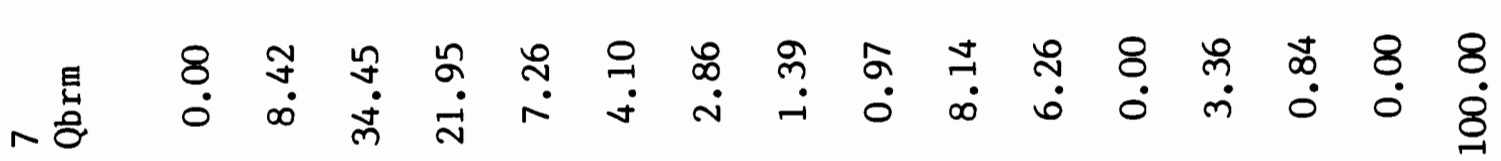
융

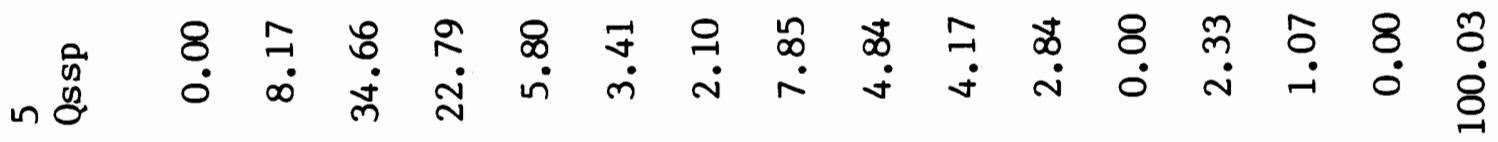

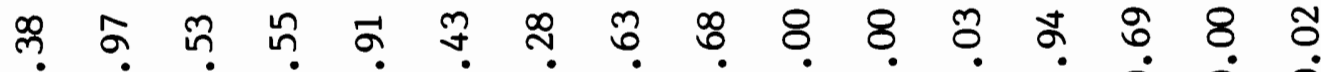
ナ

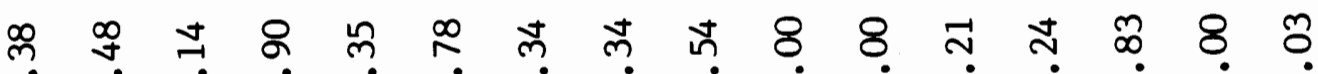

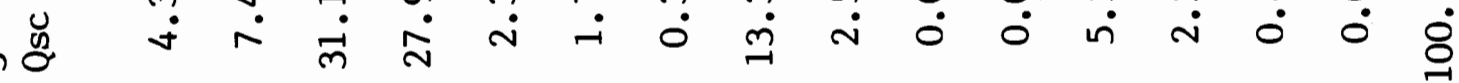
8. ป๋

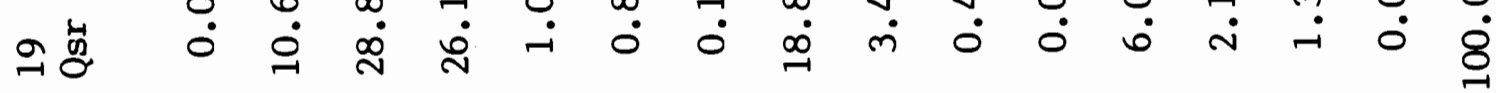

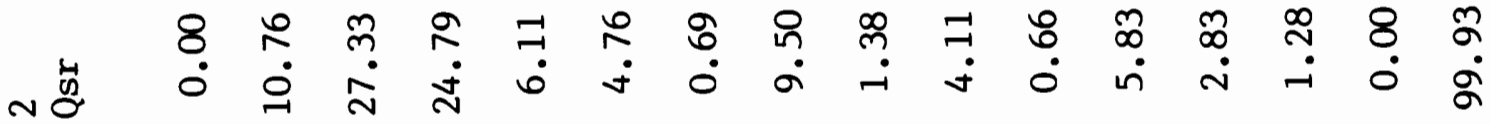

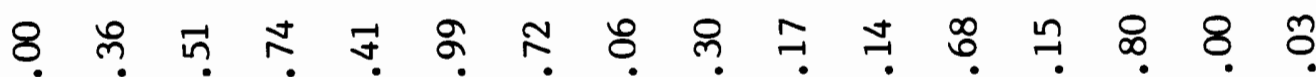

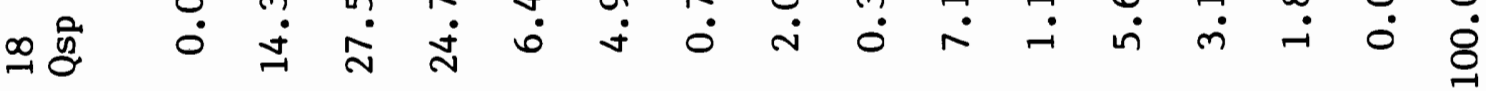
8. กิ ๆ ษ

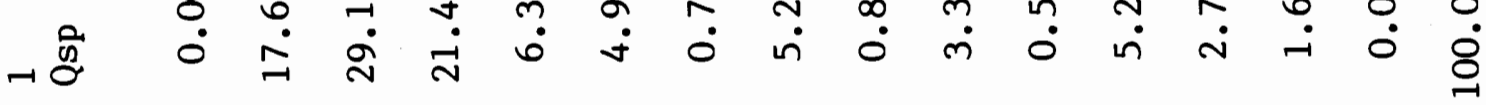

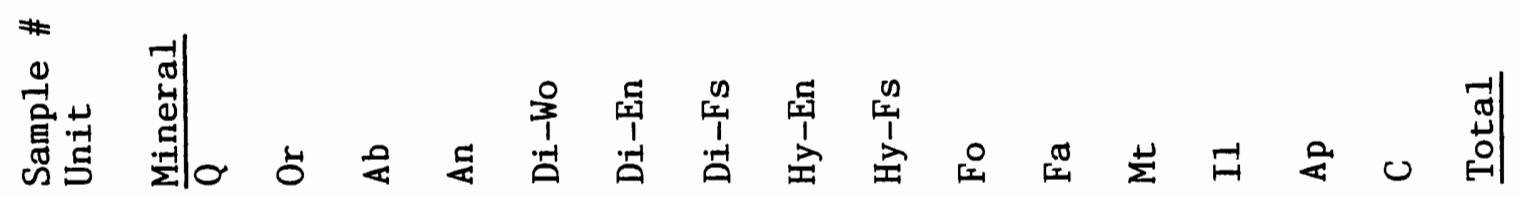




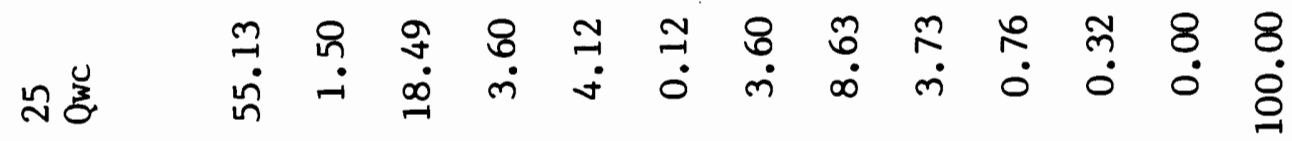

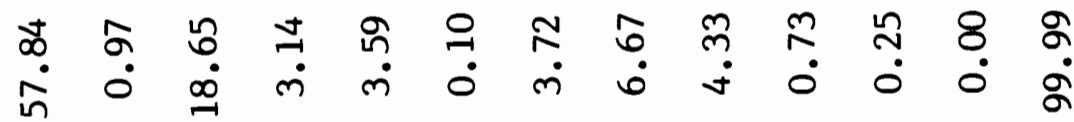
ஜ

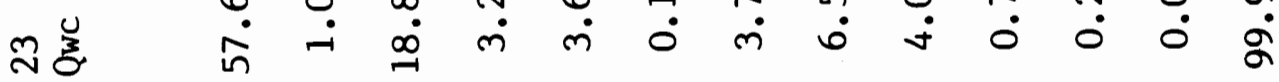

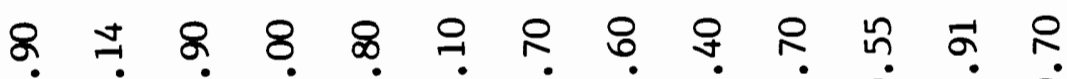

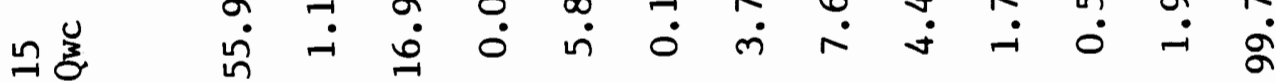

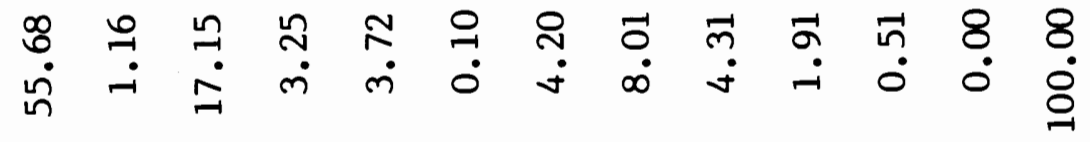
क ने

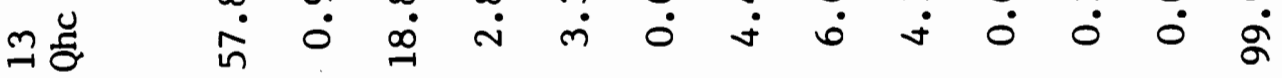

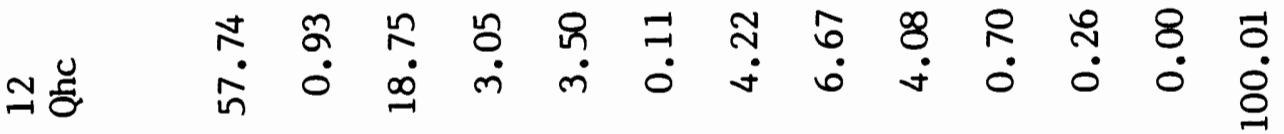

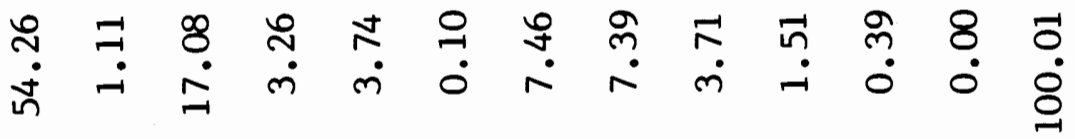
구 우 8 ㅇ a

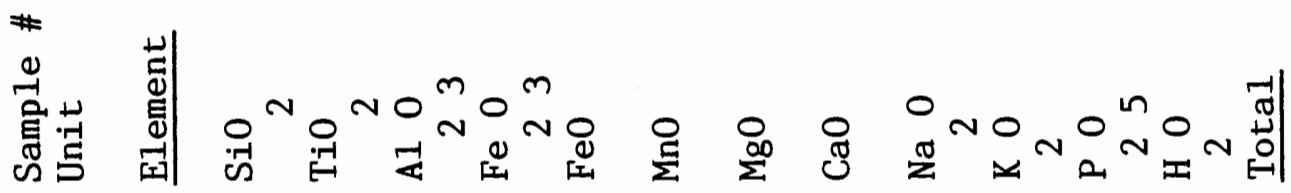




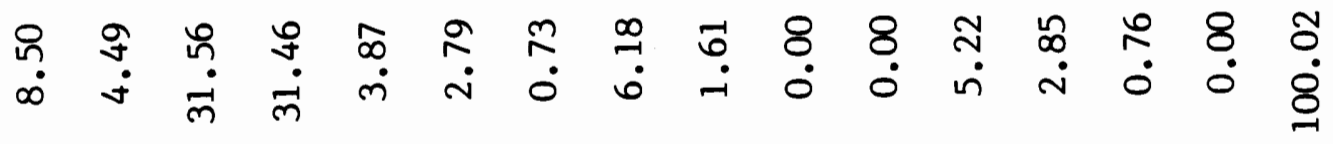

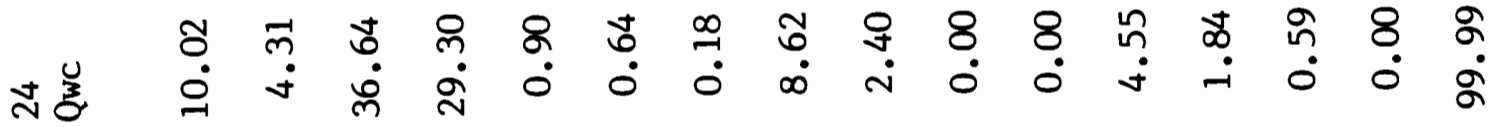

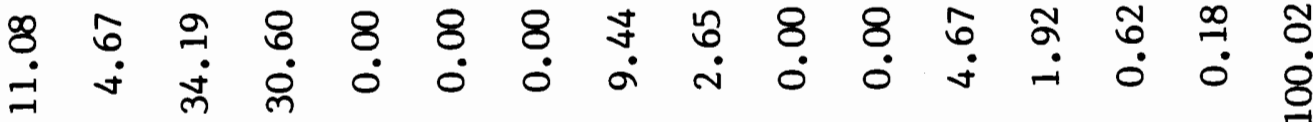

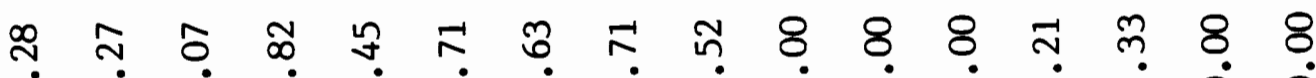

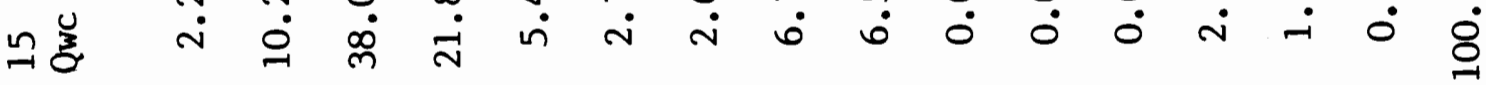

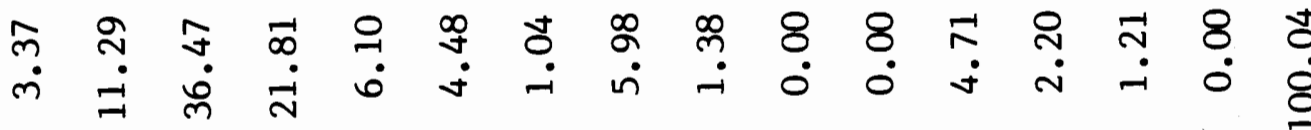

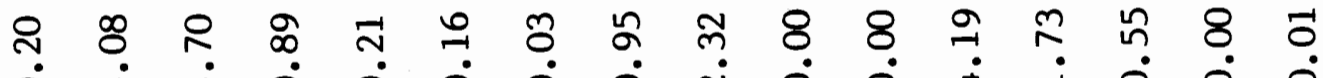

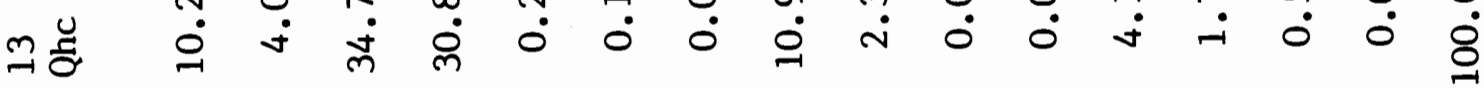

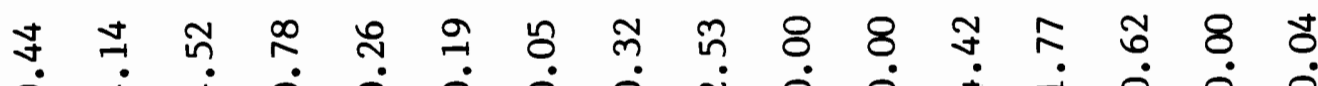

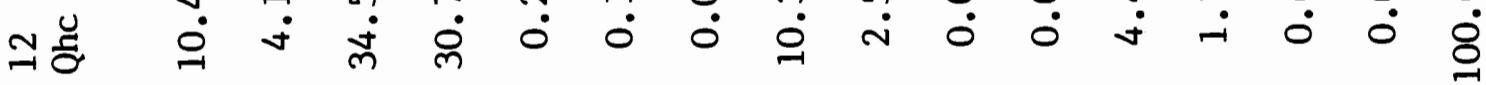
श. $\infty$ ตे กี กิ

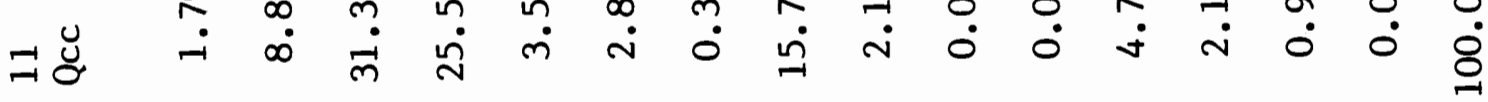

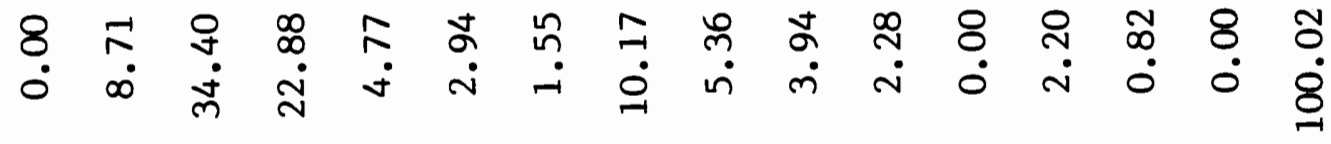

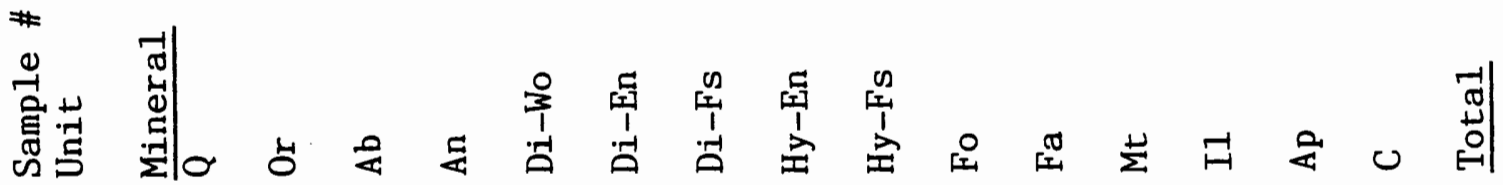


APPENDIX D

Chemical and Normative Analyses, Ohanapecosh Formation and Tertiary Intrusions

$\begin{array}{llllllll}\text { Sample \# } & 16 & 17 & 26 & 27 & 28 & 29 & 30 \\ \text { Unit } & \text { Ti } & \text { Ti } & \text { To } & \text { To } & \text { To } & \text { Ti } & \text { Ti }\end{array}$

Element

SiO 2
Ti0
2
A1 0
23

$\mathrm{Fe} 0$

23

$\mathrm{FeO}$

$\begin{array}{lllllll}58.73 & 60.43 & 53.13 & 51.68 & 54.94 & 64.01 & 56.48\end{array}$

$\mathrm{MnO}$

0.92

0.78

1.25

1.06

1.42

$0.74 \quad 1.19$

$\begin{array}{lllllll}19.25 & 18.42 & 19.67 & 18.92 & 18.18 & 17.94 & 18.02\end{array}$

$\begin{array}{lllllll}2.85 & 2.53 & 4.23 & 4.22 & 4.63 & 2.53 & 4.07\end{array}$

$\mathrm{MgO}$

3.27

$2.90 \quad 4.84$

4.83

5.30

$2.89 \quad 4.67$

0.110 .08

0.15

0.15

0.17

0.09

0.16

$\mathrm{MgO}$
$\mathrm{CaO}$

3.27

3.69

3.75

5.72

3.41

2.66

3.44

7.48

6.14

9.02

10.01

7.32

4.96

7.05

$\mathrm{NaO}$

3.28

3.81

3.06

3.20

3.81

3.71

3.62

K 0

0.65

1.07

0.73

0.05

0.64

$0.34 \quad 1.07$

$\mathrm{P} 0$ 25

$\mathrm{H} \mathrm{O}$

0.19

0.15

$0.17 \quad 0.17$

0.17

0.14

0.25 2

$0.00 \quad 0.00$

$0.00 \quad 0.00$

0.00

0.00

0.00

Tota1 $100.00 \quad 100.00$ 
\begin{tabular}{l} 
Sample \\
Unit \\
Mineral \\
\hline 0
\end{tabular}

Or

$\mathrm{Ab}$

An

Di-Wo

Di-En

Di-Fs

Hy-En

Hy-Fs

Fo

Fa

Mt

I1

Ap

C

Total
16

Ti
$17 \quad 26$

Ti To
27

To
28

To
29

$\mathrm{Ti}$
30

Ti

$\begin{array}{lllllll}15.73 & 14.99 & 7.72 & 4.07 & 9.27 & 25.94 & 10.94\end{array}$

$\begin{array}{lllllll}3.84 & 6.23 & 4.31 & 0.30 & 3.78 & 2.01 & 6.32\end{array}$ $\begin{array}{lllllll}27.75 & 32.21 & 25.89 & 27.08 & 32.24 & 31.39 & 30.63\end{array}$ $\begin{array}{lllllll}35.87 & 29.48 & 37.78 & 37.11 & 30.62 & 23.69 & 29.76\end{array}$ $\begin{array}{lllllll}0.00 & 0.00 & 2.45 & 4.77 & 1.92 & 0.00 & 1.52\end{array}$ $\begin{array}{lllllll}0.00 & 0.00 & 1.63 & 3.41 & 1.23 & 0.00 & 1.00\end{array}$ $\begin{array}{lllllll}0.00 & 0.00 & 0.63 & 0.94 & 0.56 & 0.00 & 0.41\end{array}$ $\begin{array}{lllllll}8.14 & 9.19 & 7.71 & 10.83 & 7.26 & 6.62 & 7.57\end{array}$ $\begin{array}{lllllll}2.34 & 2.10 & 2.98 & 2.97 & 3.32 & 2.16 & 3.13\end{array}$ $\begin{array}{lllllll}0.00 & 0.00 & 0.00 & 0.00 & 0.00 & 0.00 & 0.00\end{array}$ $\begin{array}{lllllll}0.00 & 0.00 & 0.00 & 0.00 & 0.00 & 0.00 & 0.00\end{array}$ $\begin{array}{lllllll}4.13 & 3.67 & 6.13 & 6.12 & 6.71 & 3.67 & 5.90\end{array}$ $\begin{array}{lllllll}1.75 & 1.48 & 2.37 & 2.01 & 2.70 & 1.40 & 2.60\end{array}$ $\begin{array}{lllllll}0.45 & 0.36 & 0.40 & 0.41 & 0.40 & 0.33 & 0.57\end{array}$ $\begin{array}{lllllll}0.01 & 0.19 & 0.00 & 0.00 & 0.00 & 2.79 & 0.00\end{array}$ $\begin{array}{lllllll}100.01 & 99.90 & 100.00 & 100.02 & 100.01 & 100.00 & 100.35\end{array}$ 


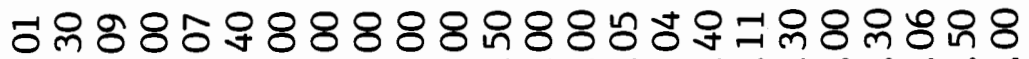

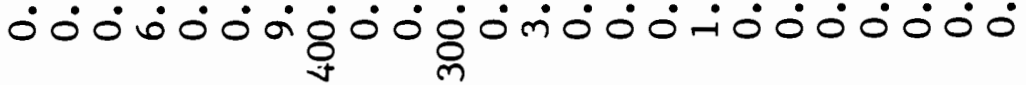

u $\quad+1+1+1+1+1+1+1+1+1+1+1+1+1+1+1+1+1+1+1+1+1+1+1+1$ ๘

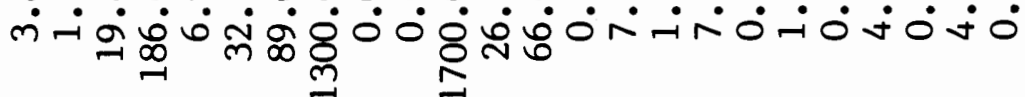

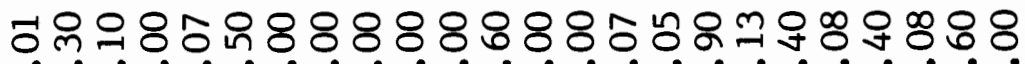

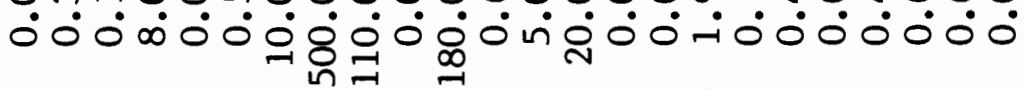

$+1+1+1+1+1+1+1+1+1+1+1+1+1+1+1+1+1+1+1+1+1+1+1+1$

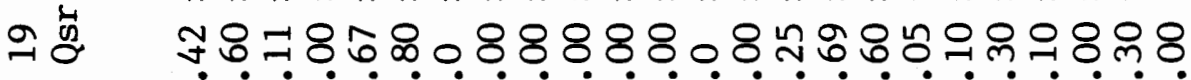

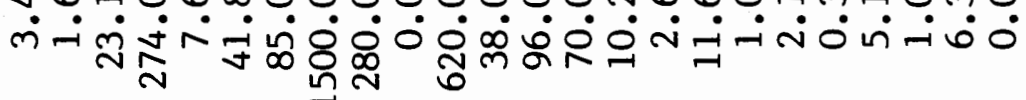

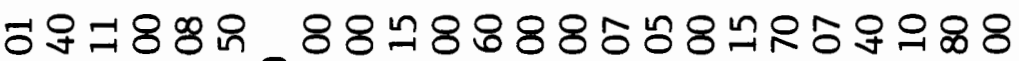

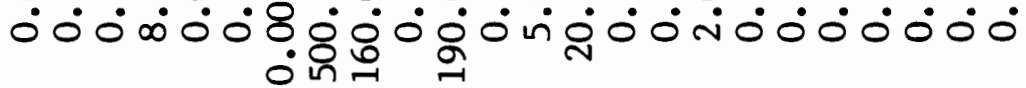
$+1+1+1+1+1+1+1+1+1+1+1+1+1+1+1+1+1+1+1+1+1+1+1+1$ N ڤ⿱艹

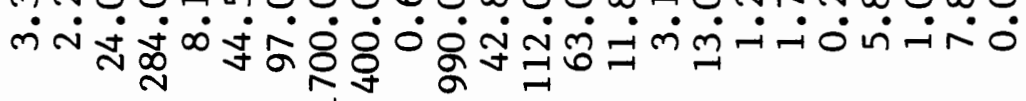

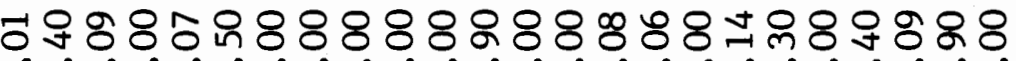

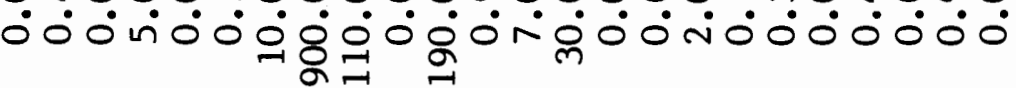

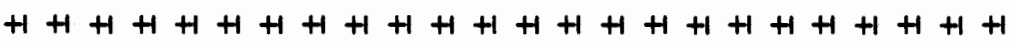

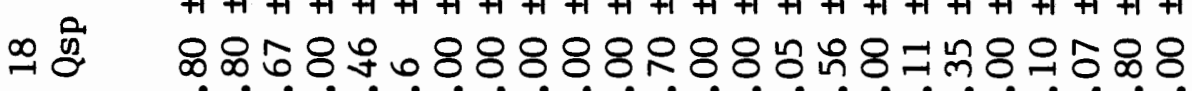
ن

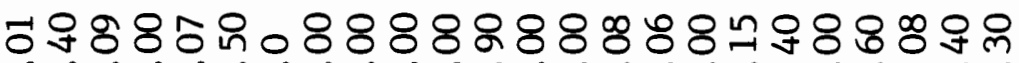

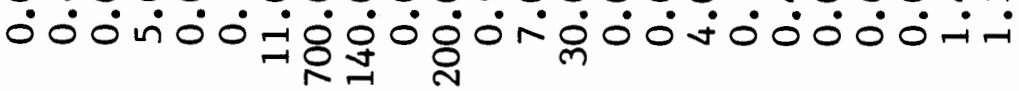
$+1+1+1+1+1+1+1+1+1+1+1+1+1+1+1+1+1+1+1+1+1+1+1+1$ 웡ํำ - के mं

\#

峁

四|

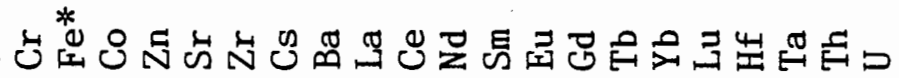




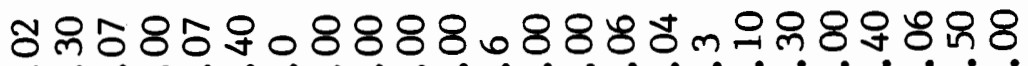

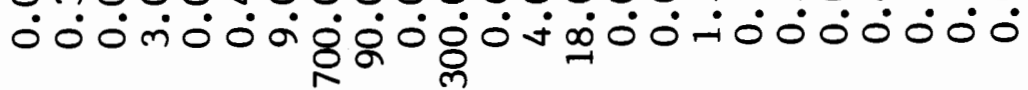

质 $\quad+1+1+1+1+1+1+1+1+1+1+1+1+1+1+1+1+1+1+1+1+1+1$

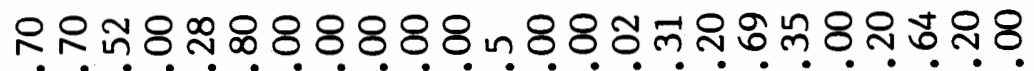

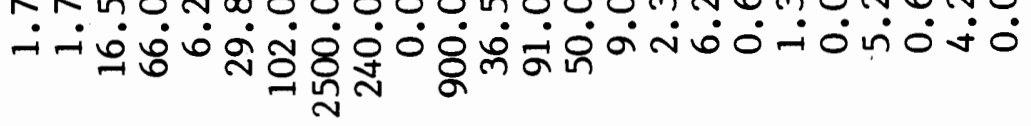

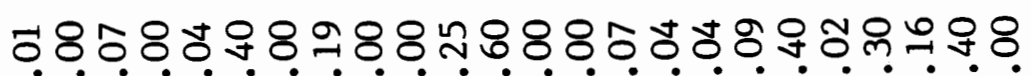

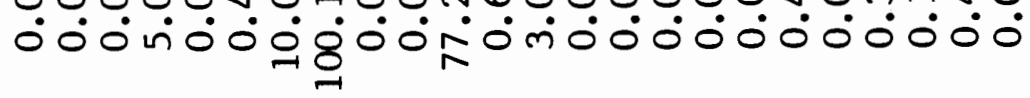

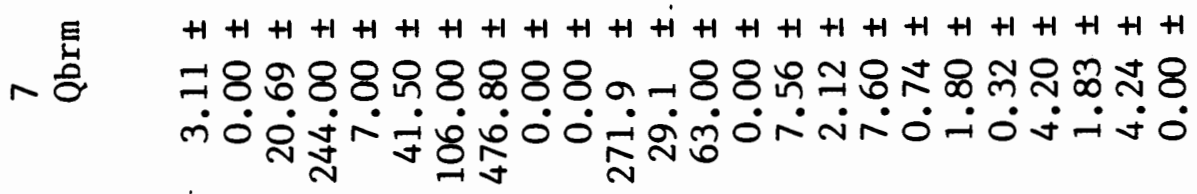

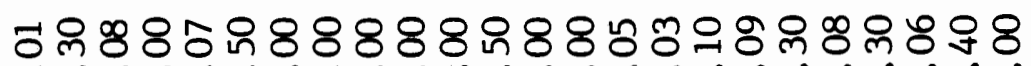

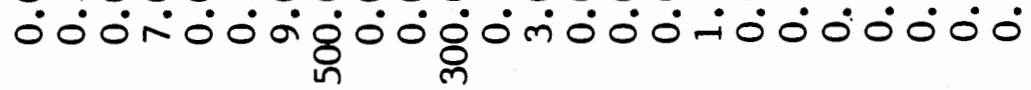

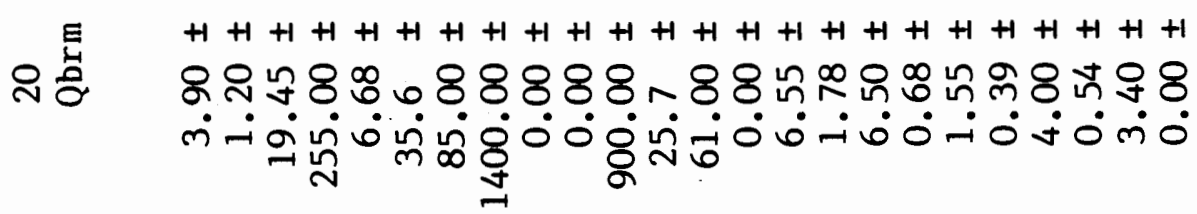

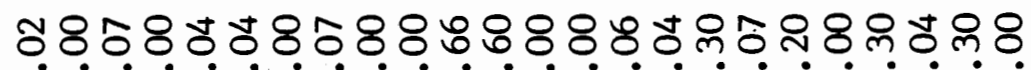

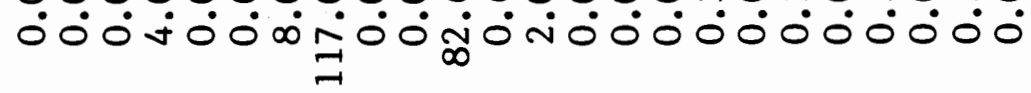

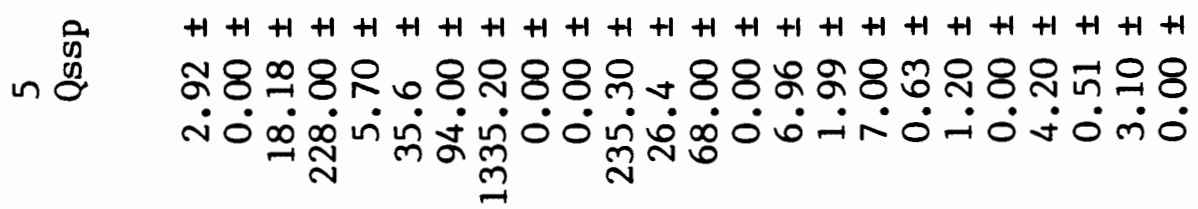

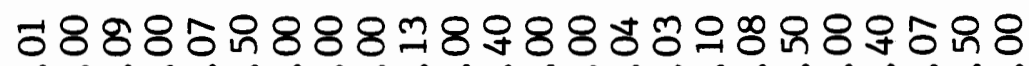

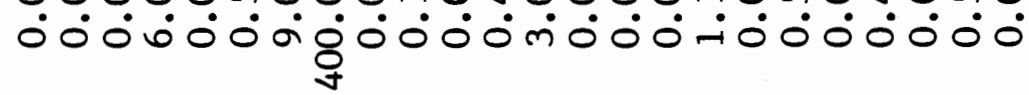
$+1+1+1+1+1+1+1+1+1+1+1+1+1+1+1+1+1+1+1+1+1+1+1+1$

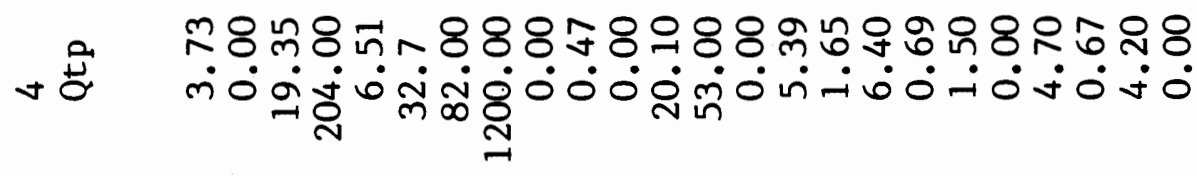

* 


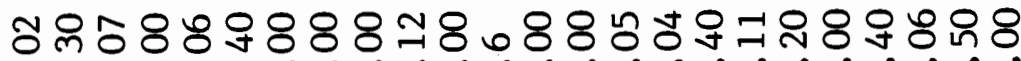

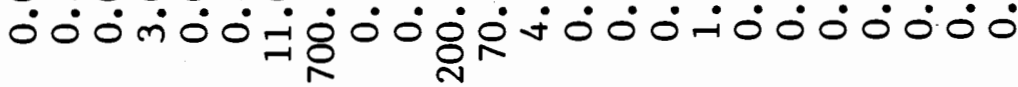

$2 \quad+1+1+1+1+1+1+1+1+1+1+1+1+1+1+1+1+1+1+1+1+1+1+1+1$ สะ รี. ن

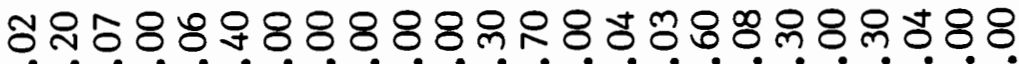

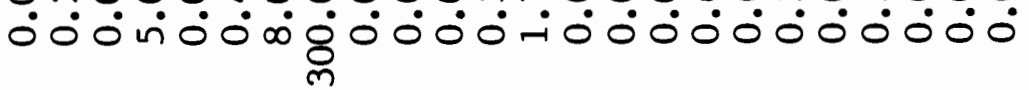

$\quad+1+1+1+1+1+1+1+1+1+1+1+1+1+1+1+1+1+1+1+1+1+1$

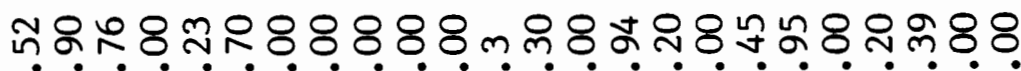

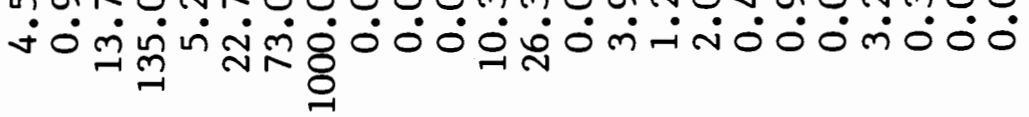

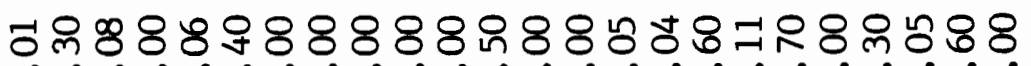

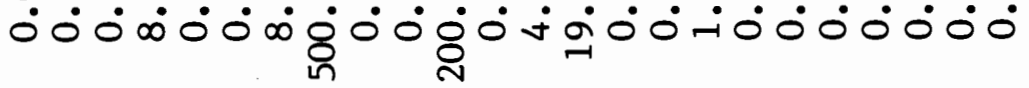
$+1+1+1+1+1+1+1+1+1+1+1+1+1+1+1+1+1+1+1+1+1+1+1+1$ च岁 लं

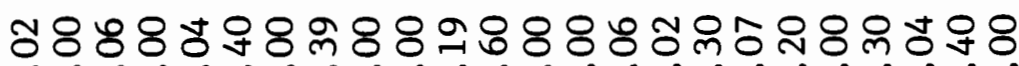

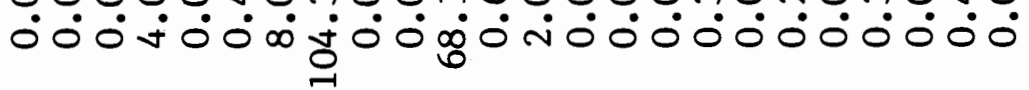

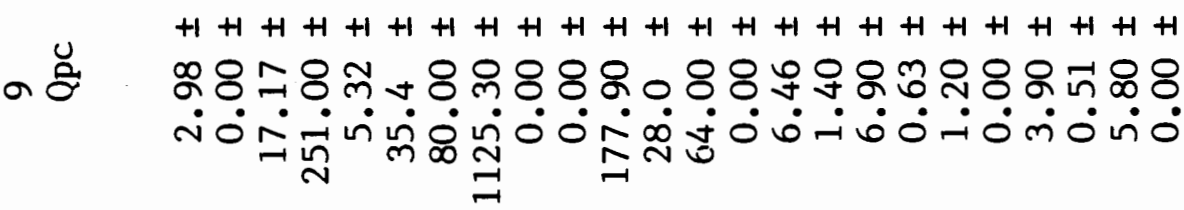

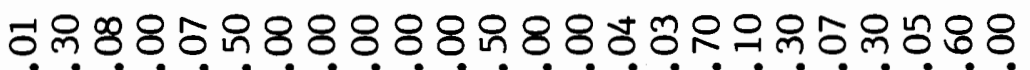

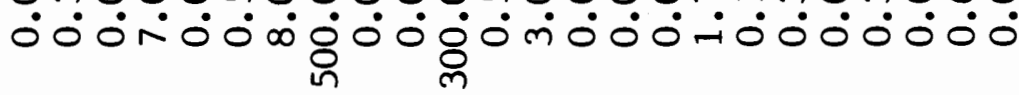

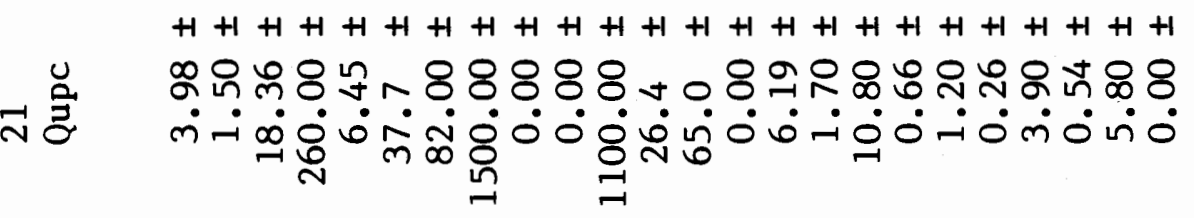

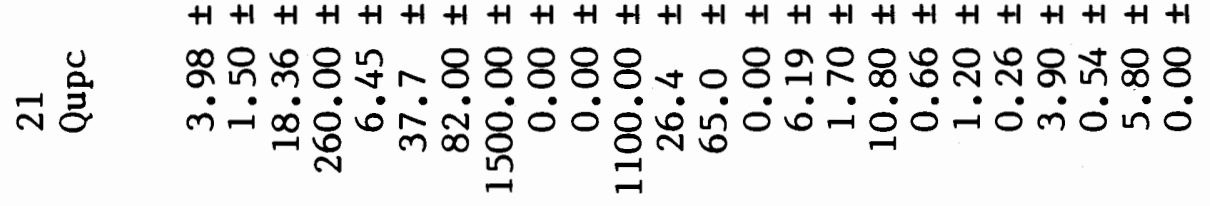
$\frac{\mathbb{2}}{\vec{x}}$ 岕

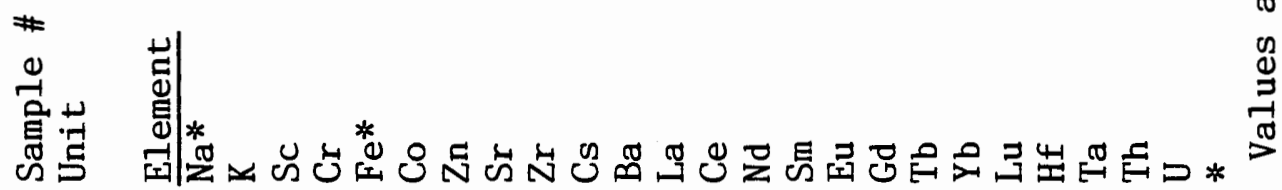




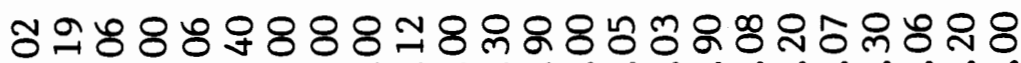

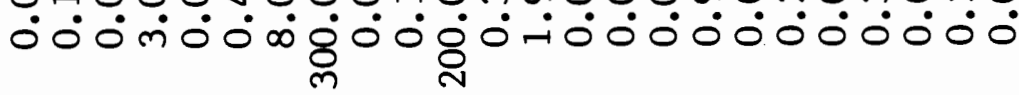

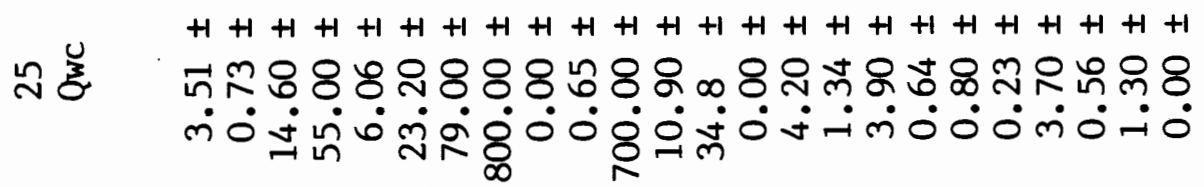

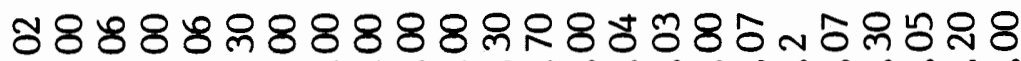
000ंग0ं0

u $\quad+1+1+1+1+1+1+1+1+1+1+1+1+1+1+1+1+1+1+1+1+1+1+1$ N

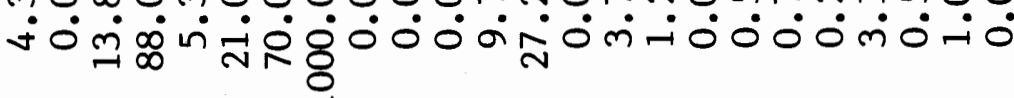

ช

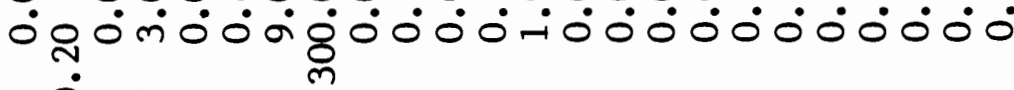
$+1+1+1+1+1+1+1+1+1+1+1+1+1+1+1+1+1+1+1+1+1$

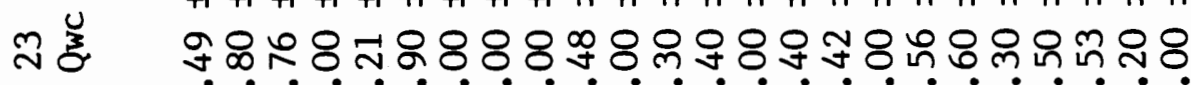

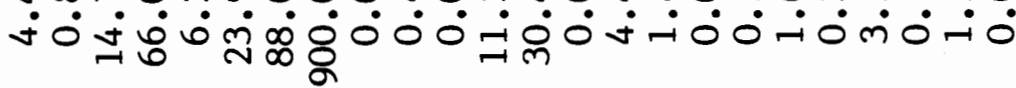

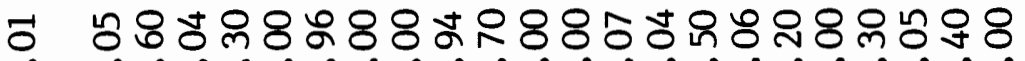

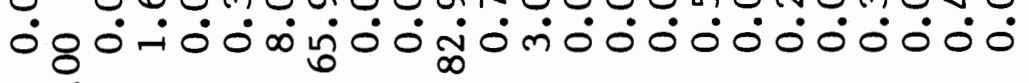
$+1+1+1+1+1+1+1+1+1+1+1+1+1+1+1+1+1+1+1+1+1+1$

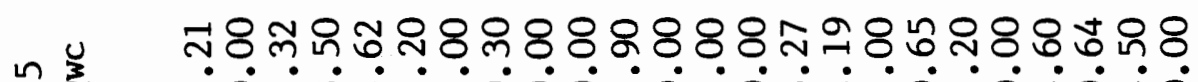

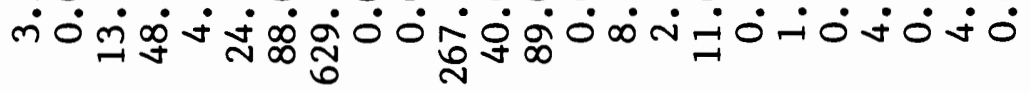

\#

章|

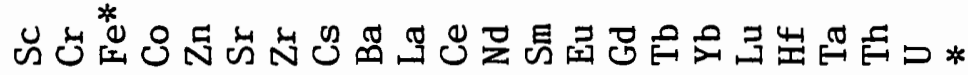




\section{APPENDIX $\mathrm{F}$}

Analytical Proceedures and Errors

Several analytical methods were used to chemically and petrographically analyze the rock samples from the map area. The methods were modal analysis of the mineralogical content by point counting, major element analysis using $\mathrm{x}$-ray fluorescence, and trace element analysis using neutron activation.

The point counting of thin-sections was accomplished using a Zeiss petrographic microscope fitted with a mechanical stage. A total of 1000 points were counted using the Glagolev-Chayes method and recorded on a Swift automatic counter. The number of counts for each mineral was converted to an area percent representing the total volume percent of the mineral in the rock. Possible errors in the modal analysis may be the result of: 1) sampling bias, 2) errors in identification of the mineral grains, and 3) a statistical error. The error resulting from sampling bias and misinterpretation of the mineral grains was minimized by carefully scrutenizing the sample before point counting was undertaken. The statistical error was determined at the 95

percent confidence level using the formula $2 \sqrt{\frac{P(100-P)}{N}}$ where $\mathrm{N}$ is the total number of points counted and $\mathrm{P}$ is the percentage of the individual mineral component (Carver, 1971). 
Major element analyses were done by Peter Hooper at Washington State University using $x$-ray fluorescence. The proceedure used is summarized by Hooper et al. (1981). Approximately 3.5 grams of powdered sample is fused with 7 grams of lithium tetraborate. The bead is then irradiated in a Phillips 1410 spectrometer with a chromium target tube. The counts for each element is compared to the counts of a known standard and corrected for absorption. The results are reported volatile free and with $\mathrm{Fe} 0$ assumed to be 2.00 weight percent. 23

Hooper et al. (1981) lists and discusses several factors which may affect the results reported. The most important factors are: 1)instrumental precision, 2) bias due to different calibration curves, 3) sample inhomogeneity and 4) random errors. The various factors have been analyzed by Hooper and the precision is listed in Table $\mathrm{V}$ at the 95 percent confidence level. It should be noted that $\mathrm{x}$-ray fluorescence is not the most accurated method for the determination of sodium and the results may differ significantly from those of more accurate methods such as neutron activation analysis.

Trace-element analyses were performed by the author using instrumental neutron activation analysis (INAA) at Portland State University. Sixteen grams of powdered sample were split to approximately 1 gram in order to get a well-homogenized fraction. After preparation, the samples were irradiated for one hour in a TRIGA Mark I reactor at Reed College in Portland. The neutron 


\section{TABLE V}

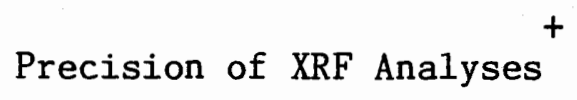

Major Elements

$\mathrm{SiO}$

A1 2

23

$\mathrm{TiO}$

2 *

$\mathrm{Fe} 0$

23

MnO

$\mathrm{CaO}$

$\mathrm{MgO}$

$\mathrm{K} 0$

2

$\mathrm{Na} O$

2

$\mathrm{P} 0$

25
Total Analytical Precision

0.550

0.310

0.050

0.350

0.010

0.220

0.150

0.030

0.160

0.014

$+$

After Hooper et a1.(1981)

Total $\mathrm{Fe}$ as $\mathrm{Fe} 0$

23 
flux at the "lazy-susan" where the samples were placed was $2 \mathrm{x}$ 122

10 neutrons/cm / sec. After irradiation, the samples were allowed to remain in the reactor for 24 hours before being transported to Portland State Universtiy for counting. The counting was done at approximately 10 days and again at 40 days after irradiation using a $\mathrm{Li}-\mathrm{Ge}$ detector. The peaks were determined using a Tracor Northern analyser. The actual traceelement concentrations were determined by the comparative method on a Honeywell computer using the U.S.G.S. basalt standard W-1. Two types of errors may affect the results of INAA, systematic error and random error. Systematic errors include: different neutron fluxes for the standard and the samples, incorrect preparation of the standard, and dead time losses due to different activities of the standard and the samples. Systematic errors were lessened by using the U.S.G.S. prepared standard and subjecting the samples and standard to the same conditions of irradiation and counting. Random errors include statistical error, instrumental changes and contamination or weighing errors. Using the comparative method of concentration calculation, random errors were reduced. The results are reported at the 68 percent confidence level. 